\title{
Oral or transdermal opioids for osteoarthritis of the knee or hip (Review)
}

\author{
Nüesch E, Rutjes AWS, Husni E, Welch V, Jüni P
}

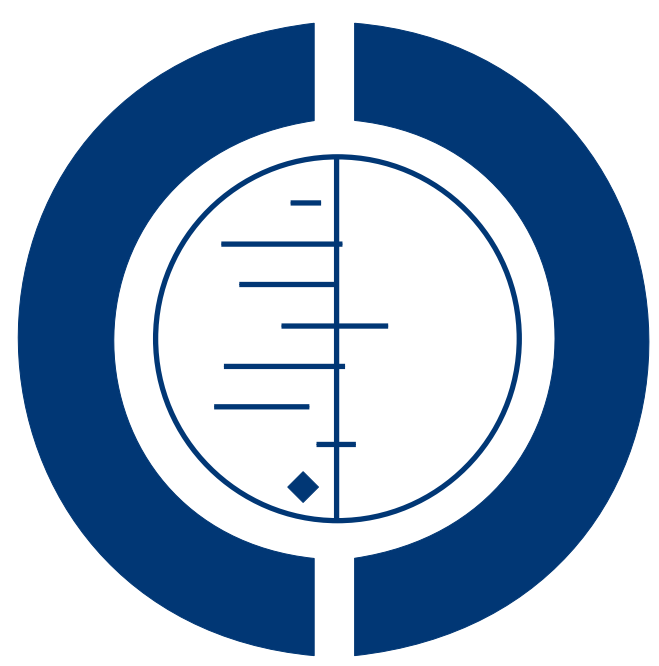

\section{THE COCHRANE COLLABORATION $^{\circledR}$}

This is a reprint of a Cochrane review, prepared and maintained by The Cochrane Collaboration and published in The Cochrane Library 2009, Issue 4

http://www.thecochranelibrary.com

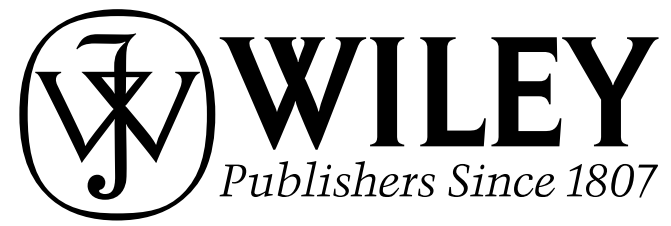

Oral or transdermal opioids for osteoarthritis of the knee or hip (Review)

Copyright (@) 2009 The Cochrane Collaboration. Published by John Wiley \& Sons, Ltd. 
TABLE OF CONTENTS

HEADER . . . . . . . . . . . . . . . . . . . . . . . . . . . . . . . . . . . . . . . 1

ABSTRACT . . . . . . . . . . . . . . . . . . . . . . . . . . . . . . . . . . . . . . . 1

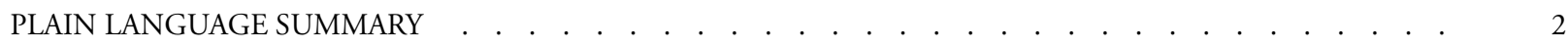

SUMMARY OF FINDINGS FOR THE MAIN COMPARISON . . . . . . . . . . . . . . . . . . . . . . . . 3

BACKGROUND . . . . . . . . . . . . . . . . . . . . . . . . . . . . . . . . . . . . . 7

OBJECTIVES . . . . . . . . . . . . . . . . . . . . . . . . . . . . . . . . . . . . . 47

METHODS . . . . . . . . . . . . . . . . . . . . . . . . . . . . . . . . . . . . . . 7

Figure 1. . . . . . . . . . . . . . . . . . . . . . . . . . . . . . . . . . . . . . 9

RESULTS . . . . . . . . . . . . . . . . . . . . . . . . . . . . . . . . . . . 11

Figure 2. . . . . . . . . . . . . . . . . . . . . . . . . . . . . . . . . . . . . . 13

Figure 3. . . . . . . . . . . . . . . . . . . . . . . . . . . . . . . . . . . . . . 15

Figure 4. . . . . . . . . . . . . . . . . . . . . . . . . . . . . . . . . . . . . . 16

Figure 5. . . . . . . . . . . . . . . . . . . . . . . . . . . . . . . . . . 17

Figure 6. . . . . . . . . . . . . . . . . . . . . . . . . . . . . . . . . . . . . . 20

Figure $7 . \quad$. . . . . . . . . . . . . . . . . . . . . . . . . . . . . . . . . . . . . 21

Figure 8. . . . . . . . . . . . . . . . . . . . . . . . . . . . . . . . . . . . . . 22

Figure 9. . . . . . . . . . . . . . . . . . . . . . . . . . . . . . . . . . . 25

Figure 10. . . . . . . . . . . . . . . . . . . . . . . . . . . . . . . . . . . . . . 27

Figure 11. . . . . . . . . . . . . . . . . . . . . . . . . . . . . . . . . . . . . . 28

Figure 12. . . . . . . . . . . . . . . . . . . . . . . . . . . . . . . . . . . . . . 29

DISCUSSION .. . . . . . . . . . . . . . . . . . . . . . . . . . . . . . . . . . . . 30

AUTHORS' CONCLUSIONS . . . . . . . . . . . . . . . . . . . . . . . . . . . . . . . . . . . . . 30

ACKNOWLEDGEMENTS . . . . . . . . . . . . . . . . . . . . . . . . . . . . . . . . . . . . . . . . . 31

REFERENCES . . . . . . . . . . . . . . . . . . . . . . . . . . . . . . . . . . . . . 31

CHARACTERISTICS OF STUDIES . . . . . . . . . . . . . . . . . . . . . . . . . . . . . . . . . . .

DATA AND ANALYSES . . . . . . . . . . . . . . . . . . . . . . . . . . . . . . . . . . . . . . . . . . . 52

Analysis 1.1. Comparison 1 Opioids versus placebo, Outcome 1 Pain. . . . . . . . . . . . . . . . . . . . 53

Analysis 1.2. Comparison 1 Opioids versus placebo, Outcome 2 Function. . . . . . . . . . . . . . . . . . . . 54

Analysis 1.3. Comparison 1 Opioids versus placebo, Outcome 3 Number of patients experiencing any adverse event. 55

Analysis 1.4. Comparison 1 Opioids versus placebo, Outcome 4 Number of patients who withdrew because of adverse events.

Analysis 1.5. Comparison 1 Opioids versus placebo, Outcome 5 Number of patients experiencing any serious adverse event. . . . . . . . . . . . . . . . . . . . . . . . . . . . . . . . 57

Analysis 1.6. Comparison 1 Opioids versus placebo, Outcome 6 Withdrawal symptoms. . . . . . . . . . . . 58 APPENDICES . . . . . . . . . . . . . . . . . . . . . . . . . . . . . . . . . . . . . 58

WHAT'S NEW . . . . . . . . . . . . . . . . . . . . . . . . . . . . . . . . . . . . . 63

HISTORY . . . . . . . . . . . . . . . . . . . . . . . . . . . . . . . . . . . . . . . 63

CONTRIBUTIONS OF AUTHORS . . . . . . . . . . . . . . . . . . . . . . . . . . . . . . . . . . . . . 64

DECLARATIONS OF INTEREST . . . . . . . . . . . . . . . . . . . . . . . . . . . . . . . . . . . . 64

SOURCES OF SUPPORT . . . . . . . . . . . . . . . . . . . . . . . . . . . . . . . . . . . . . . . . . . . . 64

DIFFERENCES BETWEEN PROTOCOL AND REVIEW . . . . . . . . . . . . . . . . . . . . . . . . . . 64

Oral or transdermal opioids for osteoarthritis of the knee or hip (Review)

Copyright ( 2009 The Cochrane Collaboration. Published by John Wiley \& Sons, Ltd. 


\section{Oral or transdermal opioids for osteoarthritis of the knee or hip}

Eveline Nüesch ${ }^{1}$, Anne WS Rutjes $^{1}$, Elaine Husni ${ }^{2}$, Vivian Welch $^{3}$, Peter Jüni ${ }^{1}$

${ }^{1}$ Division of Clinical Epidemiology and Biostatistics, Institute of Social and Preventive Medicine, University of Bern, Bern, Switzerland. ${ }^{2}$ Department of Rheumatic and Immunologic Diseases, Cleveland Clinic: Orthopedic and Rheumatologic Institute, $\mathrm{Cleveland}, \mathrm{OH}$, USA. ${ }^{3}$ Centre for Global Health, Institute of Population Health, University of Ottawa, Ottawa, Canada

Contact address: Eveline Nüesch, Division of Clinical Epidemiology and Biostatistics, Institute of Social and Preventive Medicine, University of Bern, Finkenhubelweg 11, Bern, 3012, Switzerland. enueesch@ispm.unibe.ch. (Editorial group: Cochrane Musculoskeletal Group.)

Cochrane Database of Systematic Reviews, Issue 4, 2009 (Status in this issue: New)

Copyright (C 2009 The Cochrane Collaboration. Published by John Wiley \& Sons, Ltd.

DOI: $10.1002 / 14651858 . C D 003115 . p u b 3$

This version first published online: 7 October 2009 in Issue 4, 2009.

Last assessed as up-to-date: 12 May 2008. (Help document - Dates and Statuses explained)

This record should be cited as: Nüesch E, Rutjes AWS, Husni E, Welch V, Jüni P. Oral or transdermal opioids for osteoarthritis of the knee or hip. Cochrane Database of Systematic Reviews 2009, Issue 4. Art. No.: CD003115. DOI: 10.1002/14651858.CD003115.pub3.

\section{A B S T R A C T}

\section{Background}

Osteoarthritis is the most common form of joint disease and the leading cause of pain and physical disability in the elderly. Opioids may be a viable treatment option if patients suffer from severe pain or if other analgesics are contraindicated. However, the evidence about their effectiveness and safety is contradictory.

\section{Objectives}

To determine the effects on pain and function and the safety of oral or transdermal opioids as compared with placebo or no intervention in patients with osteoarthritis of the hip or knee.

\section{Search strategy}

We searched CENTRAL, MEDLINE, EMBASE, and CINAHL (up to 28 July 2008), checked conference proceedings, reference lists, and contacted authors.

\section{Selection criteria}

Studies were included if they were randomised or quasi-randomised controlled trials that compared oral or transdermal opioids with placebo or no treatment in patients with osteoarthritis of the knee or hip. Studies of tramadol were excluded. No language restrictions were applied.

\section{Data collection and analysis}

We extracted data in duplicate. Standardised mean differences (SMDs) and 95\% confidence intervals (CI) were calculated for pain and function, and risk ratios for safety outcomes. Trials were combined using inverse-variance random-effects meta-analysis.

\section{Main results}

Ten trials with 2268 participants were included. Oral codeine was studied in three trials, transdermal fentanyl and oral morphine in one trial each, oral oxycodone in four, and oral oxymorphone in two trials. Overall, opioids were more effective than control interventions 
in terms of pain relief (SMD - $0.36,95 \%$ CI -0.47 to -0.26) and improvement of function (SMD - $0.33,95 \%$ CI -0.45 to -0.21 ). We did not find substantial differences in effects according to type of opioid, analgesic potency (strong or weak), daily dose, duration of treatment or follow up, methodological quality of trials, and type of funding. Adverse events were more frequent in patients receiving opioids compared to control. The pooled risk ratio was 1.55 (95\% CI 1.41 to 1.70$)$ for any adverse event ( 4 trials), 4.05 ( $95 \%$ CI 3.06 to 5.38) for dropouts due to adverse events ( 10 trials), and 3.35 ( $95 \%$ CI 0.83 to 13.56) for serious adverse events ( 2 trials). Withdrawal symptoms were more severe after fentanyl treatment compared to placebo (SMD 0.60, 95\% CI 0.42 to $0.79 ; 1$ trial).

\section{Authors' conclusions}

The small to moderate beneficial effects of non-tramadol opioids are outweighed by large increases in the risk of adverse events. Nontramadol opioids should therefore not be routinely used, even if osteoarthritic pain is severe.

\section{PLAIN LANGUAGE SUMMARY}

\section{Opioids for osteoarthritis}

This summary of a Cochrane review presents what we know from research about the effect of opioids on osteoarthritis.

\section{The review shows that in people with osteoarthritis:}

- Opioids moderately improve pain or physical function.

- Opioids probably cause side effects. However, we do not have precise information about rare but serious side effects.

\section{What is osteoarthritis and what are opioids?}

Osteoarthritis (OA) is a disease of the joints, such as your knee or hip. When the joint loses cartilage, the bone grows to try and repair the damage. Instead of making things better, however, the bone grows abnormally and makes things worse. For example, the bone can become misshapen and make the joint painful and unstable. This can affect your physical function or ability to use your knee.

Opioids are powerful pain-relieving substances that are used for the pain of cancer or osteoarthritis. Some examples of opioids are codeine-containing Tylenol ${ }^{\circledR}(1,2,3$ and 4), hydromorphone (Dilaudid), oxycodone (Percocet, Percodan), morphine and others. They can be taken in a pill form, as an injection, or as a patch placed on the painful area.

\section{Best estimate of what happens to people with osteoarthritis who take Opioids}

Pain

- People who took opioids rated improvement in their pain to be about 3 on a scale of 0 (no pain) to 10 (extreme pain) after 1 month.

- People who took a placebo rated improvement in their pain to be about 2 on a scale of 0 (no pain) to 10 (extreme pain) after 1 month. Another way of saying this is:

- 35 people out of 100 who use opioids respond to treatment (35\%).

- 31 people out of 100 who use placebo respond to treatment (31\%).

-4 more people respond to treatment with opioids than with placebo (difference of $4 \%$ ).

\section{Physical Function}

- People who took opioids rated improvement in their physical function to be about 2 on a scale of 0 (no disability) to 10 (extreme disability) after 1 month.

- People who took a placebo rated improvement in their physical function to be about 1 on a scale of 0 (no disability) to 10 (extreme disability) after 1 month. 
Another way of saying this is:

- 29 people out of 100 who use opioids respond to treatment (29\%).

- 26 people out of 100 who use placebo respond to treatment (26\%).

- 3 more people respond to treatment with opioids than with placebo (difference of $3 \%$ ).

\section{Side effects}

- 23 people out of 100 who used opioids experienced side effects (23\%).

- 15 people out of 100 who used a placebo experienced side effects (15\%).

- 7 more people experienced side effects with opioids than with placebo (difference of 7\%). 
SUMMARY OF FINDINGS FOR THE MAIN COMPARISONE [Explanation]

Oral or transdermal opioids compared with placebo for osteoarthritis of the knee or hip

Patient or population: Patients with osteoarthritis of the knee or hip

Settings: Various orthopedic or rheumatology clinics

Intervention: Oral or transdermal opioids

Comparison: Placebo

\begin{tabular}{|c|c|c|c|c|c|c|}
\hline \multirow[t]{3}{*}{ Outcomes } & \multicolumn{2}{|c|}{ Illustrative comparative risks* $(95 \% \mathrm{CI})$} & \multirow{3}{*}{$\begin{array}{l}\text { Relative effect } \\
(95 \% \text { CI) }\end{array}$} & \multirow{3}{*}{$\begin{array}{l}\text { No of Participants } \\
\text { (studies) }\end{array}$} & \multirow{3}{*}{$\begin{array}{l}\text { Quality of the evidence } \\
\text { (GRADE) }\end{array}$} & \multirow[t]{3}{*}{ Comments } \\
\hline & Assumed risk & Corresponding risk & & & & \\
\hline & Placebo & Opioids & & & & \\
\hline $\begin{array}{l}\text { Pain intensity } \\
\text { Various pain scales. } \\
\text { (median follow-up: } 4 \\
\text { weeks) }\end{array}$ & $\begin{array}{l}-1.8 \mathrm{~cm} \text { change } \\
\text { on } 10 \mathrm{~cm} \text { VAS }^{1} \\
29 \% \text { improvement }\end{array}$ & $\begin{array}{l}-\mathbf{- 2 . 7} \mathrm{cm} \text { change } \\
(\Delta-0.9 \mathrm{~cm},-1.2 \text { to }-0.7)^{2} \\
\mathbf{4 4 \%} \text { improvement } \\
(\Delta 15 \%, 11 \% \text { to } 20 \%)^{3}\end{array}$ & SMD $-0.36(-0.47$ to -0.26$)$ & $\begin{array}{l}2268 \\
(10)\end{array}$ & $\begin{array}{l}++++ \\
\text { high }\end{array}$ & NNT: $25(95 \% \mathrm{Cl} 19 \text { to } 34)^{4}$ \\
\hline $\begin{array}{l}\text { Function } \\
\text { Various validated function } \\
\text { scales. } \\
\text { (median follow-up: } 4 \\
\text { weeks) }\end{array}$ & $\begin{array}{l}-1.2 \text { units } \\
\text { on WOMAC (range } 0 \text { to } \\
10)^{1} \\
21 \% \text { improvement }\end{array}$ & $\begin{array}{l}-1.9 \text { units on WOMAC } \\
(\Delta-0.7,-1.0 \text { to }-0.5)^{5} \\
\mathbf{3 4 \%} \text { improvement } \\
(\Delta 13 \%, 9 \% \text { to } 18 \%)^{6}\end{array}$ & SMD $-0.33(-0.45$ to -0.21$)$ & $\begin{array}{l}1794 \\
(7)\end{array}$ & $\begin{array}{l}++++ \\
\text { high }\end{array}$ & NNT: $30(95 \% \mathrm{Cl} 22 \text { to } 46)^{7}$ \\
\hline $\begin{array}{l}\text { Number of patients ex- } \\
\text { periencing any adverse }\end{array}$ & $\begin{array}{l}150 \text { per } 1000 \text { patient- } \\
\text { years }^{8}\end{array}$ & $\begin{array}{l}233 \text { per } 1000 \text { patient-years } \\
\text { (212 to } 255)\end{array}$ & RR 1.55 (1.41 to 1.70$)$ & $\begin{array}{l}1080 \\
(4)\end{array}$ & $\begin{array}{l}+++0 \\
\text { moderate } 9\end{array}$ & NNH: $12(95 \% \mathrm{Cl} 10$ to 16$)$ \\
\hline
\end{tabular}

periencing any adverse years ${ }^{\circ}$

(median follow-up: 4

weeks)

Number of patients who 17 per 1000 patient-years $^{8} 69$ per 1000 patient-years

withdrew because of ad-

(52 to 91)

RR 4.05 (3.06 to 5.38)

2403

verse events

(10)

$++++$

high

NNH: 19 (95\% Cl 13 to 29)

(median follow-up: 4

weeks) 


\begin{tabular}{|c|c|c|c|c|c|c|}
\hline $\begin{array}{l}\text { Number of patients expe- } \\
\text { riencing any serious ad- } \\
\text { verse event } \\
\text { (median follow-up: } 4 \\
\text { weeks) }\end{array}$ & 4 per 1000 patient-years ${ }^{8}$ & $\begin{array}{l}13 \text { per } 1000 \text { patient-years } \\
\text { ( } 3 \text { to } 54 \text { ) }\end{array}$ & RR 3.35 (0.83 to 13.56$)$ & $\begin{array}{l}681 \\
(3)\end{array}$ & $\begin{array}{l}++00 \\
\text { low }\end{array}$ & $\begin{array}{l}\text { Little evidence of harmful } \\
\text { effect [NNH: not statisti- } \\
\text { cally significant]. }\end{array}$ \\
\hline $\begin{array}{l}\text { Withdrawal symptoms } \\
\text { Short Opiate Withdrawal } \\
\text { Scale. } \\
\text { (follow-up: } 8 \text { weeks) }\end{array}$ & $\begin{array}{l}0.9 \text { units } \\
\text { (range } 0 \text { to } 3 \text { ) }\end{array}$ & $\begin{array}{l}0.7 \text { units } \\
(\Delta 0.3,0.2 \text { to } 0.4) \\
\mathbf{6 9 \%} \text { increase } \\
(46 \text { to } 92 \%)^{11}\end{array}$ & SMD 0.60 (0.42 to 0.79$)$ & $\begin{array}{l}499 \\
(1)\end{array}$ & $\begin{array}{l}++00 \\
\text { low }^{12}\end{array}$ & $\begin{array}{l}\text { No evidence-based as- } \\
\text { sumption could be made } \\
\text { for the calculation of NNH. }\end{array}$ \\
\hline
\end{tabular}

*The basis for the assumed risk (e.g. the median control group risk across studies) is provided in footnotes. The corresponding risk (and its $95 \%$ confidence interval) is based on the assumed risk in the comparison group and the relative effect of the intervention (and its $95 \% \mathrm{CI}$ ).

Cl: Confidence interval; RR: Risk ratio; SMD: Standardised mean difference; GRADE: GRADE Working Group grades of evidence (see explanations); NNT: number needed to treat; NNH: number needed to harm.

GRADE Working Group grades of evidence

High quality $(++++)$ : Further research is very unlikely to change our confidence in the estimate of effect.

Moderate quality $(+++0)$ : Further research is likely to have an important impact on our confidence in the estimate of effect and may change the estimate.

Low quality $(++\mathbf{0 0})$ : Further research is very likely to have an important impact on our confidence in the estimate of effect and is likely to change the estimate.

Very low quality $(\mathbf{+ 0 0 0 )}$ : We are very uncertain about the estimate.

${ }^{1}$ Median reduction as observed across placebo groups in large osteoarthritis trials (see methods section, Nüesch 2009).

${ }^{2}$ Standardised mean differences (SMDs) were back-transformed onto a $10 \mathrm{~cm}$ visual analogue scale (VAS) on the basis of a typical pooled SD of $2.5 \mathrm{~cm}$ in large trials that assessed pain using a VAS and expressed as change based on an assumed standardised reduction of 0.72 standard deviation units in the control group.

${ }^{3}$ Percentage of improvement was calculated based on median observed pain at baseline across control groups of large osteoarthritis trials of $6.1 \mathrm{~cm}$ on $10 \mathrm{~cm}$ VAS (Nüesch 2009).

${ }^{4}$ Absolute response risks for pain in the control groups were assumed $31 \%$ (see methods section).

${ }^{5}$ Standardised mean differences (SMDs) were back-transformed onto a standardised WOMAC disability score ranging from 0 to 10 on the basis of a typical pooled SD of 2.1 in trials that assessed function using WOMAC disability scores and expressed as change based on an assumed standardised reduction of 0.58 standard deviation units in the control group.

${ }^{6}$ Percentage of improvement was calculated based on median observed WOMAC function scores at baseline across control groups of large osteoarthritis trials of 5.6 units (Nüesch 2009). 
${ }^{7}$ Absolute response risks for function in the control groups were assumed $26 \%$ (see methods section).

Median control risk across placebo groups in large osteoarthritis trials (see methods section, Nüesch 2009).

Downgraded (1 level) because: 4 out of 10 studies reported this outcome, possibly leading to selective outcome reporting bias.

${ }^{10}$ Downgraded (2 levels) because: 3 out of 10 studies reported this outcome, possibly leading to selective outcome reporting bias, the confidence interval of the pooled estimate is wide and crossed no difference.

Percentage of improvement was calculated based on observed withdrawal symptom scores in the placebo group of 0.39 .

${ }^{12}$ Downgraded (2 levels) because the outcome was assessed by a single trial assessing transdermal fentanyl therapy, and 8 weeks

follow-up duration considered short for this outcome. 


\section{B A C K G R O U N D}

Osteoarthritis is the most common form of joint disease and the leading cause of pain and physical disability in the elderly (Altman 1986). It is characterised by focal areas of loss of articular cartilage in synovial joints accompanied by subchondral bone changes, osteophyte formation at the joint margins, thickening of the joint capsule and mild synovitis. Pharmacologic therapy for osteoarthritis, as an alternative or in addition to other therapeutic options, consists mainly of analgesics and nonsteroidal anti-inï $\neg$,ammatory drugs (NSAIDs). However, paracetamol may be inadequate to treat more severe, long-term pain in osteoarthritis and chronic NSAID use may cause serious gastrointestinal and cardiovascular adverse events. Opioids could be a viable alternative if patients suffer from severe pain with insufficient response to conventional treatment or if other analgesics are contraindicated (Avouac 2007).

Opioids are potent analgesics that work by targeting mainly spinal and supraspinal opioid receptors. In addition, cellular studies suggest that there are peripheral opioid receptors in inflamed osteoarthritic synovial tissue, which may mediate analgesic effects ( Stein 1996). The American College of Rheumatology guidelines on management of osteoarthritis, updated in 2000, suggest that opioids can be used as a last resort in osteoarthritis (ACR OA 2000). English guidelines propose opioids as an alternative if inadequate pain relief is achieved with an NSAID or paracetamol (Eccles 1998). However, the use of strong opioids for the treatment of non-cancer pain remains controversial. Concerns have been expressed about long-term use of opioids for chronic noncancer pain mainly due to the risks of addiction (Von Korff 2004; Zhang 2008).

\section{O B JECTIVES}

We set out to compare oral or transdermal opioids with placebo or a non-intervention control in terms of effects on pain and function, safety, and addiction in patients with knee or hip osteoarthritis $(\mathrm{OA})$; and to explore whether potential variation between trials could be explained by type of opioid, route of administration, biases affecting individual trials, or publication bias.

\section{METHODS}

\section{Criteria for considering studies for this review}

\section{Types of studies}

Randomised or quasi-randomised controlled trials with a control group receiving placebo or no intervention.

\section{Types of participants}

At least $75 \%$ of patients with clinically or radiologically confirmed osteoarthritis of the knee or hip. Trials exclusively including patients with inflammatory arthritis, such as rheumatoid arthritis, were not considered.

\section{Types of interventions}

Any type of opioid except tramadol, which is covered in a separate Cochrane Review (Cepeda 2006).

\section{Types of outcome measures}

\section{Primary outcomes}

The main outcomes were pain and function, as currently recommended for osteoarthritis trials (Altman 1996; Pham 2004). If data on more than one pain scale were provided for a trial, we referred to a previously described hierarchy of pain-related outcomes (Jüni 2006; Reichenbach 2007) and extracted data on the pain scale that was highest on this list:

1. global pain;

2. pain on walking;

3. WOMAC osteoarthritis index pain subscore;

4. composite pain scores other than WOMAC;

5. pain on activities other than walking;

6. rest pain or pain during the night;

7. WOMAC global algofunctional score;

8. Lequesne osteoarthritis index global score;

9. other algofunctional scale;

10. patient's global assessment;

11. physician's global assessment.

If data on more than one function scale were provided for a trial, we extracted data according to the hierarchy:

1. global disability score;

2. walking disability;

3. WOMAC disability subscore;

4. composite disability scores other than WOMAC;

5. disability other than walking;

6. WOMAC global scale;

7. Lequesne osteoarthritis index global score;

8. other algofunctional scale;

9. patient's global assessment;

10. physician's global assessment.

If pain or function outcomes were reported at several time points, we extracted the measure at the end of the treatment period.

\section{Secondary outcomes}

Secondary outcomes were the number of patients experiencing any adverse event, patients who withdrew because of adverse events, patients experiencing any serious adverse events, and patients experiencing symptoms of opioid dependence such as craving or physical withdrawal symptoms. Serious adverse events were defined as events resulting in hospitalisation, prolongation of hospitalisation, persistent or significant disability, congenital abnormality or birth defect of offspring, life-threatening events, or death. 


\section{Search methods for identification of studies}

\section{Electronic searches}

We searched the electronic databases CENTRAL (The Cochrane Library) (http://mrw.interscience.wiley.com/cochrane/), MEDLINE and EMBASE through the Ovid platform (www.ovid.com), and CINAHL through EBSCOhost (all from implementation to July 28 2008) using truncated variations of preparation names including brand names combined with truncated variations of terms related to osteoarthritis, all as text words. A validated methodologic filter for controlled clinical trials was applied (Dickersin 1994). The specific search algorithms are displayed in Appendix 1 and Appendix 2.

\section{Searching other sources}

We manually searched conference proceedings, used Science Citation Index to retrieve reports citing relevant articles, contacted content experts and trialists, and screened reference lists of all obtained articles. Finally, we searched several clinical trial registries (www.clinicaltrials.gov, www.controlled-trials.com, www.actr.org.au, www.umin.ac.jp/ctr) to identify ongoing trials. The last update of the manual search was on July 28, 2008.

\section{Data collection and analysis}

\section{Selection of studies}

Two review authors independently evaluated all titles and abstracts for eligibility (EN, AR) (see Figure 1). Disagreements were resolved by discussion. No language restrictions were applied. If multiple reports described the same trial, we considered all. 
Figure I. Study flow chart

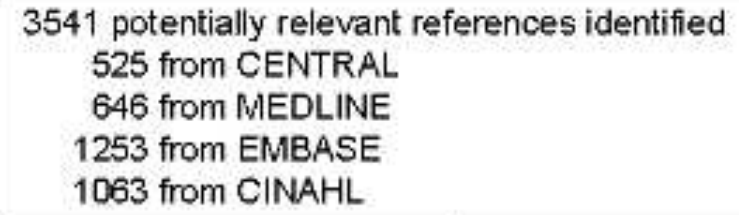

2563 potentially relevant references screened

2484 reports excluded for further review

744 post-operative pain

565 reviews, editorials or commentaries

554 not relevant to osteoarthritis

442 not relevant for specified opioids

128 non-randomised trials in humans

50 conference proceedings / abstracts

1 no relevant outcome

79 potentially relevant references retrieved

for more detailed assessments

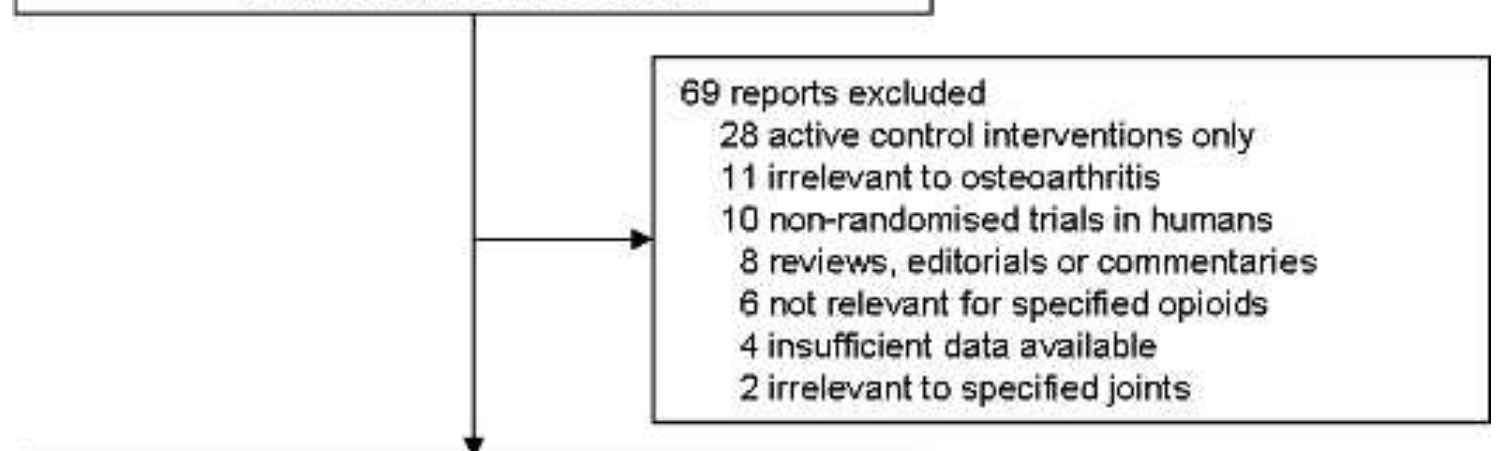

10 reports included in meta-analysis

10 RCTs included in meta-analysis 


\section{Data collection}

Two review authors (EN, AR) extracted trial information independently using a standardised, piloted extraction form accompanied by a codebook. Disagreements were resolved by discussion. We extracted both the generic and trade name of the experimental intervention, the type of control used, dosage, frequency, route of administration, duration of treatment, patient characteristics (gender, average age and duration of symptoms, types of joints affected), types of measures used and pain and function-related outcomes, trial design, trial size, duration of follow up, type and source of financial support, and publication status. When necessary, means and measures of dispersion were approximated from figures in the reports. For crossover trials, we extracted data from the first period only. Whenever possible, we used results from an intention-to-treat analysis. If effect sizes could not be calculated, we contacted the authors for additional data.

\section{Quality assessment}

Two review authors (EN, AR) independently assessed randomisation, blinding, and adequacy of analyses (Jüni 2001). Disagreements were resolved by consensus. Two components of randomisation were assessed: generation of allocation sequences and concealment of allocation. Generation of sequences was considered adequate if it resulted in an unpredictable allocation schedule; mechanisms considered adequate include random-number tables, computer-generated random numbers, minimisation, coin tossing, shuffling cards, and drawing lots. Trials using an unpredictable allocation sequence were considered randomised; trials using potentially predictable allocation mechanisms, such as alternation or the allocation of patients according to date of birth, were considered quasi-randomised. Concealment of allocation was considered adequate if patients and investigators responsible for patient selection were unable to suspect before allocation which treatment was next. Methods considered adequate include central randomisation; pharmacy-controlled randomisation using identical prenumbered containers; and sequentially numbered, sealed, opaque envelopes. Blinding of patients was considered adequate if experimental and control preparations were explicitly described as indistinguishable or if a double-dummy technique was used. Analyses were considered adequate if all randomised patients were included in the analysis according to the intention-to-treat principle. We further assessed the reporting of primary outcomes, sample size calculations, and funding source. Finally, we used GRADE to describe the quality of the overall body of evidence (Guyatt 2008; Higgins 2008), defined as the extent of confidence into the estimates of treatment benefits and harms.

\section{Data synthesis}

Continuous outcomes were summarised using standardised mean differences (SMD), with the differences in mean values at the end of treatment across treatment groups divided by the pooled standard deviation. If differences in mean values at the end of the treatment were unavailable, differences in mean changes were used. If some of the required data were unavailable we used approximations, as previously described (Reichenbach 2007). An SMD of -0.20 standard deviation units can be considered a small difference between the experimental and control groups, an SMD of 0.50 a moderate difference, and -0.80 a large difference (Cohen 1988; Jüni 2006). SMDs can also be interpreted in terms of the percent of overlap of the experimental group's scores with scores of the control group. An SMD of - 0.20 indicates an overlap in the distribution of pain or function scores in about $85 \%$ of cases, an SMD of -0.50 in approximately $67 \%$, and an SMD of -0.80 in about 53\% of cases (Cohen 1988; Jüni 2006). On the basis of a median pooled SD of $2.5 \mathrm{~cm}$, found in large-scale osteoarthritis trials that assessed pain using a $10 \mathrm{~cm}$ visual analogue scale (VAS) (Nüesch 2009), SMDs of $-0.20,-0.50$, and -0.80 correspond to approximate differences in pain scores between experimental and control groups of $0.5,1.25$ and $2.0 \mathrm{~cm}$ on a $10 \mathrm{~cm}$ VAS. SMDs for function were back transformed to a standardised WOMAC disability score (Bellamy 1995) ranging from 0 to 10 on the basis of a median pooled SD of 2.1 units observed in large-scale osteoarthritis trials (Nüesch 2009). Binary outcomes were expressed as relative risks.

We used standard inverse-variance random-effects meta-analysis to combine the trials (DerSimonian 1986). We quantified heterogeneity between trials using the $\mathrm{I}^{2}$ statistic (Higgins 2003), which describes the percentage of variation across trials that is attributable to heterogeneity rather than to chance. $\mathrm{I}^{2}$ values of $25 \%, 50 \%$, and $75 \%$ may be interpreted as low, moderate, and high betweentrial heterogeneity, although its interpretation depends on the size and number of trials included (Rücker 2008). The association between trial size and treatment effects was investigated in funnel plots, plotting effect sizes on the vertical axis against their standard errors on the horizontal axis. We assessed asymmetry by the asymmetry coefficient, the difference in effect size per unit increase in standard error (Sterne 2001) which is mainly a surrogate for sample size, and used uni-variable, meta-regression analysis to predict treatment effects in trials as large as the largest trials included in the meta-analysis using the standard error as the explanatory variable (Shang 2005). We then performed analyses of the primary outcomes, pain and function, stratified by the following trial characteristics: type of opioid, analgesic potency (strong versus weak), route of administration (oral versus transdermal), type of control (placebo versus no intervention), concealment of allocation (adequate versus inadequate or unclear), blinding of patients (adequate versus inadequate or unclear), analysis in accordance with the intention-to-treat principle (yes versus no or unclear), trial size, funding, and duration of treatment. Fentanyl, morphine, oxycodone, and oxymorphone were classified as strong opioids, codeine and dextropropoxyphene as weak opioids. A cut off of 200 allocated patients was used to distinguish between small-scale and large-scale trials. A sample size of $2 \times 100$ patients will yield more than $80 \%$ power to detect a small to moderate SMD of -0.40 at a two-sided $\mathrm{P}$ of 0.05 , which corresponds to a difference of $1 \mathrm{~cm}$ on 
a $10 \mathrm{~cm}$ VAS between the experimental and control intervention. A cut off of one month was used to distinguish between shortterm and long-term trials. Uni-variable, random-effects meta-regression models were used to determine whether treatment effects were affected by these factors (Thompson 1999). In addition, the following two continuous variables at trial level were included in uni-variable meta-regression: daily morphine equivalence dosage and treatment duration. Morphine equivalence doses were calculated as previously described (Loeser 2001; Schug 2006): $10 \mathrm{mg}$ oral morphine was considered equivalent to $65 \mathrm{mg}$ oral codeine, $2 \mu \mathrm{g} /$ hour transdermal fentanyl, $7.5 \mathrm{mg}$ oral oxycodone, and 10 mg oral oxymorphone.

We converted SMDs of pain intensity and function to odds ratios (Chinn 2000) to derive numbers needed to treat (NNT) to cause one additional treatment response on pain or function as compared with placebo, and numbers needed to harm $(\mathrm{NNH})$ to cause one additional adverse outcome. We defined treatment response as a $50 \%$ improvement in scores (Clegg 2006). With a median standardised pain intensity at baseline of 2.4 standard deviation units, observed in large osteoarthritis trials (Nüesch 2009), this corresponds to an average decrease in scores of 1.2 standard deviation units. Based on the median standardised decrease in pain scores of 0.72 standard deviation units (Nüesch 2009), we calculated that a median of $31 \%$ of patients in the placebo group would achieve an improvement of pain scores of $50 \%$ or more. This percentage was used as the control group response rate to calculate NNTs for treatment response on pain. Based on the median standardised WOMAC function score at baseline of 2.7 standard deviation units and the median standardised decrease in function scores of 0.58 standard deviation units (Nüesch 2009), 26\% of patients in the placebo group would achieve a reduction in function of $50 \%$ or more. Again, this percentage was used as the control group response rate to calculate NNTs for treatment response on function. The median risks of 150 patients with adverse events per 1000 patient-years, 4 patients with serious adverse events per 1000 patient-years, and 17 dropouts due to adverse events per 1000 patient-years as observed in placebo groups in large osteoarthritis trials (Nüesch 2009) were used to calculate NNHs for safety outcomes. All P-values are two-sided. Analyses were performed using RevMan version 5 (Nordic Cochrane Centre, Cochrane Collaboration, Copenhagen) and STATA version 10.1 (StataCorp, College Station, Texas).

\section{RES U L T S}

\section{Description of studies}

See: Characteristics of included studies; Characteristics of excluded studies; Characteristics of studies awaiting classification.

We identified 2563 potentially relevant references through our electronic searches (Figure 1); 2484 references were excluded after screening titles and abstracts and 79 potentially relevant references were retrieved for full-text assessment. Ten randomised controlled trials were included in the review. Checking reference lists and handsearching of conference proceedings did not yield any additional trials.

Three trials evaluated weak opioids. All three compared codeine with placebo (Kjaersgaard-Andersen 1990; Quiding 1992; Peloso 2000), one of these with paracetamol $3000 \mathrm{mg}$ daily as analgesic co-intervention administered in both the experimental and control groups (Kjaersgaard-Andersen 1990) and another with ibuprofen $1200 \mathrm{mg}$ daily administered in both groups (Quiding 1992). Strong opioids were compared to placebo in seven trials. Morphine was used in one trial (Caldwell 2002), oxymorphone in two (Matsumoto 2005; Kivitz 2006), oxycodone in four (Chindalore 2005; Markenson 2005; Matsumoto 2005; Zautra 2005), and transdermal fentanyl in one trial (Langford 2006). Fentanyl was the only opioid applied by a transdermal route, all others were given orally. Opioids were administered at a median daily dose of $51 \mathrm{mg}$ morphine equivalents (range 13 to $160 \mathrm{mg}$ ).

The median treatment duration was four weeks (range 3 days to 3 months). Trials randomised a median number of $161 \mathrm{pa}-$ tients (range 27 to 491 patients). Nine trials (90\%) were multicentre parallel-group trials, one was a multicentre crossover trial ( Quiding 1992). Two trials exclusively included patients with hip osteoarthritis (Kjaersgaard-Andersen 1990; Quiding 1992), one trial included only patients with knee osteoarthritis (Zautra 2005), and six trials included a mixed population of both knee and hip osteoarthritis (Peloso 2000; Chindalore 2005; Markenson 2005; Matsumoto 2005; Kivitz 2006; Langford 2006). In six studies only patients with insufficient analgesic response to paracetamol, NSAIDs, or previous opioids treatment were included (Caldwell 2002; Chindalore 2005; Kivitz 2006; Langford 2006; Markenson 2005; Matsumoto 2005). The three trials assessing codeine included patients with a need for analgesic treatment but without any requirement of previous insufficient treatment response (Kjaersgaard-Andersen 1990; Quiding 1992; Peloso 2000); one trial did not provide information about eligibility criteria concerning the previous analgesic therapy (Zautra 2005).

The Characteristics of excluded studies table displays the reasons why trials were not considered in this systematic review. Typical reasons were more than $25 \%$ of patients with rheumatoid arthritis in the sample, the use of active control interventions, or the use of crossover designs without providing sufficient information on the first phase.

\section{Risk of bias in included studies}

Figure 2 summarises the methodological characteristics and sources of funding of included trials. Three trials (30\%) reported both adequate sequence generation and adequate allocation concealment (Markenson 2005; Kivitz 2006; Langford 2006); one trial reported only adequate sequence generation (Matsumoto 
2005); and one trial reported adequate concealment but remained unclear about the generation of allocation sequence (Zautra 2005). In the remaining five trials, low quality of reporting hampered any judgment regarding sequence generation and concealment of allocation. All 10 trials were described as double blind. Seven trials reported the use of indistinguishable interventions to blind patients whereas the other three trials used double-dummy techniques (Quiding 1992; Caldwell 2002; Kivitz 2006). However, only six trials explicitly reported adequate blinding of physicians (Chindalore 2005; Markenson 2005; Matsumoto 2005; Zautra 2005; Kivitz 2006; Langford 2006). Seven trials described their analysis to be according to the intention-to-treat principle (Peloso 2000; Chindalore 2005; Markenson 2005; Matsumoto 2005; Zautra 2005; Kivitz 2006; Langford 2006), but none were considered to have an intention-to-treat analysis of pain and function outcomes at end of treatment according to our criteria. Exclusion of patients from the analysis of pain outcomes ranged from $0.3 \%$ to $52 \%$ in the experimental groups and from $2 \%$ to $33 \%$ in the control groups. For four trials no information was available on the proportion of excluded patients (Quiding 1992; Caldwell 2002; Markenson 2005; Langford 2006). For the analysis of function outcomes, exclusion of patients ranged from $1 \%$ to $48 \%$ in the experimental groups and from $2 \%$ to $37 \%$ in the control groups; in two trials no information was available on the proportion of excluded patients (Caldwell 2002; Markenson 2005). 
Figure 2. Methodological characteristics and source of funding of included trials. (+) indicates low risk of bias, (?) unclear and (-) a high risk of bias on a specific item.

\begin{tabular}{|c|c|c|c|c|c|c|c|c|c|c|c|}
\hline & 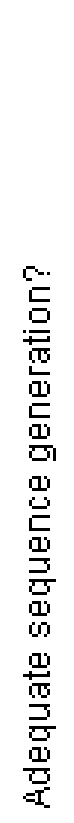 & 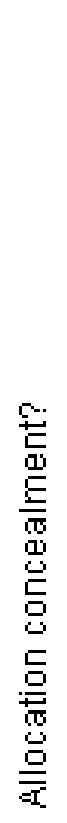 & 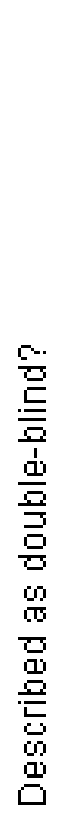 & 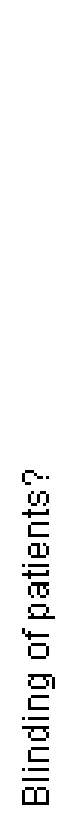 & 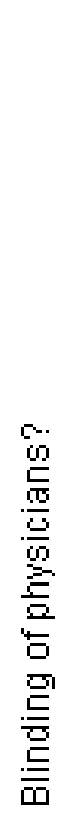 & 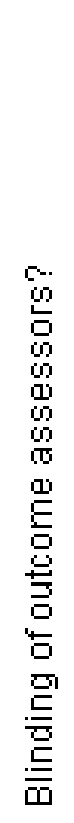 & 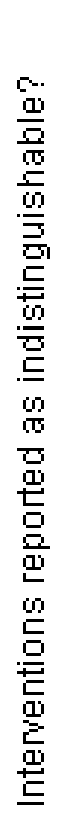 & 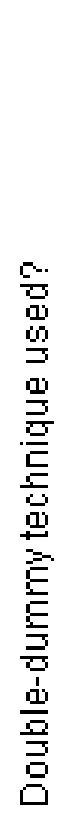 & 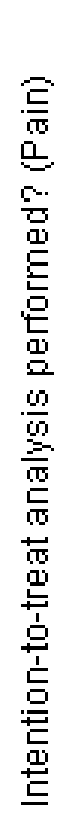 & 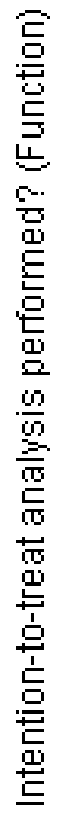 & 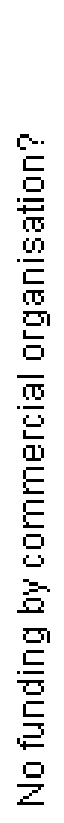 \\
\hline Caldwell 2002 & $?$ & $?$ & + & $\oplus$ & $?$ & + & & + & & & \\
\hline Chindalore 2005 & $?$ & $?$ & $\oplus$ & $\oplus$ & + & + & $\oplus$ & & & & \\
\hline Kivitz 2006 & $\oplus$ & + & $\oplus$ & $\oplus$ & + & $\oplus$ & & & & & \\
\hline Kjaersgaard-Andersen 1990 & $?$ & $?$ & + & $\oplus$ & $?$ & + & $\oplus$ & & 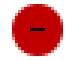 & & $?$ \\
\hline Langford 2006 & + & + & + & + & + & $?$ & + & & & & \\
\hline Markenson 2005 & $\oplus$ & + & $\oplus$ & $\oplus$ & + & + & $\oplus$ & & & & \\
\hline Matsumoto 2005 & + & $?$ & + & $\odot$ & + & + & + & & & & \\
\hline Peloso 2000 & $?$ & $?$ & + & $\odot$ & $?$ & $?$ & + & & & & \\
\hline Quiding 1992 & ? & ? & + & $\odot$ & $?$ & + & & + & $?$ & ? & $?$ \\
\hline Zautra 2005 & $?$ & + & + & + & + & + & + & & & $?$ & \\
\hline
\end{tabular}


Nine trials $(90 \%)$ reported a primary outcome (KjaersgaardAndersen 1990; Peloso 2000; Caldwell 2002; Chindalore 2005; Markenson 2005; Matsumoto 2005; Zautra 2005; Kivitz 2006; Langford 2006) of which five explicitly reported it to be pre-specified in the protocol (Peloso 2000; Caldwell 2002; Markenson 2005; Matsumoto 2005; Langford 2006) and six trials reported a sample size calculation for this primary outcome (KjaersgaardAndersen 1990; Peloso 2000; Markenson 2005; Matsumoto 2005; Kivitz 2006; Langford 2006). Eight trials received financial support from a commercial organisation (Peloso 2000; Caldwell 2002; Chindalore 2005; Markenson 2005; Matsumoto 2005; Zautra 2005; Kivitz 2006; Langford 2006) whereas no trial was explicitly supported by a non-profit organisation. For the effectiveness outcomes pain and function, the quality of the evidence (Guyatt 2008) was classified as high in view of the low risk of bias in the included trials and the low heterogeneity between trials (Summary of findings for the main comparison). For adverse event and serious adverse event outcomes, the quality of the evidence (Guyatt 2008) was classified as moderate to low because of the small number of trials reporting the outcomes and the small number of serious adverse events which resulted in imprecise estimates (Summary of findings for the main comparison).

\section{Effects of interventions}

\section{See: Summary of findings for the main comparison}

\section{Primary outcomes}

\section{Knee or hip pain}

Ten trials including 1541 patients in experimental groups and 727 patients in control groups contributed to the analyses of knee or hip pain. Figure 3 presents results of the analysis, overall and stratified according to type of opioid. In the overall analysis, combined oral and transdermal opioids were more effective in pain reduc- tion than control interventions (SMD - $0.36,95 \%$ CI -0.47 to 0.26), which corresponds to a difference in pain scores of $0.9 \mathrm{~cm}$ on a $10 \mathrm{~cm}$ VAS between opioids and placebo. This corresponds to a difference in improvement of $15 \%$ (95\% CI $11 \%$ to $20 \%)$ between opioids and placebo (Summary of findings for the main comparison). The estimated difference in the percentage of treatment responders of $4 \%$ between opioids and placebo translates into an NNT to cause one additional treatment response on pain of 25 (95\% CI 19 to 34) (Summary of findings for the main comparison ). An $\mathrm{I}^{2}$ of $18 \%$ indicated a low degree of betweentrial heterogeneity ( $\mathrm{P}$ for heterogeneity $=0.27$ ). A visual inspection of the funnel plot suggested slight asymmetry (asymmetry coefficient $-1.66,95 \%$ CI -3.74 to 0.43 ) and the test for asymmetry indicated limited evidence for asymmetry $(\mathrm{P}=0.10)$ (Figure 4). Benefits were moderate for codeine (SMD - $0.51,95 \%$ CI -1.01 to $-0.01 ; 3$ trials), small to moderate for oxycodone (SMD -0.42 , $95 \%$ CI -0.65 to $-0.20 ; 4$ trials) and oxymorphone (SMD -0.39, $95 \%$ CI -0.58 to $-0.21 ; 2$ trials), and small for morphine (SMD $-0.32,95 \% \mathrm{CI}-0.59$ to $-0.06 ; 1$ trial) and transdermal fentanyl (SMD - $0.22,95 \%$ CI -0.42 to -0.03 ; 1 trial). The confidence intervals were wide and a test for interaction between benefit and type of opioid was non-significant $(\mathrm{P}=0.89)$. Table 1 presents the results of stratified analyses. We found little evidence for an association of SMDs with analgesic potency, route of administration, type of control intervention, treatment duration, use of analgesic co-interventions, concealment of allocation, or sample size. All the trials had blinded patients adequately, none had performed analyses according to the intention-to-treat principle. Therefore, we could not evaluate the impact of these characteristics. Fourteen comparisons from 10 trials contributed to the analysis of a linear association between equivalence dose and treatment benefit ( Figure 5). We found little evidence for a linear association between daily equivalence doses and pain reduction $(\mathrm{P}=0.47)$. 
Figure 3. Forest plot of 10 trials comparing the effects of any type of opioids and control (placebo or no intervention) on knee or hip pain. Values on $x$-axis denote standardised mean differences. The plot is stratified according to type of opioids. Matsumoto 2005 contributed with two comparisons and the standard error was inflated and the number of patients in the placebo group was halfed to avoid duplicate counting of patients

when including both comparisons in the overall meta-analysis. Data relating to the 3, 3, 3, and 2 active intervention arms in Caldwell 2002, Chindalore 2005, Kivitz 2006, and Matsumoto 2005, respectively, were pooled.

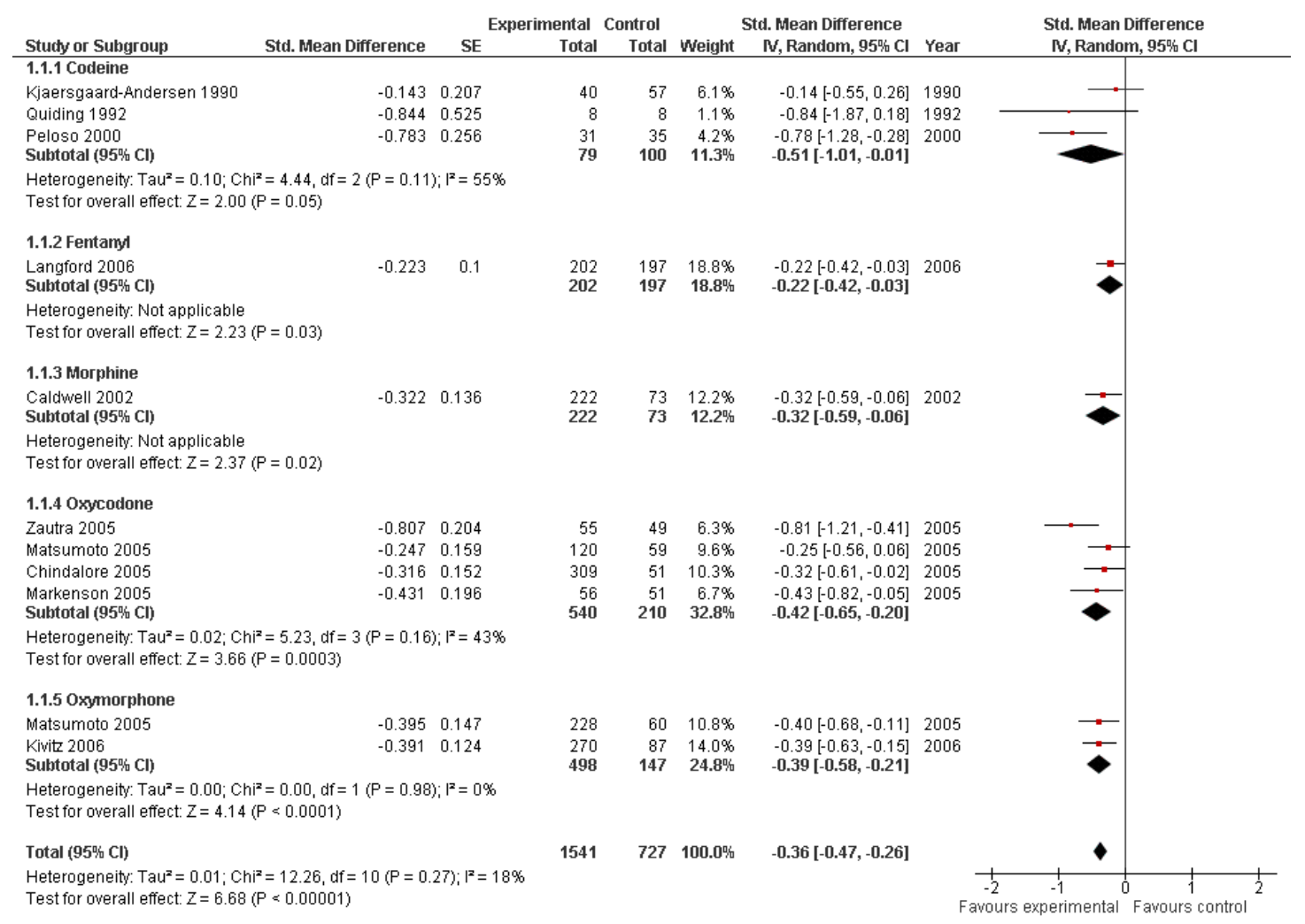


Figure 4. Funnel plot for effects on knee or hip pain.

Numbers on x-axis refer to standardised mean differences (SMDs), on y-axis to standard errors of SMDs.

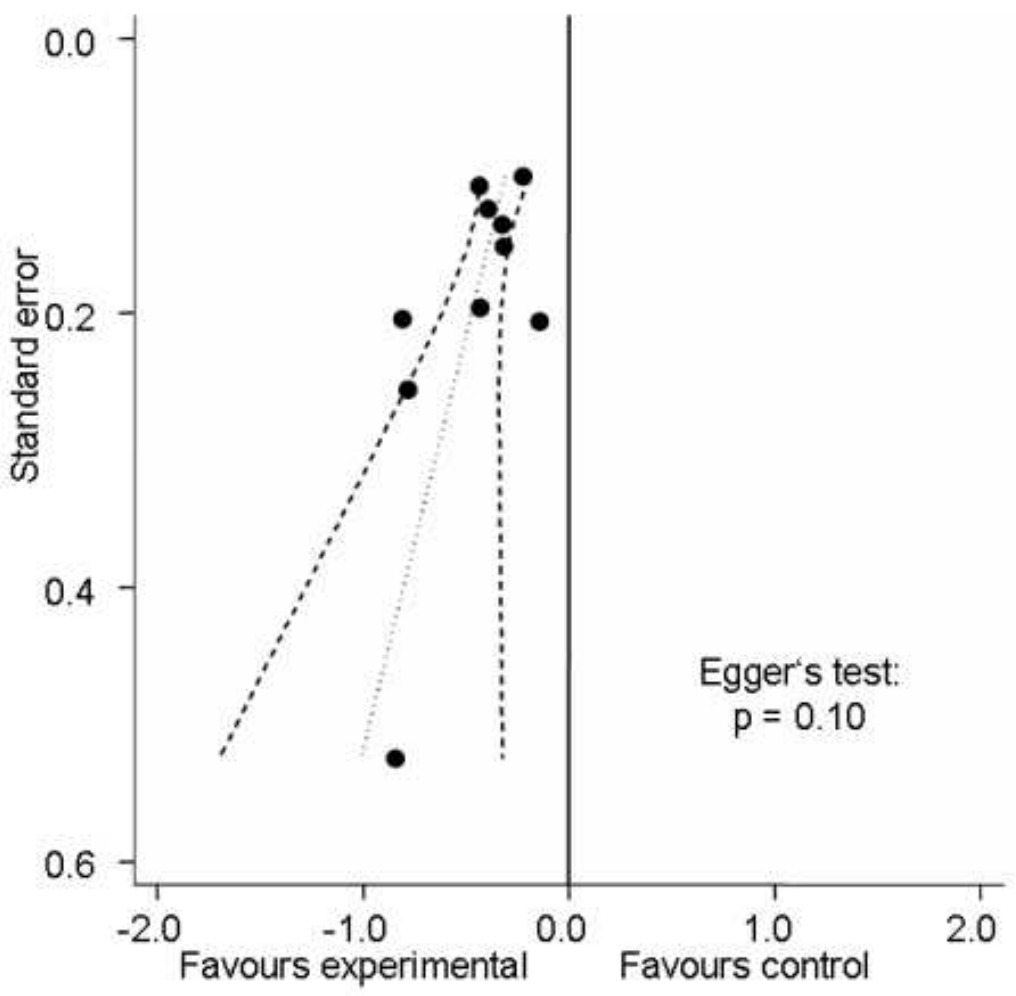


Figure 5. Standardised mean differences of knee or hip pain (y-axis) are plotted against total daily dose of morphine equivalents (x-axis). The size of the circles is proportional to the random-effects weights that were used in the meta-regression. The dotted line indicates predicted treatment effects (regression line) from univariable meta-regression by using daily morphine equivalence doses the explanatory variable, and dashed lines represent the $95 \%$ Cls.

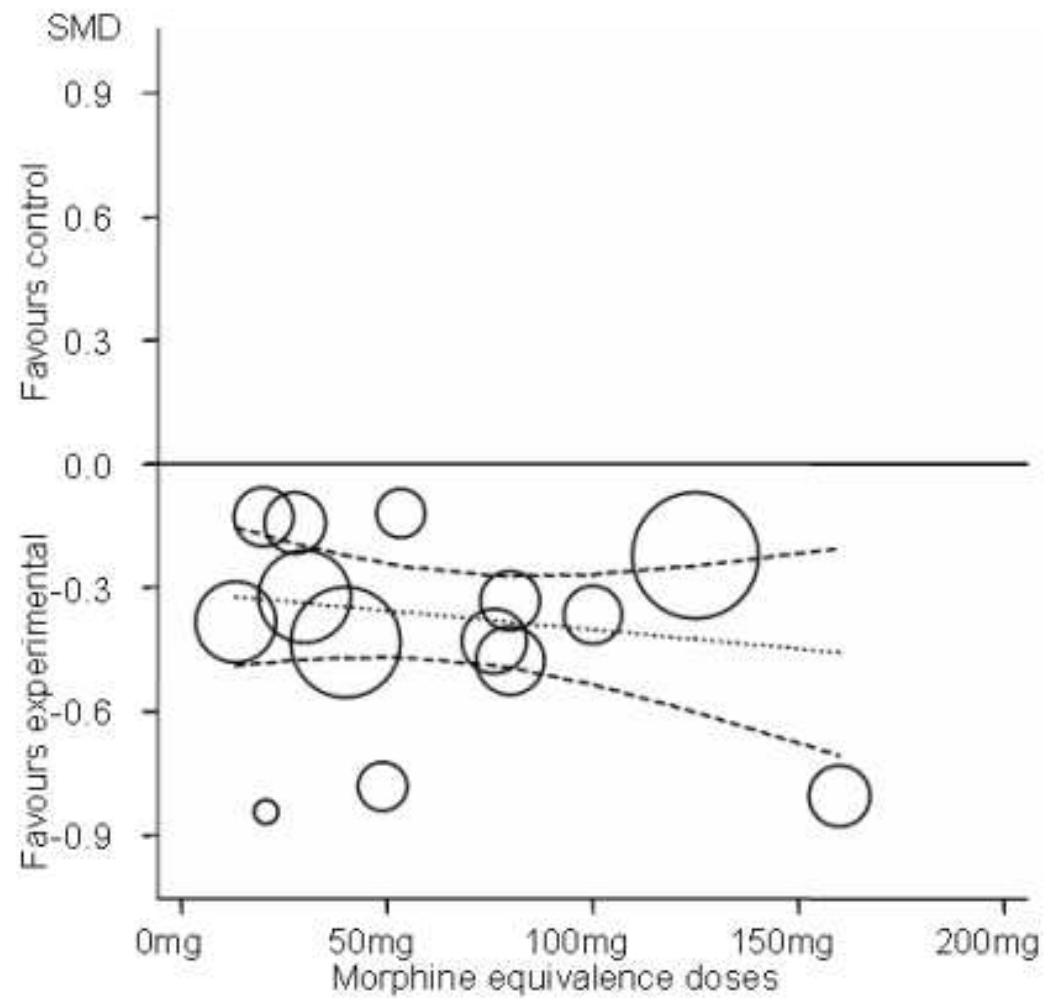


Table 1. Stratified analyses: pain

\begin{tabular}{|c|c|c|c|c|c|c|}
\hline Variable & $\begin{array}{l}\text { Number of } \\
\text { studies }\end{array}$ & $\begin{array}{l}\mathrm{N} \text { of patients } \\
\text { opioids }\end{array}$ & $\begin{array}{l}\mathrm{N} \text { of patients } \\
\text { control }\end{array}$ & $\begin{array}{l}\text { Pain intensity } \\
\text { SMD }(95 \% \text { CI })\end{array}$ & $\begin{array}{l}\text { Hetero- } \\
\text { geneity } \\
\mathrm{I}^{2}(\%)\end{array}$ & P-value* \\
\hline All trials & 10 & 1541 & 727 & $\begin{array}{l}-0.36(-0.47 \text { to }- \\
0.26)\end{array}$ & $18 \%$ & \\
\hline $\begin{array}{l}\text { Analgesic } \\
\text { potency }\end{array}$ & & & & & & 0.74 \\
\hline Weak & 3 & 79 & 100 & $\begin{array}{l}-0.51(-1.01 \text { to }- \\
0.01)\end{array}$ & $55 \%$ & \\
\hline Strong & 7 & 1462 & 627 & $\begin{array}{l}-0.38(-0.49 \text { to }- \\
0.26)\end{array}$ & $19 \%$ & \\
\hline $\begin{array}{l}\text { Route of ad- } \\
\text { ministration }\end{array}$ & & & & & & 0.14 \\
\hline Oral & 9 & 1339 & 530 & $\begin{array}{l}-0.42(-0.54 \text { to }- \\
0.31)\end{array}$ & $12 \%$ & \\
\hline Transdermal & 1 & 202 & 197 & $\begin{array}{l}-0.22(-0.42 \text { to }- \\
0.03)\end{array}$ & N/A & \\
\hline $\begin{array}{l}\text { Allocation con- } \\
\text { cealment }\end{array}$ & & & & & & 0.96 \\
\hline Adequate & 4 & 583 & 384 & $\begin{array}{l}-0.42(-0.64 \text { to }- \\
0.20)\end{array}$ & $56 \%$ & \\
\hline $\begin{array}{l}\text { Inadequate or } \\
\text { unclear }\end{array}$ & 6 & 958 & 343 & $\begin{array}{l}-0.38(-0.52 \text { to }- \\
0.25)\end{array}$ & $3 \%$ & \\
\hline $\begin{array}{l}\text { Type of control } \\
\text { intervention }\end{array}$ & & & & & & 0.53 \\
\hline Placebo & 8 & 1493 & 662 & $\begin{array}{l}-0.40(-0.52 \text { to }- \\
0.28)\end{array}$ & $30 \%$ & \\
\hline $\begin{array}{l}\text { No interven- } \\
\text { tion }\end{array}$ & 2 & 48 & 65 & $\begin{array}{ll}-0.33 & (-0.93 \text { to } \\
0.28) & \end{array}$ & $35 \%$ & \\
\hline
\end{tabular}


Table 1. Stratified analyses: pain (Continued)

\begin{tabular}{|c|c|c|c|c|c|c|}
\hline $\begin{array}{l}\text { Number } \\
\text { of patients ran- } \\
\text { domised }\end{array}$ & & & & & & 0.15 \\
\hline$>200$ & 5 & 1351 & 527 & $\begin{array}{l}-0.33(-0.44 \text { to }- \\
0.23)\end{array}$ & $0 \%$ & \\
\hline$\leq 200$ & 5 & 190 & 200 & $\begin{array}{l}-0.55(-0.83 \text { to }- \\
0.27)\end{array}$ & $42 \%$ & \\
\hline $\begin{array}{l}\text { Duration of } \\
\text { treatment }\end{array}$ & & & & & & 0.23 \\
\hline$>1$ month & 2 & 258 & 248 & $\begin{array}{l}-0.27(-0.44 \text { to }- \\
0.09)\end{array}$ & $0 \%$ & \\
\hline$\leq 1$ month & 8 & 1283 & 479 & $\begin{array}{l}-0.43(-0.56 \text { to }- \\
0.29)\end{array}$ & $23 \%$ & \\
\hline $\begin{array}{l}\text { Use of analgesic } \\
\text { co- } \\
\text { interventions }\end{array}$ & & & & & & 0.66 \\
\hline $\begin{array}{l}\text { Similar be- } \\
\text { tween groups }\end{array}$ & 3 & 289 & 283 & $\begin{array}{l}-0.41(-0.71 \text { to }- \\
0.11)\end{array}$ & $56 \%$ & \\
\hline Unclear & 7 & 1252 & 444 & $\begin{array}{l}-0.40(-0.53 \text { to }- \\
0.28)\end{array}$ & $14 \%$ & \\
\hline
\end{tabular}

*P-value for interaction

\section{Function}

Seven studies including 1172 patients in experimental groups and 622 patients in control groups contributed to the analysis of function. Improvement of function was larger in opioid treated patients compared to control groups (SMD - $0.33,95 \% \mathrm{CI}-0.45$ to -0.12) (Figure 6), which corresponds to a difference in function scores of 0.7 units between opioids and placebo on a standardised WOMAC disability scale ranging from 0 to 10 . This corresponds to a difference in improvement of 13\% (95\% CI 9\% to $18 \%$ ) between opioids and placebo (Summary of findings for the main comparison). The estimated difference in the percentage of treatment responders between patients allocated to opioids and patients allocated to placebo of $3 \%$ translated into an NNT to cause one additional treatment response on function of 30 (95\% CI 22 to 46) (Summary of findings for the main comparison ). An $\mathrm{I}^{2}$ of $24 \%$ indicated a low degree of between-trial heterogeneity
( $\mathrm{P}$ for heterogeneity $=0.24)$. We found a moderate benefit for codeine (SMD - $0.42,95 \%$ CI -0.74 to $-0.10 ; 2$ trials) and oxycodone (SMD $-0.44,95 \%$ CI -1.12 to $0.24 ; 2$ trials) and small effects for oxymorphone (SMD $-0.32,95 \%$ CI -0.50 to -0.13 ; 2 trials), morphine (SMD $-0.29,95 \% \mathrm{CI}-0.56$ to $-0.03 ; 1$ trial) and transdermal fentanyl (SMD $-0.28,95 \%$ CI -0.48 to $-0.09 ; 1$ trial). As was the case for pain, confidence intervals of estimates were wide and a test for interaction between benefit and type of opioid was non-significant $(P=0.98)$. Heterogeneity between the two trials that studied effects of oxycodone was high with an $\mathrm{I}^{2}$ estimate of $86 \%$ ( $\mathrm{P}$ for heterogeneity $<0.001$ ), but low for the other types of opioid. The funnel plot (Figure 7) appeared somewhat asymmetrical (asymmetry coefficient $-2.49,95 \%$ CI -5.75 to 0.77 , $\mathrm{P}$ for asymmetry $=0.07$ ). Table 2 presents the results of the stratified analyses. Again, we found little evidence for an association of SMDs with analgesic potency, route of administration, 
type of control intervention, treatment duration, use of analgesic co-interventions, and allocation concealment. Adequately powered trials with more than 200 randomised patients tended to show smaller improvements of function (P for interaction $=0.09$ ). Ten comparisons from seven trials contributed to the analysis of a linear association between equivalence dose and treatment benefit for function (Figure 8). We found no evidence for an association between daily equivalence doses and improvement of function ( $\mathrm{P}$ $=0.82$ ).

Figure 6. Forest plot of $\mathbf{7}$ trials comparing the effects of any type of opioids and control (placebo or no intervention) on function. Values on x-axis denote standardised mean differences. The plot is stratified according to type of opioids. Matsumoto 2005 contributed with two comparisons and the standard error was inflated and the number of patients in the placebo group was halved to avoid duplicate counting of patients

when including both comparisons in the overall meta-analysis. Data relating to the 3, 3, and 2 active intervention arms in Caldwell 2002, Kivitz 2006, and Matsumoto 2005, respectively, were pooled.

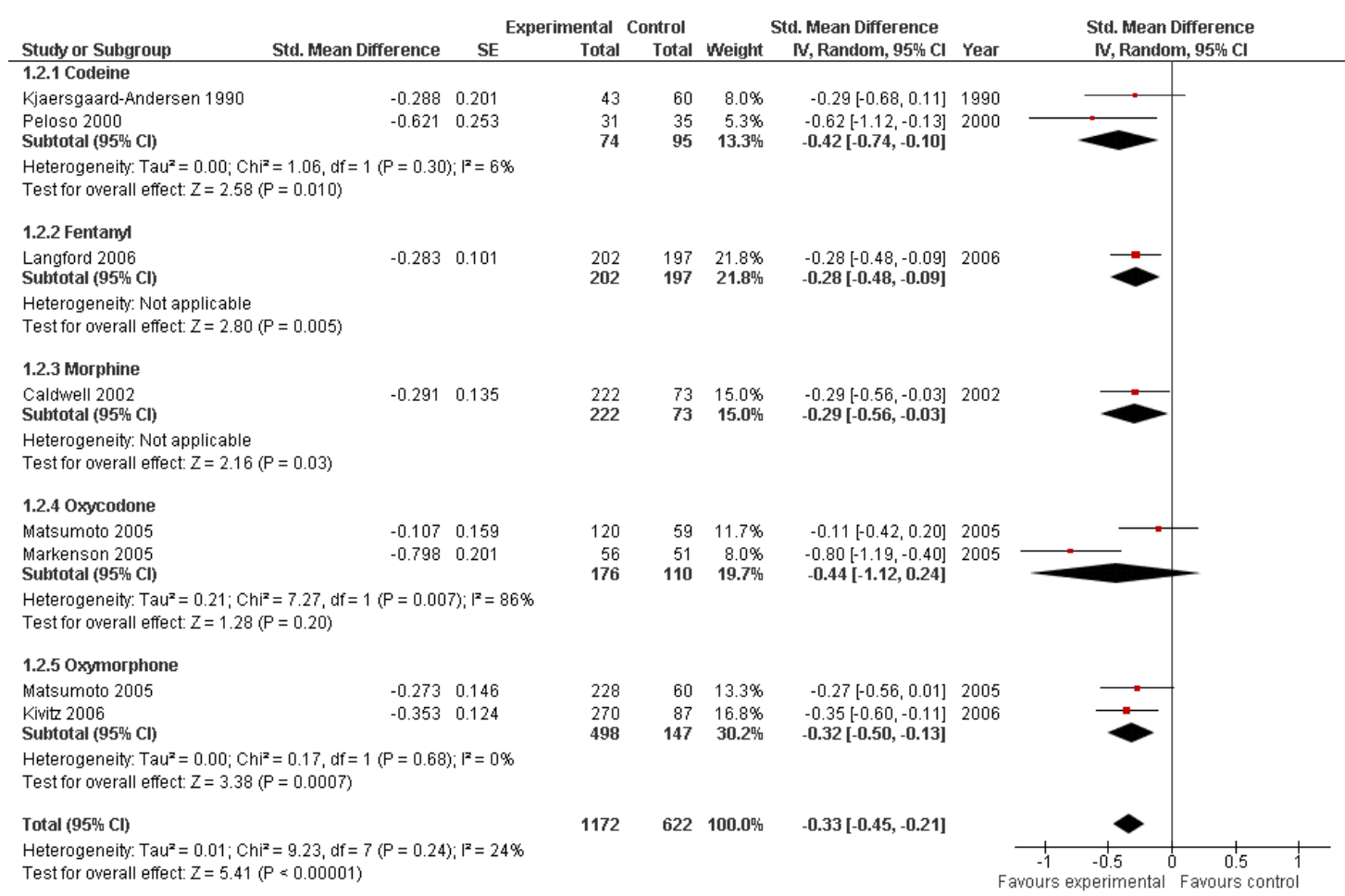


Figure 7. Funnel plot for effects on functioning of the knee or hip. Numbers on $x$-axis refer to standardised mean differences (SMDs), on y-axis to standard errors of SMDs

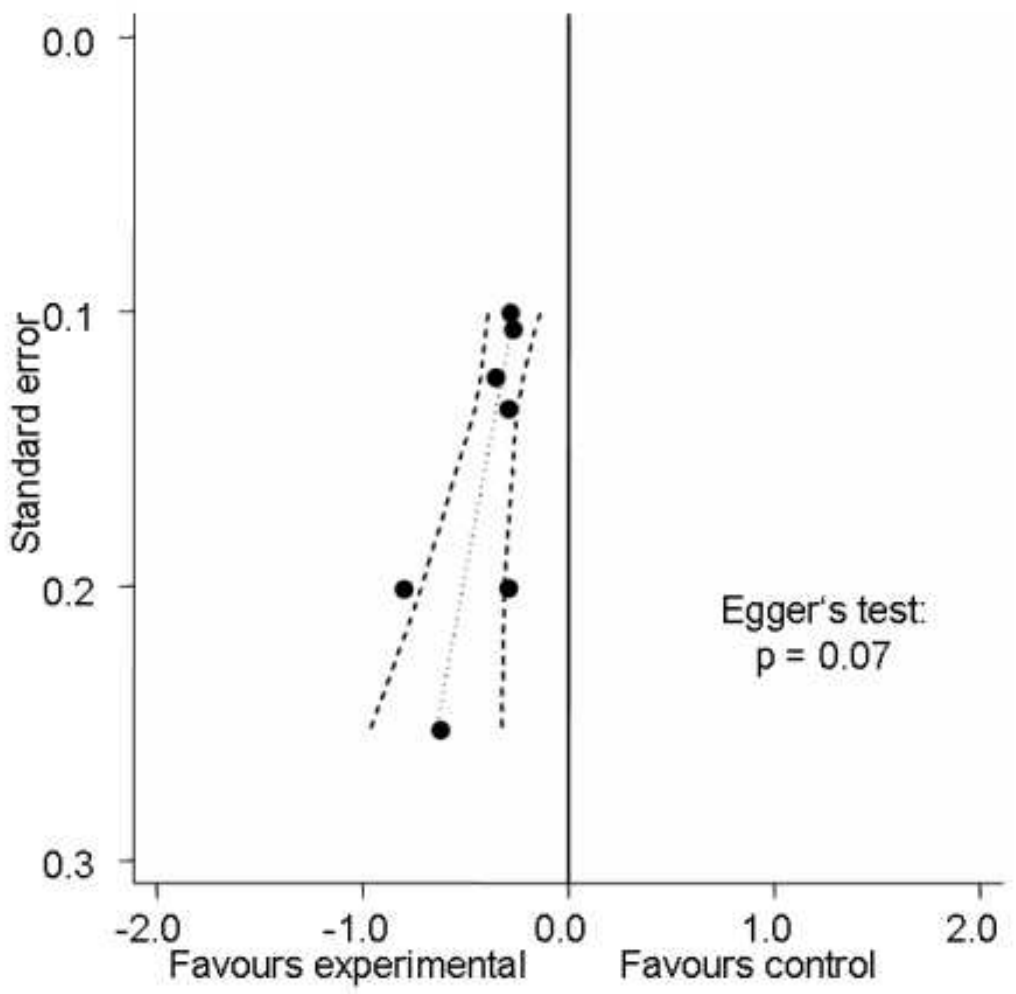


Figure 8. Standardised mean differences of function (y-axis) are plotted against total daily dose of morphine equivalents (x-axis). The size of the circles is proportional to the random-effects weights that were used in the meta-regression. The dotted line indicates predicted treatment effects (regression line) from uni-variable meta-regression by using daily morphine equivalence doses the explanatory variable, and dashed lines represent the $95 \%$ Cls.

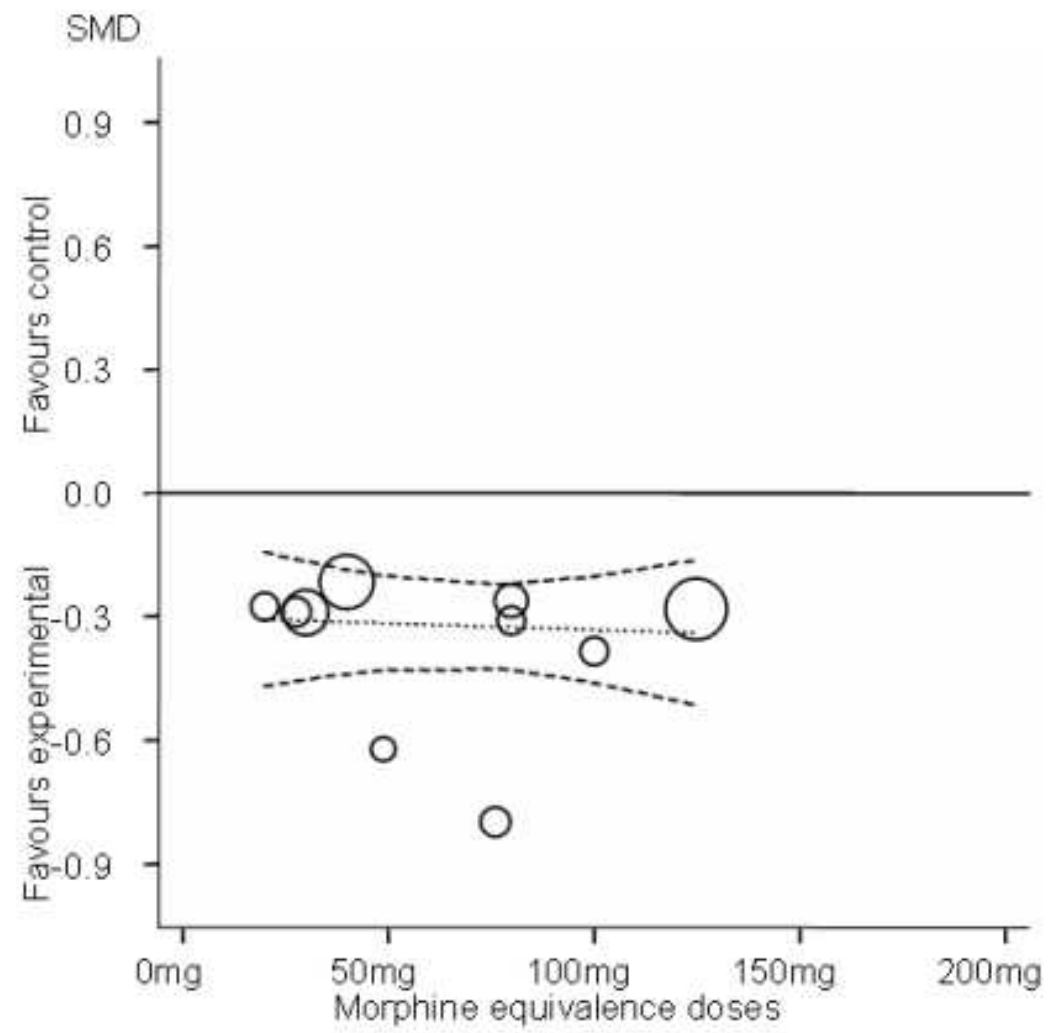

Table 2. Stratified analyses: function

\begin{tabular}{|c|c|c|c|c|c|c|}
\hline Variable & $\begin{array}{l}\text { Number of } \\
\text { studies }\end{array}$ & $\begin{array}{l}\mathrm{N} \text { of patients } \\
\text { opioids }\end{array}$ & $\begin{array}{l}\mathrm{N} \text { of patients } \\
\text { control }\end{array}$ & $\begin{array}{l}\text { Function } \\
\text { SMD }(95 \% \mathrm{CI})\end{array}$ & $\begin{array}{l}\text { Hetero- } \\
\text { geneity } \\
\mathrm{I}^{2}(\%)\end{array}$ & P-value* \\
\hline All trials & 7 & 1172 & 622 & $\begin{array}{l}-0.33(-0.45 \text { to }- \\
0.21)\end{array}$ & $24 \%$ & \\
\hline $\begin{array}{l}\text { Analgesic } \\
\text { potency }\end{array}$ & & & & & & 0.68 \\
\hline
\end{tabular}


Table 2. Stratified analyses: function (Continued)

\begin{tabular}{|c|c|c|c|c|c|c|}
\hline Weak & 2 & 74 & 95 & $\begin{array}{l}-0.42(-0.74 \text { to }- \\
0.10)\end{array}$ & $6 \%$ & \\
\hline Strong & 5 & 1098 & 527 & $\begin{array}{l}-0.35(-0.48 \text { to }- \\
0.21)\end{array}$ & $34 \%$ & \\
\hline $\begin{array}{l}\text { Route of ad- } \\
\text { ministration }\end{array}$ & & & & & & 0.58 \\
\hline Oral & 6 & 970 & 425 & $\begin{array}{l}-0.38(-0.53 \text { to }- \\
0.23)\end{array}$ & $28 \%$ & \\
\hline Transdermal & 1 & 202 & 197 & $\begin{array}{l}-0.28(-0.48 \text { to }- \\
0.09)\end{array}$ & N/A & \\
\hline $\begin{array}{l}\text { Allocation con- } \\
\text { cealment }\end{array}$ & & & & & & 0.60 \\
\hline Adequate & 3 & 528 & 335 & $\begin{array}{l}-0.43(-0.68 \text { to }- \\
0.18)\end{array}$ & $62 \%$ & \\
\hline $\begin{array}{l}\text { Inadequate or } \\
\text { unclear }\end{array}$ & 4 & 644 & 287 & $\begin{array}{l}-0.31(-0.45 \text { to }- \\
0.16)\end{array}$ & $0 \%$ & \\
\hline $\begin{array}{l}\text { Type of control } \\
\text { intervention }\end{array}$ & & & & & & 0.83 \\
\hline Placebo & 6 & 1129 & 562 & $\begin{array}{l}-0.36(-0.50 \text { to }- \\
0.23)\end{array}$ & $32 \%$ & \\
\hline $\begin{array}{l}\text { No interven- } \\
\text { tion }\end{array}$ & 1 & 43 & 60 & $\begin{array}{ll}-0.29 & (-0.68 \text { to } \\
0.11) & \end{array}$ & N/A & \\
\hline $\begin{array}{l}\text { Number } \\
\text { of patients ran- } \\
\text { domised }\end{array}$ & & & & & & 0.09 \\
\hline$>200$ & 4 & 1042 & 476 & $\begin{array}{l}-0.29(-0.41 \text { to }- \\
0.18)\end{array}$ & $0 \%$ & \\
\hline$\leq 200$ & 3 & 130 & 146 & $\begin{array}{l}-0.56(-0.88 \text { to }- \\
0.25)\end{array}$ & $39 \%$ & \\
\hline $\begin{array}{l}\text { Duration of } \\
\text { treatment }\end{array}$ & & & & & & 0.55 \\
\hline
\end{tabular}


Table 2. Stratified analyses: function (Continued)

\begin{tabular}{|c|c|c|c|c|c|c|}
\hline$>1$ month & 2 & 258 & 248 & $\begin{array}{l}-0.51(-1.01 \text { to }- \\
0.01)\end{array}$ & $81 \%$ & \\
\hline$\leq 1$ month & 5 & 914 & 374 & $\begin{array}{l}-0.32(-0.44 \text { to }- \\
0.19)\end{array}$ & $0 \%$ & \\
\hline $\begin{array}{l}\text { Use of analgesic } \\
\text { co- } \\
\text { interventions }\end{array}$ & & & & & & 0.29 \\
\hline $\begin{array}{l}\text { Similar be- } \\
\text { tween groups }\end{array}$ & 3 & 289 & 283 & $\begin{array}{l}-0.53(-0.88 \text { to }- \\
0.18)\end{array}$ & $67 \%$ & \\
\hline Unclear & 4 & 883 & 339 & $\begin{array}{l}-0.30(-0.43 \text { to }- \\
0.17)\end{array}$ & $0 \%$ & \\
\hline
\end{tabular}

${ }^{*} \mathrm{P}$-value for interaction

\section{Secondary outcomes}

Four trials reported the occurrence of any adverse event in 579 out of 670 patients in experimental groups and 222 of 410 patients in control groups (Figure 9). Patients were 55\% more likely to experience adverse events in experimental groups compared to placebo (RR 1.55, 95\% CI 1.41 to 1.70). The NNH to cause one additional patient to experience an adverse event, as compared to placebo, was 12 (95\% CI 10 to 16) (Summary of findings for the main comparison ). Results were consistent between different studies $\left(\mathrm{I}^{2}=0 \%\right.$, P for heterogeneity $\left.=0.75\right)$ and different types of opioids ( $\mathrm{P}$ for interaction $=0.95$ ). Due to the low number of trials, we did not perform an analysis of the association between equivalence dose and log relative risk for this outcome. 
Figure 9. Forest plot of $\mathbf{4}$ trials comparing patients experiencing any adverse event between any opioid and control (placebo or no intervention). Values on $\mathbf{x}$-axis denote risks ratios. The plot is stratified according to type of opioid. Matsumoto 2005 contributed with two comparisons and the number of patients in the placebo group was halved to avoid duplicate counting of patients when including both comparisons in the overall metaanalysis.

\begin{tabular}{|c|c|c|c|c|c|c|c|c|c|}
\hline Stucty or Subgroup & \multicolumn{2}{|c|}{ Experimental } & \multicolumn{2}{|c|}{ Control } & \multicolumn{3}{|c|}{ Risk Ratio } & \multicolumn{2}{|c|}{$\begin{array}{c}\text { Risk Ratio } \\
\text { N, Random, } 95 \% \mathrm{Cl}\end{array}$} \\
\hline \multicolumn{10}{|l|}{ 1.3.1 Codeine } \\
\hline $\begin{array}{l}\text { Peloso } 2000 \\
\text { Subtotal (95\% Cl) }\end{array}$ & 25 & $\begin{array}{l}31 \\
31\end{array}$ & 22 & $\begin{array}{l}35 \\
35\end{array}$ & $\begin{array}{l}9.7 \% \\
9.7 \%\end{array}$ & $\begin{array}{r}1.28[0.94,1.75] \\
\mathbf{1 . 2 8}[\mathbf{0 . 9 4}, \mathbf{1 . 7 5}]\end{array}$ & 2000 & & \\
\hline \multicolumn{10}{|c|}{$\begin{array}{l}\text { Heterogeneity: Not applicable } \\
\text { Test for overall effect: } Z=1.59(P=0.11)\end{array}$} \\
\hline \multicolumn{10}{|l|}{ 1.3.2 Fentamyl } \\
\hline $\begin{array}{l}\text { Langford } 2006 \\
\text { Subtotal (95\% Cl) }\end{array}$ & 169 & $\begin{array}{l}216 \\
216\end{array}$ & 101 & $\begin{array}{l}200 \\
200\end{array}$ & $\begin{array}{l}38.8 \% \\
38.8 \%\end{array}$ & $\begin{array}{r}1.55[1.33,1.81] \\
\mathbf{1 . 5 5}[\mathbf{1 . 3 3}, \mathbf{1 . 8 1}]\end{array}$ & 2006 & & \\
\hline \multicolumn{10}{|c|}{$\begin{array}{l}\text { Heterogeneity: Not applicable } \\
\text { Test for overall effect: } Z=5.57 \text { ( } P<0.00001)\end{array}$} \\
\hline \multicolumn{10}{|l|}{ 1.3.3 Oxycodone } \\
\hline Matsumoto 2005 & 110 & 125 & 35 & 62 & $17.7 \%$ & $1.56[1.24,1.96]$ & 2005 & & \\
\hline $\begin{array}{l}\text { Markenson } 2005 \\
\text { Subtotal }(95 \% \mathrm{Cl})\end{array}$ & 52 & $\begin{array}{r}56 \\
181\end{array}$ & 28 & $\begin{array}{r}51 \\
113\end{array}$ & $\begin{array}{l}13.7 \% \\
31.5 \%\end{array}$ & $\begin{array}{l}1.69[1.31,2.19] \\
\mathbf{1 . 6 2}[\mathbf{1 . 3 6}, \mathbf{1 . 9 2}]\end{array}$ & 2005 & & \\
\hline \multicolumn{10}{|c|}{$\begin{array}{l}\text { Heterogeneity: } \operatorname{Tau}^{2}=0.00 ; \mathrm{Chi}^{2}=0.21, \mathrm{df}=1(\mathrm{P}=0.64) ; \mathrm{I}^{2}=0 \% \\
\text { Test for overall effect: } Z=5.49(\mathrm{P}<0.00001)\end{array}$} \\
\hline \multicolumn{10}{|l|}{ 1.3.4 Oxymorphone } \\
\hline $\begin{array}{l}\text { Matsumoto } 2005 \\
\text { Subtotal }(95 \% \mathrm{Cl})\end{array}$ & 223 & $\begin{array}{l}242 \\
242\end{array}$ & 36 & $\begin{array}{l}62 \\
62\end{array}$ & $\begin{array}{l}20.0 \% \\
20.0 \%\end{array}$ & $\begin{array}{r}1.59[1.28,1.97] \\
\mathbf{1 . 5 9}[\mathbf{1 . 2 8}, \mathbf{1 . 9 7}]\end{array}$ & 2005 & & \\
\hline \multicolumn{10}{|c|}{$\begin{array}{l}\text { Heterogeneity: Not applicable } \\
\text { Test for overall effect: } Z=4.22(P<0.0001)\end{array}$} \\
\hline Total $(95 \% \mathrm{Cl})$ & & 670 & & 410 & $100.0 \%$ & $1.55[1.41,1.70]$ & & & \\
\hline Total events & 579 & & 222 & & & & & & \\
\hline $\begin{array}{l}\text { Heterogeneity: Tau }{ }^{2} \\
\text { Test for overall effect }\end{array}$ & $\begin{array}{l}0.00 ; \mathrm{Chi}^{2} \\
\mathrm{Z}=8.93(\mathrm{l}\end{array}$ & $\begin{array}{l}=1.94 \\
<0.000\end{array}$ & $\begin{array}{l}d f=4(P \\
001)\end{array}$ & $=0.75)$ & $i^{2}=0 \%$ & & & $\begin{array}{cc} & 1 \\
0.5 & 0.7 \\
\text { urs experimen }\end{array}$ & $\begin{array}{r}1.5 \\
\text { Favours C }\end{array}$ \\
\hline
\end{tabular}


Ten trials with 2403 patients contributed to the meta-analysis of patients withdrawn or dropped out because of adverse events ( Figure 10). Patients receiving opioid therapy were four times as likely as patients receiving placebo to be withdrawn or drop out due to adverse events (RR 4.05, 95\% CI 3.06 to 5.38), with little between trial heterogeneity $\left(\mathrm{I}^{2}=8 \%, \mathrm{P}\right.$ for heterogeneity $\left.=0.37\right)$. The NNH to cause one additional dropout or withdrawal due to adverse events compared with placebo was 19 (95\% CI 13 to 29) (Summary of findings for the main comparison ). We found the highest pooled risk ratio for oxycodone versus placebo (RR 7.75, 95\% CI 3.76 to 15.97 ) and the lowest pooled RR for transdermal fentanyl versus placebo (RR 2.63, 95\% CI 1.64 to 4.23 ) but confidence intervals were wide and a test for interaction between type of opioids and relative risk of being withdrawn or dropping out because of adverse events negative gave a $\mathrm{P}$ for interaction of 0.38 . Fourteen comparisons in 10 trials contributed to the analysis of the association between equivalence dose and log relative risk ( Figure 11). We found little evidence for a relationship $(P=0.76)$. 
Figure 10. Forest plot of 10 trials comparing patients withdrawn or dropped out because of adverse events between any opioid and control (placebo or no intervention). Values on $x$-axis denote risks ratios. The plot is stratified according to type of opioid. Matsumoto 2005 contributed with two comparisons and the number of patients in the placebo group was halved to avoid duplicate counting of patients when including both comparisons in the overall meta-analysis. The risk ratio in one trial could not be estimated because no withdrawals or dropouts because of adverse events occurred in either group.

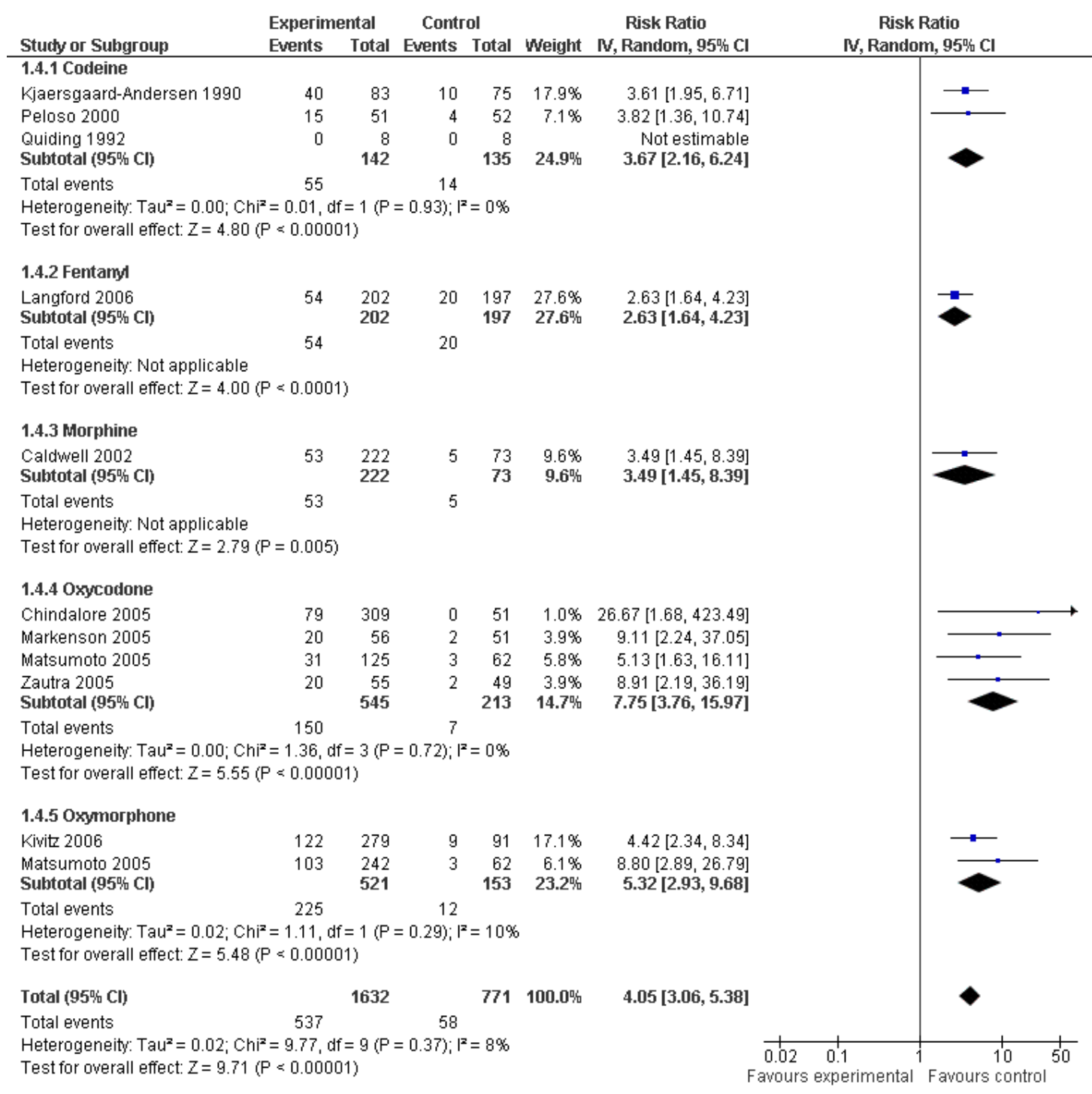


Figure II. Risk ratios of patients withdrawn or dropped out because of adverse events between opioids and control groups (y-axis) are plotted against total daily dose of morphine equivalents (x-axis). The size of the circles is proportional to the random-effects weights that were used in the meta-regression. The dotted line indicates predicted treatment effects (regression line) from uni-variable meta-regression by using daily morphine equivalence doses the explanatory variable, and dashed lines represent the $95 \% \mathrm{Cls}$.

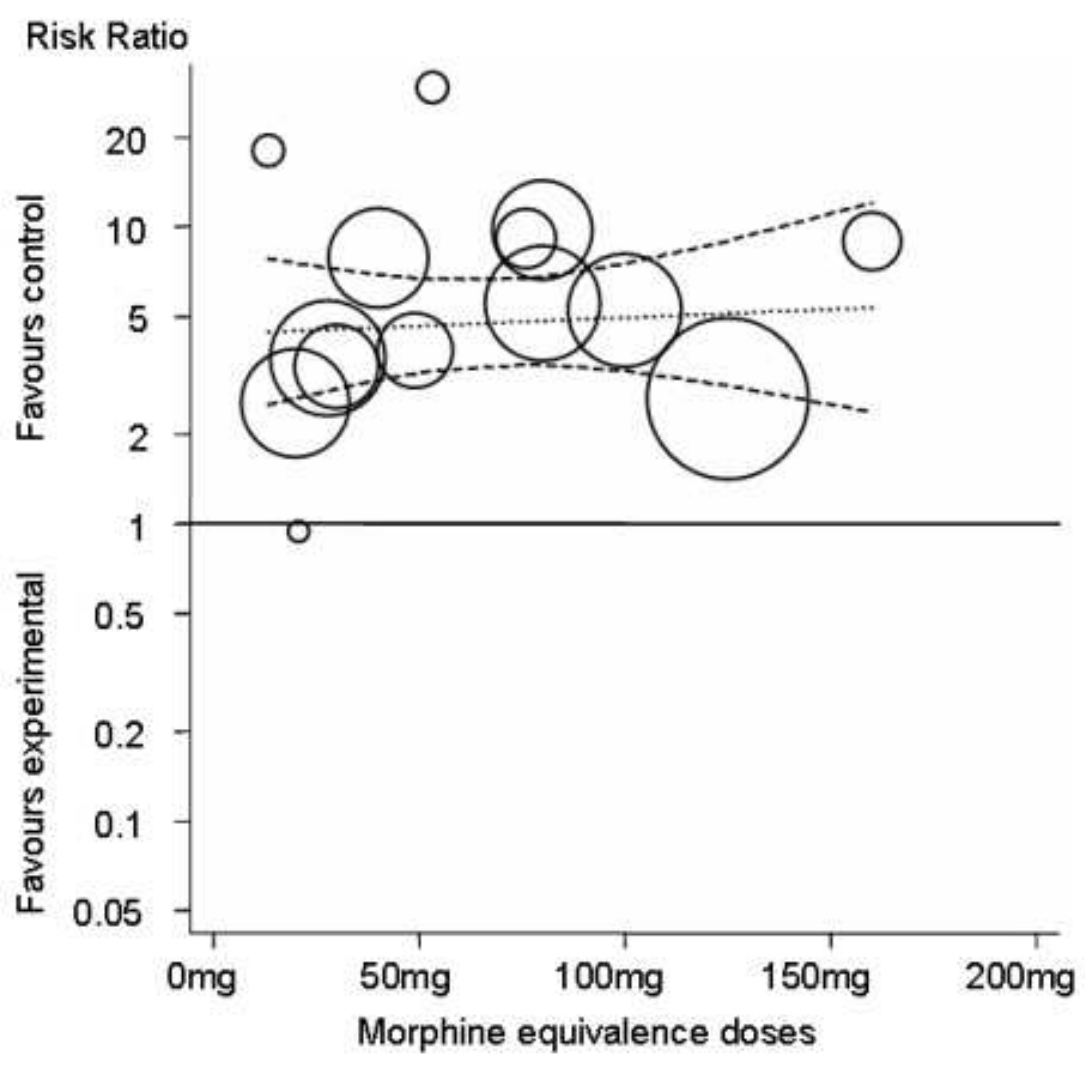


Three trials with 681 patients contributed to the analysis of patients experiencing any serious adverse event (Figure 12). Of the three trials, one trial reported that no patient experienced a serious adverse event (Kjaersgaard-Andersen 1990). Overall data from the remaining two trials indicated that patients receiving opioids tended be more likely to experience a serious adverse event (RR 3.35, $95 \%$ CI 0.83 to 13.56 ). Due to the low number of trials and events, we neither performed an analysis of the association between equivalence dose and log relative risk for this outcome, nor a calculation of NNH to cause one additional patient to experience a serious adverse event compared with placebo. Only one trial contributed to the meta-analysis of symptoms of opioid dependency (Langford 2006). The study assessed opiate withdrawal symptoms after eight weeks of transdermal fentanyl therapy, using the Short Opiate Withdrawal Scale questionnaire (Gossop 1990; Langford 2006). Patients in the fentanyl group reported more severe withdrawal symptoms compared with the placebo group with an SMD of 0.60 (95\% CI 0.42 to 0.79 ), which corresponds to a mean difference on the Short Opiate Withdrawal Scale of 0.27; the scale ranges from 0 to 3 .

Figure 12. Forest plot of 3 trials comparing patients experiencing any adverse event between any opioid and control (placebo or no intervention). Values on $\mathrm{x}$-axis denote risks ratios. The plot is stratified according to type of opioid. The risk ratio in one trial could not be estimated because no serious adverse event occurred in either group.

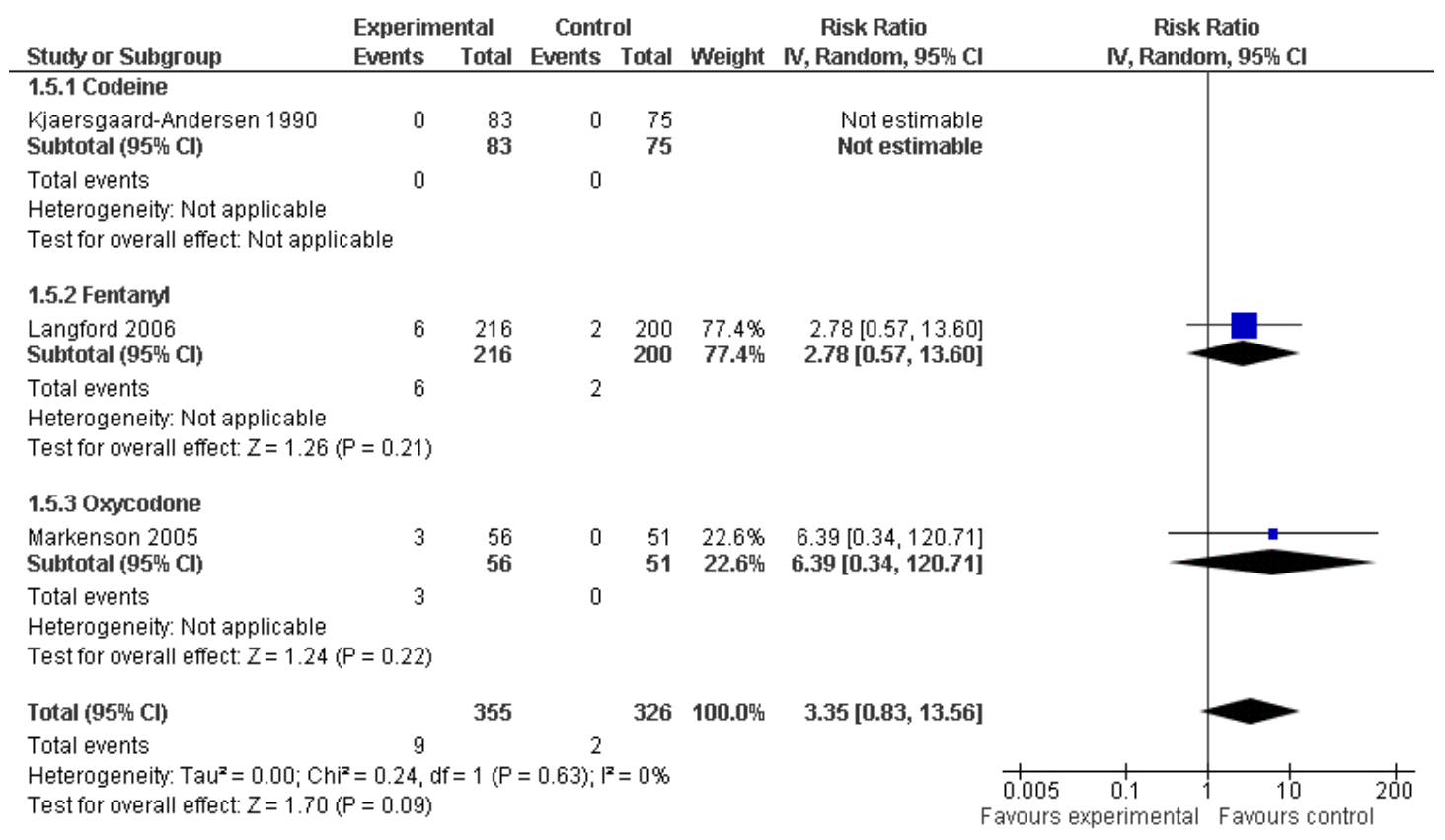




\section{Potential biases in the review process}

We based our review on a broad literature search. Even though we cannot exclude potential publication bias, it seems rather unlikely that we missed relevant trials (Egger 2003). Selection of trials and data extraction were performed independently by two review authors to minimise bias and transcription errors (Egger 2001; Gøtzsche 2007). The most recent systematic review on opioids for osteoarthritis (Avouac 2007), updated in October 2006, considered 18 studies that compared opioids to placebo. We included data from six of these in our meta-analysis and data from four additional trials (Kjaersgaard-Andersen 1990; Quiding 1992; Matsumoto 2005; Kivitz 2006). We excluded six trials with tramadol as the experimental intervention and one trial that was likely to have included only a minority of osteoarthritis patients. In conclusion, we are likely to have included all relevant trials in our systematic review. diction might further limit their use. The reporting of safety outcomes was incomplete and adverse events were reported in four trials, and serious adverse events in three trials only.

\section{Quality of the evidence}

Most of the trials were funded by the pharmaceutical industry and we did not have enough data to explore whether the type of funding was associated with the estimated treatment effects. The effectiveness of opioids may drop after chronic use as the effects of opioids are mediated through opioids receptors. Our analysis of this characteristic was hampered by the low number of studies (two only) reporting opioid use for more than four weeks. The relatively low dose of morphine equivalents (median daily dose $51 \mathrm{mg}$ ) administered in the included trials might provide an explanation of the small benefits observed as compared with other studies (Maier 2002 ). Our ability to provide a reliable assessment of dose dependency might have been hampered by the generally low morphine equivalent doses used and the lack of individual participant data.

Data on risks of addiction due to opioids therapy is scarce, and currently available trials are not designed to evaluate these issues. There is a clear need for additional randomised trials and observational studies using longer follow-up times to address the risks of substance dependence associated with different opioids. In this systematic review only one trial reported measures of the severity of withdrawal symptoms (Langford 2006). Similar to previous systematic reviews of randomised trials on opioids therapy for noncancer pain (Kalso 2004; Furlan 2006), we found that most of the trials included in our review had a treatment duration of several days or a few weeks only. This is too short to address the impact of opioid treatment on routine clinical practice in the treatment of a chronic condition like osteoarthritis. While no evidence of long-term effects is available from randomised trials, observational studies indicate that long-term treatment with opioids of chronic conditions such as osteoarthritis may have deleterious effects and do not seem to improve pain relief (Eriksen 2006).

\section{Agreements and disagreements with other studies or reviews}

We excluded tramadol from our review to avoid overlap with another Cochrane Review that focused on this specific opioid in osteoarthritis (Cepeda 2006). Extracted pain and function outcomes and follow-up time in the previous systematic review about opioids for osteoarthritis (Avouac 2007) were similar to our systematic review. Comparing opioids with placebo controls, Avouac 2007 found a large pooled effects for pain intensity (SMD -0.79, $95 \%$ CI -0.98 to -0.59 ) and a moderate pooled effect for function (SMD - $0.31,95 \%$ CI -0.39 to -0.24 ). These effects are consistent with our results for function but are substantially larger for pain reduction. This discrepancy might be due to the exclusion of some trials in our systematic review. Avouac 2007 reported moderate to large effects of tramadol for pain, between -0.36 to -0.93 standard deviation units, in several large trials and unrealistically large beneficial effects on pain intensity in an oxycodone trial that was excluded from our review (Roth 2000). These trials often did not report function outcomes and could not, therefore, contribute to the pooled analysis, or they reported considerably smaller effects for function than for pain (Avouac 2007). In line with other studies, we found that adverse events occurring in patients treated with opioids often caused withdrawals and dropouts (Kalso 2004; Furlan 2006; Avouac 2007 ). Tramadol may be similar to or even more effective than the opioids evaluated in our review, in reducing pain and improving function, but safety concerns have to be addressed further (Cepeda 2006).

\section{A U THORS'CONCLUSIONS}

\section{Implications for practice}

Opioids decrease pain intensity and improve function but the ben- 
efits observed are small to moderate and increases in doses do not appear to result in further pain reduction. The occurrence of adverse events often caused patients to stop taking the preparations, which is likely to limit their usefulness in the long-term treatment of osteoarthritis of the hip or knee. The higher risk of serious adverse events and the potential occurrence of addiction to opioid therapy might further limit their clinical use. Taken together, our results indicate that the small to moderate beneficial effects of nontramadol opioids are outweighed by large increases in the risk of adverse events. Even in patients with severe osteoarthritic pain, clinicians are advised to use non-tramadol opioids cautiously and to consider alternatives, such as surgery. In addition, clinicians should inform patients about the substantial risks and only moderate benefits of opioid treatment and therapeutic alternatives.

\section{Implications for research}

The effectiveness and safety of opioid and non-opioid analgesics should be directly compared in appropriately powered randomised controlled trials accompanied by network meta-analyses, which integrate direct and indirect evidence in one single analysis while maintaining randomisation (Caldwell 2005). Efficacy and safety data on transdermal opioids are scarce (one trial) suggesting the need for further trials using transdermal preparations. Further trials might be required to better evaluate the effects of the route of administration, the difference between weak and strong opioids, and dose effects. The evidence of the effectiveness and safety of opioid therapy is mainly from a few short-term trials, despite the fact that the underlying condition is chronic and requires safe, long-term treatments (Kalso 2004; Furlan 2006). Further longterm randomised trials or observational studies are needed to increase our understanding of their long-term effectiveness, safety, and the potential for addiction.

\section{ACKNOWLEDGEMENTS}

We thank the Cochrane Musculoskeletal editorial team for valuable comments and Malcolm Sturdy for database support. The authors are grateful to Hans Quiding for providing us with additional information concerning design and outcome data.

\section{RE FER E N C E S}

\section{References to studies included in this review}

Caldwell 2002 \{published data only\}

Caldwell JR, Rapoport RJ, Davis JC, Offenberg HL, Marker HW, Roth $\mathrm{SH}$, et al. Efficacy and safety of a once-daily morphine formulation in chronic, moderate-to-severe osteoarthritis pain: Results from a randomized, placebo-controlled, double-blind trial and an open-label extension trial. Journal of Pain and Symptom Management 2002;23(4):278-91.

Chindalore 2005 \{published data only\} Chindalore VL, Craven RA, Yu KP, Butera PG, Burns LH, Friedmann $\mathrm{N}$. Adding ultra low-dose naltrexone to oxycodone enhances and prolongs analgesia: A randomized, controlled trial of oxytrex. Journal of Pain 2005;6(6):392-9.

\section{Kivitz 2006 \{published data only\}}

Kivitz A, Ma C, Ahdieh H, Galer BS. A 2-week, multicenter, randomized, double-blind, placebo-controlled, dose-ranging, phase III trial comparing the efficacy of oxymorphone extended release and placebo in adults with pain associated with osteoarthritis of the hip or knee. Clinical Therapeutics 2006;28(3):352-64.

\section{Kjaersgaard-Andersen 1990 \{published data only\}}

Kjaersgaard-Andersen P, Nafei A, Skov O, Madsen F, Andersen HM, Kroner $\mathrm{K}$, et al. Codeine plus paracetamol versus paracetamol in longer-term treatment of chronic pain due to osteoarthritis of the hip. A randomised, double-blind, multi-centre study. Pain 1990;43 (3):309-18.

Langford 2006 \{published data only\}

Langford R, McKenna F, Ratcliffe S, Vojtassak J, Richarz U. Transdermal fentanyl for improvement of pain and functioning in os- teoarthritis: A randomized, placebo-controlled trial. Arthritis and Rheumatism 2006;54(6):1829-37.

Markenson 2005 \{published data only\}

Markenson JA, Croft J, Zhang PG, Richards P. Treatment of persistent pain associated with osteoarthritis with controlled-release oxycodone tablets in a randomized controlled clinical trial. Clinical Journal of Pain 2005;21(6):524-35.

\section{Matsumoto 2005 \{published data only\}}

Matsumoto AK, Babul N, Ahdieh H. Oxymorphone extended-release tablets relieve moderate to severe pain and improve physical function in osteoarthritis: Results of a randomized, double-blind, placebo- and active-controlled phase III trial. Pain Medicine 2005;6 (5):357-66.

Peloso 2000 \{published data only\}

Peloso PM, Bellamy N, Bensen W, Thomson GTD, Harsanyi Z, Babul N, et al. Double blind randomized placebo control trial of controlled release codeine in the treatment of osteoarthritis of the hip or knee. Journal of Rheumatology 2000;27(3):764-71.

Quiding 1992 \{published data only\}

Öhrvik, J. Nonparametric methods in crossover trials. Biometrical Journal 1998;7:771-89.

* Quiding H, Grimstad J, Rusten K, Stubhaug A, Bremnes J, Breivik $\mathrm{H}$. Ibuprofen plus codeine, ibuprofen, and placebo in a single- and multidose cross-over comparison for coxarthrosis pain. Pain 1992; 50(3):303-7.

Zautra 2005 \{published data only\}

Zautra AJ, Smith BW. Impact of controlled-release oxycodone on efficacy beliefs and coping efforts among osteoarthritis patients with moderate to severe pain. Clinical Journal of Pain 2005;21(6):471-7. 


\section{References to studies excluded from this review}

Adams 2006 \{published data only\}

Adams EH, Breiner S, Cicero TJ, Geller A, Inciardi JA, Schnoll SH, et al. A comparison of the abuse liability of tramadol, NSAIDs, and hydrocodone in patients with chronic pain. Journal of Pain and Symptom Management 2006;31(5):465-76

Andrei 1984 \{published data only\}

Andrei A, Schiaroli G, Algeri R, Valentini P. Recent data on antiinflammatory and analgesic treatment of degenerative arthropathies. Double-blind controlled clinical trial. [Italian]. Archivio di Medicina Interna 1984;36(4):245-56.

Boureau 1990 \{published data only\}

Boureau F, Delecoeuillerie G, Orvain J. Comparative study of the efficacy and tolerance of 2 dosages of the paracetamol $400 \mathrm{mg}$ codeine $25 \mathrm{mg}$ association versus paracetamol $1000 \mathrm{mg}$ in non-inflammatory rheumatic pain. Rhumatologie Revue International de Rhumatologie 1990;20(1):41-7.

Brooks 1982 \{published data only\}

Brooks PM, Dougan MA, Mugford S, Meffin E. Comparative effectiveness of 5 analgesics in patients with rheumatoid arthritis and osteoarthritis. Journal of Rheumatology 1982;9(5):723-6.

Burch 2004 \{published data only\}

Burch F, Codding C, Patel N, Sheldon E. Lidocaine patch 5\% improves pain, stiffness, and physical function in osteoarthritis pain patients. A prospective, multicenter, open-label effectiveness trial. Osteoarthritis and Cartilage 2004;12(3):253-5.

Caldwell 1999 \{published data only\} Caldwell JR, Hale ME, Boyd RE, Hague JM, Iwan T, Shi M, et al. Treatment of osteoarthritis pain with controlled release oxycodone or fixed combination oxycodone plus acetaminophen added to nonsteroidal antiinflammatory drugs: A double blind, randomized, multicenter, placebo controlled trial. Journal of Rheumatology 1999;26 (4):862-9.

Choquette 2008 \{published data only\}

Choquette D, McCarthy TG, Rodrigues JFN, Kelly AJ, Camacho F, Horbay GLA, et al. Transdermal fentanyl improves pain control and functionality in patients with osteoarthritis: An open-label Canadian trial. Clinical Rheumatology 2008;27(5):587-95.

Doak 1992 \{published data only\}

Doak W, Hosie J, Hossain M, James IGV, Reid I, Miller AJ. A novel combination of ibuprofen and codeine phosphate in the treatment of osteoarthritis: A double-blind placebo controlled study. Journal of Drug Development 1992;4(4):179-87.

Fancourt 1984 \{published data only\}

Fancourt GJ, Flavell Matts SG. A double-blind comparison of meptazinol versus placebo in chronic rheumatoid arthritis and osteoarthritis. Current Medical Research and Opinion 1984;9(3):18491.

Gazi 2005 \{published data only\}

Gazi MCB, Machado Issy A, Kimiko Sakata R. Intra-articular bupivacaine and morphine for knee osteoarthritis analgesia. Comparative study. [Portuguese, English]. Revista Brasileira de Anestesiologia 2005;55(5):491-9.
Hale 2007 \{published data only\}

Hale M, Tudor IC, Khanna S, Thipphawong J. Efficacy and tolerability of once-daily OROS hydromorphone and twice-daily extendedrelease oxycodone in patients with chronic, moderate to severe osteoarthritis pain: Results of a 6-week, randomized, open-label, noninferiority analysis. Clinical Therapeutics 2007;29(5):874-88.

\section{Le Loet 2005 \{published data only\}}

Le Loet X, Pavelka K, Richarz U. Transdermal fentanyl for the treatment of pain caused by osteoarthritis of the knee or hip: An open, multicentre study. BMC Musculoskeletal Disorders 2005;6(31):1-10.

\section{McIlwain 2005 \{published data only\}}

McIlwain H, Ahdieh H. Safety, tolerability, and effectiveness of oxymorphone extended release for moderate to severe osteoarthritis pain: A one-year study. American Journal of Therapeutics 2005;12(2):10612.

\section{Mitchell 1984 \{published data only\}}

Mitchell H, Cunningham TJ, Mathews JD, Muirden KD. Further look at dextropropoxyphene with or without paracetamol in the treatment of arthritis. Medical Journal of Australia 1984;140(4):224-5.

\section{Neubauer 1983 \{published data only\}}

Neubauer M, Bach GL. Short-term therapy of painful muscular disorders. Results of a multicenter double-blind test of 2 new suppository preparations with and without codeine. Fortschritte der Medizin 1983;101(21):1009-13.

\section{Rosenthal 2007 \{published data only\}}

Rosenthal M, Moore P, Groves E, Iwan T, Greenberg Schlosser L, Dziewanowska $Z$, et al. Sleep improves when patients with chronic OA pain are managed with morning dosing of once a day extendrelease morphine sulfate (AVINZA): Findings from a pilot study. Journal of Opioid Management 2007;3(3):145-53.

\section{Roth 2000 \{published data only\}}

Roth SH, Fleischmann RM, Burch FX, Dietz F, Bockow B, Rapoport RJ, et al. Around-the-clock, controlled-release oxycodone therapy for osteoarthritis-related pain: Placebo-controlled trial and long-term evaluation. Archives of Internal Medicine 2000;160(6):853-60.

Salzman 1983 \{published data only\} Salzman RT, Brobyn RD. Long-term comparison of suprofen and propoxyphene in patients with osteoarthritis. Pharmacology 1983; 27 Suppl 1:55-64.

Tassain 2003 \{published data only\}

Tassain V, Attal N, Fletcher D, Brasseur L, Degieux P, Chauvin M, et al. Long term effects of oral sustained release morphine on neuropsychological performance in patients with chronic non-cancer pain. Pain 2003;104(1-2):389-400.

Torres 2001 \{published data only\}

Torres Huerta JC, Hernandez Santos JR, Tenopala Villegas S. Transdermal fentanyl in patients with nononcological chronic pain. [Spanish]. Revista Mexicana de Anestesiologia 2001;24(2):65-8.

\section{Vignon 1999 \{published data only\}}

Vignon E, Bannwarth B, Conrozier T, Derobert E, Verdoncq B. Multicenter, double-blind, clinical trial comparing two tablets bid to one tablet qid of the same acetaminophen-dextropropoxyphen-caffeine combination in patients with osteoarthritis. [French]. Semaine des Hopitaux 1999;75(13-14):419-25. 


\section{Vlok $1987\{$ published data only\}}

Vlok GJ, van Vuren JP. Comparison of a standard ibuprofen treatment regimen with a new ibuprofen/paracetamol/codeine combination in chronic osteo-arthritis. South African Medical Journal [Suid Afrikaanse Tydskrif vir Geneeskunde] 1987;Suppl:1, 4-6.

Wallace 1994 \{published data only\}

Wallace WA, Elliott CA, Price VH. A combination of ibuprofen and codeine phosphate provides superior analgesia to ibuprofen alone in osteoarthritis. British Journal of Clinical Research 1994;5:33-46.

Wang 1965 \{published data only\}

Wang RI. Analgesic effectiveness of new propoxyphene preparations. Journal of New Drugs 1965;5(3):171-6.

\section{References to studies awaiting assessment}

\section{Kroner $1991\{$ published data only\}}

Kroner K, Hansen TB, Harving S, Hvass I, Madsen F, Nafei A, et al. Individually dosed codeine plus paracetamol versus paracetamol in long-term treatment of chronic pain due to arthrosis of the hip A randomised, double blind, multicenter study. Acta Orthopaedica Scandinavica, Supplement 1991;62(246):43.

\section{Additional references}

\section{ACR OA 2000}

American College of Rheumatology Subcommittee on osteoarthritis guidelines. Recommendations for the medical management of osteoarthritis of the hip and knee, 2000 Update. Arthritis and Rheumatism 2000;43:1905-15.

\section{Altman 1986}

Altman R, Asch E, Bloch D, et al. Development of criteria for the classification and reporting of osteoarthritis: classification of osteoarthritis of the knee. Arthritis and Rheumatism 1986;29:1039-49.

Altman 1996

Altman R, Brandt K, Hochberg M, Moskowitz R, Bellamy N, Bloch DA, et al. Design and conduct of clinical trials in patients with osteoarthritis: recommendations from a task force of the Osteoarthritis Research Society. Results from a workshop. Osteoarthritis and Cartilage 1996;4(4):217-43.

Avouac 2007

Avouac J, Gossec L, Dougados M. Efficacy and safety of opioids for osteoarthritis: a meta-analysis of randomized controlled trials. Osteoarthritis and Cartilage 2007;15(8):957-65.

\section{Bellamy 1995}

Bellamy N. Outcome measurement in osteoarthritis clinical trials. The Journal of Rheumatology. Supplement 1995;43:49-51.

\section{Caldwell 2005}

Caldwell DM, Ades AE, Higgins JP. Simultaneous comparison of multiple treatments: combining direct and indirect evidence. $B M J$ 2005;331(7521):897-900.

Cepeda 2006

Cepeda MS, Camargo F, Zea C, Valencia L. Tramadol for osteoarthritis. Cochrane Database of Systematic Reviews 2006;3:CD005522.

\section{Chinn 2000}

Chinn S. A simple method for converting an odds ratio to effect size for use in meta-analysis. Statistics in Medicine 2000;19(22):312731.

\section{Clegg 2006}

Clegg DO, Reda DJ, Harris CL, Klein MA, O’Dell JR, Hooper MM, et al. Glucosamine, chondroitin sulfate, and the two in combination for painful knee osteoarthritis. New England Journal of Medicine 2006;354(8):795-808.

\section{Cohen 1988}

Cohen J. Statistical power analysis for the behavioral sciences. 2nd Edition. Hillsdale, NJ: Lawrence Earlbaum Associates, 1988.

\section{DerSimonian 1986}

DerSimonian R, Laird N. Meta-analysis in clinical trials. Controlled Clinical Trials 1986;7(3):177-88.

\section{Dickersin 1994}

Dickersin K, Scherer R, Lefebvre C. Identifying relevant studies for systematic reviews. BMJ 1994;309(6964):1286-91.

\section{Eccles 1998}

Eccles M, Freemantle N, Mason J. North of England Evidence Based Guidelines Development Project: summary guideline for nonsteroidal anti-inflammatory drugs versus basic analgesics in treating of pain of degenerative arthritis. BMJ 1998;317:526-30.

Egger 2001

Egger M, Smith GD. Principles of and procedures for systematic reviews. In: Egger M, Smith GD, Altman DG editor(s). Systematic Reviews in Health Care: Meta-Analysis in Context. London: BMJ Books, 2001:23-42.

\section{Egger 2003}

Egger M, Juni P, Bartlett C, Holenstein F, Sterne J. How important are comprehensive literature searches and the assessment of trial quality in systematic reviews? Empirical study. Health Technology Assessment (Winchester, England) 2003;7(1):1-76.

\section{Eriksen 2006}

Eriksen J, Sjøgren P, Bruera E, Ekholm O, Rasmussen NK. Critical issues on opioids in chronic non-cancer pain: an epidemiological study. Pain 2006;125(1-2):172-9.

\section{Furlan 2006}

Furlan AD, Sandoval JA, Mailis-Gagnon A, Tunks E. Opioids for chronic noncancer pain: a meta-analysis of effectiveness and side effects. Canadian Medical Association Journal 2006;1(11):1589-94.

\section{Gossop 1990}

Gossop M. The development of a Short Opiate Withdrawal Scale (SOWS). Addictive Behaviors 1990;15(5):487-90.

\section{Guyatt 2008}

Guyatt G, Oxman AD, Vist GE, Kunz R, Falck-Ytter Y, AlonsoCoello P, Schunemann HJ, GRADE Working Group. GRADE: an emerging consensus on rating quality of evidence and strength of recommendations. BMJ 2008;336(7650):924-6.

\section{Gøtzsche 2007}

Gøtzsche PC, Hróbjartsson A, Maric K, Tendal B. Data extraction errors in meta-analyses that use standardized mean differences. JAMA 2007;298(4):430-7.

\section{Higgins 2003}

Higgins JP, Thompson SG, Deeks JJ, Altman DG. Measuring inconsistency in meta-analyses. BMJ 2003;327(7414):557-60. 


\section{Higgins 2008}

Higgins JPT, Green S (editors). Cochrane Handbook for Systematic Reviews of Interventions. Version 5.0.1. The Cochrane Collaboration, 2008.

Jüni 2001

Juni P, Altman DG, Egger M. Systematic reviews in health care: Assessing the quality of controlled clinical trials. BMJ 2001;323 (7303):42-6.

\section{Jüni 2006}

Juni P, Reichenbach S, Dieppe P. Osteoarthritis: rational approach to treating the individual. Best Practice \& Research. Clinical Rheumatology 2006;20(4):721-40.

\section{Kalso 2004}

Kalso E, Edwards JE, Moore RA, McQuay HJ. Opioids in chronic non-cancer pain: systematic review of efficacy and safety. Pain 2004; 112(3):372-80.

\section{Loeser 2001}

Loser JD, Butler SH, Chapman CR, Turk DC. Bonica's Managment of Pain. 3rd Edition. Lippincott Williams \& Wilkins, 2001.

\section{Maier 2002}

Maier C, Hildebrandt J, Klinger R, Henrich-Eberl C, Lindena G, MONTAS Study Group. Morphine responsiveness, efficacy and tolerability in patients with chronic non-tumor associated pain - results of a double-blind placebo-controlled trial (MONTAS). Pain 2002; 97(3):223-33.

\section{Nüesch 2009}

Nuesch E, Trelle S, Reichenbach S, Rutjes AWS, Burgi E, Scherer $\mathrm{M}$, et al. The effects of the exclusion of patients from the analysis in randomised controlled trials: meta-epidemiological study. BMJ 2009; in press:..

\section{Pham 2004}

Pham T, van der Heijde D, Altman RD, Anderson JJ, Bellamy N, Hochberg M, et al. OMERACT-OARSI initiative: Osteoarthritis Research Society International set of responder criteria for osteoarthritis clinical trials revisited. Osteoarthritis and Cartilage 2004; 12(5):389-99.

\section{Reichenbach 2007}

Reichenbach S, Sterchi R, Scherer M, Trelle S, Burgi E, Burgi U, et al. Meta-analysis: chondroitin for osteoarthritis of the knee or hip. Annals of Internal Medicine 2007;146(8):580-90.

\section{Rücker 2008}

Rucker G, Schwarzer G, Carpenter JR, Schumacher M. Undue reliance on $\mathrm{I}(2)$ in assessing heterogeneity may mislead. BMC Medical Research Methodology 2008;8(1):79.

\section{Schug 2006}

Schug SA, Gandham N. Opioids: clinical use. In: McMahon S, Klotzenburg M editor(s). Wall and Melzack's Textbook of Pain. 5th Edition. Elsevier Limited, 2006:443-57.

\section{Shang 2005}

Shang A, Huwiler-Muntener K, Nartey L, Juni P, Dorig S, Sterne JA, et al. Are the clinical effects of homoeopathy placebo effects? Comparative study of placebo-controlled trials of homoeopathy and allopathy. Lancet 2005;366(9487):726-32.

\section{Stein 1996}

Stein C, Pfluger M, Yassouridis A, et al. No tolerance to peripheral morphine analgesia in presence of opioid expression in inflamed synovia. Journal of Clinical Investigation 1996;98:793-9.

\section{Sterne 2001}

Sterne JA, Egger M. Funnel plots for detecting bias in meta-analysis: guidelines on choice of axis. Journal of Clinical Epidemiology 2001; 54(10):1046-55.

\section{Thompson 1999}

Thompson SG, Sharp SJ. Explaining heterogeneity in meta-analysis: a comparison of methods. Statistics in Medicine 1999;18(20):2693708.

\section{Von Korff 2004}

Von Korff M, Deyo RA. Potent opioids for chronic musculoskeletal pain: flying blind?. Pain 2004;109(3):207-9.

\section{Zhang 2008}

Zhang W, Moskowitz RW, Nuki G, Abramson S, Altman RD, Arden $\mathrm{N}$, et al. OARSI recommendations for the management of hip and knee osteoarthritis, Part II: OARSI evidence-based, expert consensus guidelines. Osteoarthritis and Cartilage 2008;16(2):137-62.

* Indicates the major publication for the study 


\section{CHARACTERISTICS OF STUDIES}

\section{Characteristics of included studies [ordered by study ID]}

Caldwell 2002

\begin{tabular}{|c|c|c|}
\hline Methods & \multicolumn{2}{|c|}{$\begin{array}{l}\text { Randomised controlled trial } \\
\text { 4-arm parallel group design } \\
\text { Trial duration: } 4 \text { weeks } \\
\text { Multicentre trial } \\
\text { No power calculation reported }\end{array}$} \\
\hline Participants & \multicolumn{2}{|c|}{$\begin{array}{l}\text { Patients with prior suboptimal analgesic response to NSAIDs/paracetamol or previous } \\
\text { intermittent opioid therapy were eligible } \\
295 \text { patients with knee and/or hip osteoarthritis were reported at baseline } \\
\text { Number of females: } 184 \text { of } 295 \text { ( } 62 \%) \\
\text { Average age: } 62 \text { years }\end{array}$} \\
\hline Interventions & \multicolumn{2}{|c|}{$\begin{array}{l}\text { Experimental interventions } \\
\text { a) oral morphine (Avinza), } 30 \mathrm{mg} \text { once daily in the morning } \\
\text { b) oral morphine (Avinza), } 30 \mathrm{mg} \text { once daily in the evening } \\
\text { c) oral morphine sulphate (Contin), } 15 \mathrm{mg} \text { twice daily } \\
\text { Control intervention } \\
\text { Placebo, twice daily } \\
\text { Treatment duration: } 4 \text { weeks } \\
\text { No analgesics other than study drugs allowed }\end{array}$} \\
\hline Outcomes & \multicolumn{2}{|c|}{$\begin{array}{l}\text { Extracted pain outcome: global pain after } 4 \text { weeks } \\
\text { Extracted function outcome: WOMAC disability subscore after } 4 \text { weeks } \\
\text { Primary outcome: WOMAC OA index }\end{array}$} \\
\hline \multicolumn{3}{|l|}{ Notes } \\
\hline \multicolumn{3}{|l|}{ Risk of bias } \\
\hline Item & Authors' judgement & Description \\
\hline Adequate sequence generation? & Unclear & No information provided. \\
\hline Allocation concealment? & Unclear & No information provided. \\
\hline Described as double-blind? & Yes & \\
\hline Blinding of patients? & Yes & \\
\hline Blinding of physicians? & Unclear & No information provided. \\
\hline
\end{tabular}




\section{Caldwell 2002 (Continued)}

\begin{tabular}{l|ll}
\hline Blinding of outcome assessors? & Yes & \\
\hline $\begin{array}{l}\text { Interventions reported as indistinguish- } \\
\text { able? }\end{array}$ & No & \\
\hline $\begin{array}{l}\text { Double-dummy technique used? } \\
\begin{array}{l}\text { Intention-to-treat analysis performed? } \\
\text { Pain }\end{array}\end{array}$ & Yes & No information on exclusions available. \\
\hline $\begin{array}{l}\text { Intention-to-treat analysis performed? } \\
\text { Function }\end{array}$ & No & No information on exclusions available. \\
\hline \begin{tabular}{l} 
No funding by commercial organisation? \\
\hline
\end{tabular} & No & Sponsor: Elan \\
\hline
\end{tabular}

\section{Chindalore 2005}

\begin{tabular}{ll}
\hline Methods & $\begin{array}{l}\text { Randomised controlled trial } \\
\text { 4-arm parallel group design } \\
\text { Trial duration: } 4 \text { weeks } \\
\text { Randomisation stratified according to gender } \\
\text { Multicentre trial with } 37 \text { centres } \\
\text { No power calculation reported }\end{array}$ \\
\hline Participants & $\begin{array}{l}\text { Patients with moderate to severe hip or knee pain while taking } \geq 1 \text { oral analgesic medi- } \\
\text { cation were eligible } \\
\text { 362 patients were randomised } \\
360 \text { patients with hip or knee osteoarthritis were reported at baseline } \\
\text { Number of females: } 249 \text { of 360 (69\%) } \\
\text { Average age: } 54 \text { years }\end{array}$ \\
\hline Interventions & $\begin{array}{l}\text { Experimental interventions } \\
\text { a) oral oxycodone, } 10 \mathrm{mg} 4 \text {-times daily } \\
\text { b) oral oxycodone, } 2.5 \mathrm{mg} 4 \text {-times daily, plus naltrexone, } 0.001 \text { mg } 4 \text {-times daily } \\
\text { (Oxytrex) } \\
\text { c) oral oxycodone, } 2.5 \mathrm{mg} 4 \text {-times daily, plus natronex, } 0.001 \text { mg twice daily (Oxytrex) } \\
\text { Control intervention } \\
\text { Placebo, twice daily } \\
\text { Treatment duration: } 3 \text { weeks } \\
\text { Analgesics other than study drugs allowed, but it was unclear whether intake was similar } \\
\text { between groups }\end{array}$ \\
\hline
\end{tabular}


Chindalore 2005 (Continued)

\begin{tabular}{|c|c|c|}
\hline Outcomes & \multicolumn{2}{|c|}{$\begin{array}{l}\text { Extracted pain outcome: global pain after } 4 \text { weeks } \\
\text { Extracted function outcome: WOMAC disability subscore after } 4 \text { weeks } \\
\text { Primary outcome: pain intensity during the past } 24 \text { hours }\end{array}$} \\
\hline Notes & \multicolumn{2}{|c|}{$\begin{array}{l}\text { For WOMAC disability, insufficient data were reported to calculate standardised mean } \\
\text { differences and it was therefore not included in the meta-analysis }\end{array}$} \\
\hline \multicolumn{3}{|l|}{ Risk of bias } \\
\hline Item & Authors' judgement & Description \\
\hline Adequate sequence generation? & Unclear & No information provided. \\
\hline Allocation concealment? & Unclear & No information provided. \\
\hline Described as double-blind? & Yes & \\
\hline Blinding of patients? & Yes & \\
\hline Blinding of physicians? & Yes & \\
\hline Blinding of outcome assessors? & Yes & \\
\hline $\begin{array}{l}\text { Interventions reported as indistinguish- } \\
\text { able? }\end{array}$ & Yes & \\
\hline Double-dummy technique used? & No & \\
\hline $\begin{array}{l}\text { Intention-to-treat analysis performed? } \\
\text { Pain }\end{array}$ & No & $\begin{array}{l}1 \text { of } 310 \text { patients }(0.3 \%) \text { excluded in experimental groups, } 1 \text { of } \\
52 \text { patients }(1.9 \%) \text { excluded in control group. }\end{array}$ \\
\hline $\begin{array}{l}\text { Intention-to-treat analysis performed? } \\
\text { Function }\end{array}$ & No & $\begin{array}{l}1 \text { of } 310 \text { patients }(0.3 \%) \text { excluded in experimental groups, } 1 \text { of } \\
52(1.9 \%) \text { patients excluded in control group. }\end{array}$ \\
\hline No funding by commercial organisation? & No & Sponsor: Pain Therapeutics \\
\hline
\end{tabular}


Kivitz 2006

\begin{tabular}{ll}
\hline Methods & $\begin{array}{l}\text { Randomised controlled trial } \\
\text { 4-arm parallel group design } \\
\text { Trial duration: } 2 \text { weeks } \\
\text { Multicentre trial } \\
\text { Power calculation reported }\end{array}$ \\
\hline Participants & $\begin{array}{l}\text { Patients with suboptimal analgesic response to NSAIDs/paracetamol or previous opioid } \\
\text { therapy were eligible } \\
370 \text { patients were randomised } \\
370 \text { patients with knee or hip osteoarthritis were reported at baseline } \\
\text { Affected joints: } 297 \text { knees and } 73 \text { hips } \\
\text { Number of females: } 224 \text { of } 370(61 \%)\end{array}$ \\
\hline
\end{tabular}

Experimental interventions
a) oral extended-release oxymorphone, $10 \mathrm{mg}$ twice daily
b) oral extended-release oxymorphone, $40 \mathrm{mg}$ twice daily
c) oral extended-release oxymorphone, $50 \mathrm{mg}$ twice daily
Control intervention
Placebo, twice daily
Treatment duration: 2 weeks
No analgesics other than study drugs allowed.

Outcomes

Extracted pain outcome: global pain after 2 weeks.

Extracted function outcome: WOMAC disability subscore after 2 weeks

Primary outcome: change in pain intensity

Notes

Risk of bias

\begin{tabular}{|c|c|c|}
\hline Item & Authors' judgement & Description \\
\hline Adequate sequence generation? & Yes & \\
\hline Allocation concealment? & Yes & \\
\hline Described as double-blind? & Yes & \\
\hline Blinding of patients? & Yes & \\
\hline Blinding of physicians? & Yes & \\
\hline Blinding of outcome assessors? & Yes & \\
\hline $\begin{array}{l}\text { Interventions reported as indistinguish- } \\
\text { able? }\end{array}$ & No & \\
\hline
\end{tabular}


Kivitz 2006 (Continued)

\begin{tabular}{|c|c|c|}
\hline Double-dummy technique used? & Yes & \\
\hline $\begin{array}{l}\text { Intention-to-treat analysis performed? } \\
\text { Pain }\end{array}$ & No & $\begin{array}{l}9 \text { of } 279 \text { patients }(0.7 \%) \text { excluded in experimental groups, } 4 \text { of } \\
91 \text { patients }(4.4 \%) \text { excluded in control group. }\end{array}$ \\
\hline $\begin{array}{l}\text { Intention-to-treat analysis performed? } \\
\text { Function }\end{array}$ & No & $\begin{array}{l}9 \text { of } 279 \text { patients }(0.7 \%) \text { excluded in experimental groups, } 4 \text { of } \\
91 \text { patients }(4.4 \%) \text { excluded in control group. }\end{array}$ \\
\hline No funding by commercial organisation? & No & $\begin{array}{l}\text { Sponsor: Endo Pharmaceuticals Inc, Penwest Pharmaceuticals } \\
\text { Co. }\end{array}$ \\
\hline
\end{tabular}

\section{Kjaersgaard-Andersen 1990}

\begin{tabular}{|c|c|c|}
\hline Methods & \multicolumn{2}{|c|}{$\begin{array}{l}\text { Randomised controlled trial } \\
\text { 2-arm parallel group design } \\
\text { Trial duration: } 4 \text { weeks } \\
\text { Multicentre trial with } 7 \text { centres } \\
\text { Power calculation reported }\end{array}$} \\
\hline Participants & \multicolumn{2}{|c|}{$\begin{array}{l}\text { Patients with chronic pain requiring analgesic treatment were eligible } \\
158 \text { patients with hip osteoarthritis were reported at baseline } \\
\text { Affected joints: } 158 \text { hips } \\
\text { Number of females: } 72 \text { of } 158(46 \%) \\
\text { Average age: } 66 \text { years } \\
\text { Average BMI: } 26 \mathrm{~kg} / \mathrm{m}^{2}\end{array}$} \\
\hline Interventions & \multicolumn{2}{|c|}{$\begin{array}{l}\text { Experimental intervention } \\
\text { Oral codeine } 60 \mathrm{mg} \text { plus paracetamol } 1000 \mathrm{mg}, 3 \text { times daily } \\
\text { Control intervention } \\
\text { Paracetamol } 1000 \mathrm{mg}, 3 \text { times daily } \\
\text { Treatment duration: } 4 \text { weeks } \\
\text { No analgesics other than study drugs allowed }\end{array}$} \\
\hline Outcomes & \multicolumn{2}{|c|}{$\begin{array}{l}\text { Extracted pain outcome: global pain after } 4 \text { weeks } \\
\text { Extracted function outcome: patient's global assessment after } 4 \text { weeks }\end{array}$} \\
\hline \multicolumn{3}{|l|}{ Notes } \\
\hline \multicolumn{3}{|l|}{ Risk of bias } \\
\hline Item & Authors' judgement & Description \\
\hline Adequate sequence generation? & Unclear & No information provided. \\
\hline
\end{tabular}


Kjaersgaard-Andersen 1990 (Continued)

\begin{tabular}{|c|c|c|}
\hline Allocation concealment? & Unclear & No information provided. \\
\hline Described as double-blind? & Yes & \\
\hline Blinding of patients? & Yes & \\
\hline Blinding of physicians? & Unclear & No information provided. \\
\hline Blinding of outcome assessors? & Yes & \\
\hline $\begin{array}{l}\text { Interventions reported as indistinguish- } \\
\text { able? }\end{array}$ & Yes & \\
\hline Double-dummy technique used? & No & \\
\hline $\begin{array}{l}\text { Intention-to-treat analysis performed? } \\
\text { Pain }\end{array}$ & No & $\begin{array}{l}43 \text { of } 83 \text { patients (52\%) excluded in experimental group, } 18 \text { of } \\
75 \text { patients }(24 \%) \text { excluded in control group. }\end{array}$ \\
\hline $\begin{array}{l}\text { Intention-to-treat analysis performed? } \\
\text { Function }\end{array}$ & No & $\begin{array}{l}40 \text { of } 83 \text { patients ( } 48 \%) \text { excluded in experimental group, } 15 \text { of } \\
75 \text { patients }(20 \%) \text { excluded in control group. }\end{array}$ \\
\hline No funding by commercial organisation? & Unclear & No information provided. \\
\hline
\end{tabular}

\section{Langford 2006}

\begin{tabular}{|c|c|}
\hline Methods & $\begin{array}{l}\text { Randomised controlled trial } \\
\text { 2-arm parallel group design } \\
\text { Trial duration: } 8 \text { weeks } \\
\text { Randomisation stratified according to target joint (knee/hip) } \\
\text { Multicentre trial } \\
\text { Power calculation reported }\end{array}$ \\
\hline Participants & $\begin{array}{l}\text { Patients without adequate pain control under weak opioid treatment (with and without } \\
\text { paracetamol) were eligible } \\
416 \text { patients were randomised } \\
399 \text { patients with knee or hip osteoarthritis were reported at baseline } \\
\text { Affected joints: } 211 \text { knees and } 188 \text { hips } \\
\text { Number of females: } 265 \text { of } 399(66 \%)\end{array}$ \\
\hline Interventions & $\begin{array}{l}\text { Experimental intervention } \\
\text { Transdermal fentanyl (Durogesic), median dosage } 25 \mu \mathrm{g} / \text { hour } \\
\text { Control intervention } \\
\text { Placebo } \\
\text { Treatment duration: } 6 \text { weeks }\end{array}$ \\
\hline
\end{tabular}




\section{Langford 2006 (Continued)}

Analgesics other than study drugs allowed and intake assessed, but unclear whether intake was similar between groups

\begin{tabular}{|c|c|c|}
\hline Outcomes & \multicolumn{2}{|c|}{$\begin{array}{l}\text { Extracted pain outcome: global pain after } 8 \text { weeks } \\
\text { Extracted function outcome: WOMAC disability subscore after } 8 \text { weeks } \\
\text { Primary outcome: pain relief on VAS }\end{array}$} \\
\hline \multicolumn{3}{|l|}{ Notes } \\
\hline \multicolumn{3}{|l|}{ Risk of bias } \\
\hline Item & Authors' judgement & Description \\
\hline Adequate sequence generation? & Yes & \\
\hline Allocation concealment? & Yes & \\
\hline Described as double-blind? & Yes & \\
\hline Blinding of patients? & Yes & \\
\hline Blinding of physicians? & Yes & \\
\hline Blinding of outcome assessors? & Unclear & No information provided. \\
\hline $\begin{array}{l}\text { Interventions reported as indistinguish- } \\
\text { able? }\end{array}$ & Yes & \\
\hline Double-dummy technique used? & No & \\
\hline $\begin{array}{l}\text { Intention-to-treat analysis performed? } \\
\text { Pain }\end{array}$ & No & No information on exclusions available. \\
\hline $\begin{array}{l}\text { Intention-to-treat analysis performed? } \\
\text { Function }\end{array}$ & No & No information on exclusions available. \\
\hline No funding by commercial organisation? & No & Sponsor: Janssen-Cilag \\
\hline
\end{tabular}




\begin{tabular}{|c|c|c|}
\hline Methods & \multicolumn{2}{|c|}{$\begin{array}{l}\text { Randomised controlled trial } \\
\text { 2-arm parallel group design } \\
\text { Trial duration: } 13 \text { weeks } \\
\text { Multicentre trial with } 9 \text { centres } \\
\text { Power calculation reported }\end{array}$} \\
\hline Participants & \multicolumn{2}{|c|}{$\begin{array}{l}\text { Patients with moderate to severe pain while taking NSAIDs/paracetamol, with con } \\
\text { traindications to NSAID therapy or with previous oral opioid therapy were eligible } \\
109 \text { patients were randomised } \\
107 \text { patients with osteoarthritis were reported at baseline } \\
\text { Affected joints: } 33 \text { knees, } 19 \text { hips, and } 57 \text { other joints } \\
\text { Number of females: } 78 \text { of } 107(73 \%) \\
\text { Average age: } 63 \text { years }\end{array}$} \\
\hline Interventions & \multicolumn{2}{|c|}{$\begin{array}{l}\text { Experimental intervention } \\
\text { Oral oxycodone (OxyContin), 10mg twice daily } \\
\text { Control intervention } \\
\text { Placebo, twice daily } \\
\text { Treatment duration: } 13 \text { weeks } \\
\text { Analgesics other than study drugs allowed and intake assessed, but unclear whether intake } \\
\text { was similar }\end{array}$} \\
\hline Outcomes & \multicolumn{2}{|c|}{$\begin{array}{l}\text { Extracted pain outcome: global pain after } 13 \text { weeks } \\
\text { Extracted function outcome: WOMAC global scale after } 13 \text { weeks }\end{array}$} \\
\hline \multicolumn{3}{|l|}{ Notes } \\
\hline \multicolumn{3}{|l|}{ Risk of bias } \\
\hline Item & Authors' judgement & Description \\
\hline Adequate sequence generation? & Yes & \\
\hline Allocation concealment? & Yes & \\
\hline Described as double-blind? & Yes & \\
\hline Blinding of patients? & Yes & \\
\hline Blinding of physicians? & Yes & \\
\hline Blinding of outcome assessors? & Yes & \\
\hline
\end{tabular}

Interventions reported as indistinguish- Yes able? 
Markenson 2005 (Continued)

\begin{tabular}{|c|c|c|}
\hline Double-dummy technique used? & No & \\
\hline $\begin{array}{l}\text { Intention-to-treat analysis performed? } \\
\text { Pain }\end{array}$ & No & No information on exclusions available. \\
\hline $\begin{array}{l}\text { Intention-to-treat analysis performed? } \\
\text { Function }\end{array}$ & No & No information on exclusions available. \\
\hline No funding by commercial organisation? & No & Sponsor: Purdue Pharma \\
\hline
\end{tabular}

\section{Matsumoto 2005}

\begin{tabular}{ll}
\hline Methods & Randomised controlled trial \\
& 4-arm parallel group design \\
& Trial duration: 4 weeks \\
Simple randomisation & Multicentre trial \\
& Power calculation reported \\
\hline Participants & Patients with suboptimal analgesic response to NSAIDs, paracetamol, or opioids were \\
& eligible \\
& 491 patients were randomised \\
& 489 patients with OA were reported at baseline \\
& Affected joints: $373 \mathrm{knees}$ and $116 \mathrm{hips}$ \\
& Number of females: 297 of $489(61 \%)$ \\
Average age: 62 years & Average BMI: $34 \mathrm{~kg} / \mathrm{m}^{2}$ \\
\hline
\end{tabular}

Interventions

Experimental interventions

a) Oral extended-release oxymorphone, $20 \mathrm{mg}$ twice daily

b) Oral extended-release oxymorphone, $40 \mathrm{mg}$ twice daily

c) Oral controlled-release oxycodone, $20 \mathrm{mg}$ twice daily

Control intervention

Placebo, twice daily

Treatment duration: 4 weeks

No analgesics other than study drugs allowed

Outcomes

Extracted pain outcome: WOMAC pain subscore after 4 weeks

Extracted function outcome: WOMAC disability subscore after 4 weeks

Primary outcome: change in arthritis pain intensity

Notes

Risk of bias 
Matsumoto 2005 (Continued)

\begin{tabular}{|c|c|c|}
\hline Item & Authors' judgement & Description \\
\hline Adequate sequence generation? & Yes & \\
\hline Allocation concealment? & Unclear & No information provided. \\
\hline Described as double-blind? & Yes & \\
\hline Blinding of patients? & Yes & \\
\hline Blinding of physicians? & Yes & \\
\hline Blinding of outcome assessors? & Yes & \\
\hline $\begin{array}{l}\text { Interventions reported as indistinguish- } \\
\text { able? }\end{array}$ & Yes & \\
\hline Double-dummy technique used? & No & \\
\hline $\begin{array}{l}\text { Intention-to-treat analysis performed? } \\
\text { Pain }\end{array}$ & No & $\begin{array}{l}19 \text { of } 367 \text { patients }(5.2 \%) \text { excluded in experimental groups, } 5 \\
\text { of } 124(4.0 \%) \text { patients excluded in control group. }\end{array}$ \\
\hline $\begin{array}{l}\text { Intention-to-treat analysis performed? } \\
\text { Function }\end{array}$ & No & $\begin{array}{l}19 \text { of } 367 \text { patients (5.2\%) excluded in experimental groups, } 5 \\
\text { of } 124(4.0 \%) \text { patients excluded in control group. }\end{array}$ \\
\hline No funding by commercial organisation? & No & $\begin{array}{l}\text { Sponsors: TheraQuest Biosciences, Endo Pharmaceuticals, Pen- } \\
\text { west Pharmaceuticals Co. }\end{array}$ \\
\hline
\end{tabular}

Peloso 2000

\begin{tabular}{l|l}
\hline Methods & $\begin{array}{l}\text { Randomised controlled trial } \\
\text { 2-arm parallel group design } \\
\text { Trial duration: } 4 \text { weeks } \\
\text { Multicentre trial with } 4 \text { centres } \\
\text { Power calculation reported }\end{array}$ \\
\hline Participants & Patients with osteoarthritis symptoms requiring therapy with paracetamol, anti-inflam- \\
matory agents or opioids were eligible. \\
103 patients were randomised \\
103 patients with osteoarthritis were reported at baseline \\
Affected joints: $94 \mathrm{knees}$ and 49 hips \\
Number of females: 64 of $103(62 \%)$ \\
Average age: 62 years \\
Average BMI: $34 \mathrm{~kg} / \mathrm{m}^{2}$
\end{tabular}


Peloso 2000 (Continued)

Average disease duration: 10.3 years

\begin{tabular}{ll}
\hline Interventions & $\begin{array}{l}\text { Experimental intervention } \\
\text { Oral codeine (Contin), 100mg twice daily } \\
\text { Control intervention } \\
\text { Placebo, twice daily } \\
\text { Treatment duration: } 4 \text { weeks } \\
\text { Analgesics other than study drugs allowed and intake assessed, but unclear whether intake } \\
\text { was similar between groups }\end{array}$ \\
\hline Outcomes & Extracted pain outcome: global pain after 4 weeks \\
& Extracted function outcome: WOMAC disability subscore after 4 weeks \\
& Primary outcome: WOMAC pain and overall pain intensity \\
\hline Notes & \\
\hline
\end{tabular}

Risk of bias

\begin{tabular}{|c|c|c|}
\hline Item & Authors' judgement & Description \\
\hline Adequate sequence generation? & Unclear & No information provided. \\
\hline Allocation concealment? & Unclear & No information provided. \\
\hline Described as double-blind? & Yes & \\
\hline Blinding of patients? & Yes & \\
\hline Blinding of physicians? & Unclear & No information provided. \\
\hline Blinding of outcome assessors? & Unclear & No information provided. \\
\hline $\begin{array}{l}\text { Interventions reported as indistinguish- } \\
\text { able? }\end{array}$ & Yes & \\
\hline Double-dummy technique used? & No & \\
\hline $\begin{array}{l}\text { Intention-to-treat analysis performed? } \\
\text { Pain }\end{array}$ & No & $\begin{array}{l}20 \text { of } 51 \text { patients (39\%) excluded in experimental group, } 17 \text { of } \\
52 \text { patients (33\%) excluded in control group. }\end{array}$ \\
\hline $\begin{array}{l}\text { Intention-to-treat analysis performed? } \\
\text { Function }\end{array}$ & No & $\begin{array}{l}20 \text { of } 51 \text { patients (39\%) excluded in experimental group, } 17 \text { of } \\
52 \text { patients (33\%) excluded in control group. }\end{array}$ \\
\hline No funding by commercial organisation? & No & Sponsor: Purdue Frederick \\
\hline
\end{tabular}


Quiding 1992

\begin{tabular}{|c|c|c|}
\hline Methods & \multicolumn{2}{|c|}{$\begin{array}{l}\text { Randomised controlled trial } \\
\text { 3-arm crossover design } \\
\text { Trial duration: } 1 \text { week } \\
\text { No power calculation reported }\end{array}$} \\
\hline Participants & \multicolumn{2}{|c|}{$\begin{array}{l}\text { Patients in need of analgesic medication for hip osteoarthritis were eligible } \\
27 \text { patients were randomised } \\
26 \text { patients with OA were reported at baseline } \\
\text { Affected joints: } 26 \text { hips } \\
\text { Number of females: } 22 \text { of } 26(85 \%) \\
\text { Average age: } 53 \text { years }\end{array}$} \\
\hline Interventions & \multicolumn{2}{|c|}{$\begin{array}{l}\text { Experimental intervention } \\
30 \text { mg oral codeine plus } 200 \mathrm{mg} \text { ibuprofen, } 6 \text { times in } 32 \text { hours } \\
\text { Control intervention } \\
200 \mathrm{mg} \text { ibuprofen, } 6 \text { times in } 32 \text { hours } \\
\text { Treatment duration: } 32 \text { hours } \\
\text { No analgesics other than study drugs allowed }\end{array}$} \\
\hline Outcomes & \multicolumn{2}{|c|}{$\begin{array}{l}\text { Extracted pain outcome: global pain after } 1 \text { week } \\
\text { No function outcome reported } \\
\text { No primary outcome reported }\end{array}$} \\
\hline Notes & \multicolumn{2}{|c|}{1 trial arm excluded from review } \\
\hline \multicolumn{3}{|l|}{ Risk of bias } \\
\hline Item & Authors' judgement & Description \\
\hline Adequate sequence generation? & Unclear & No information provided. \\
\hline Allocation concealment? & Unclear & No information provided. \\
\hline Described as double-blind? & Yes & \\
\hline Blinding of patients? & Yes & \\
\hline Blinding of physicians? & Unclear & No information provided. \\
\hline Blinding of outcome assessors? & Yes & \\
\hline $\begin{array}{l}\text { Interventions reported as indistinguish- } \\
\text { able? }\end{array}$ & No & \\
\hline Double-dummy technique used? & Yes & \\
\hline
\end{tabular}


Quiding 1992 (Continued)

\begin{tabular}{lll}
\hline $\begin{array}{l}\text { Intention-to-treat analysis performed? } \\
\text { Pain }\end{array}$ & Unclear & No information on exclusions available. \\
\hline $\begin{array}{l}\text { Intention-to-treat analysis performed? } \\
\text { Function }\end{array}$ & Unclear & Not applicable, no function outcome reported. \\
\hline \begin{tabular}{l} 
No funding by commercial organisation? \\
\hline
\end{tabular} & Unclear & No information provided. \\
\hline
\end{tabular}

\section{Zautra 2005}

\begin{tabular}{|c|c|c|}
\hline Methods & \multicolumn{2}{|c|}{$\begin{array}{l}\text { Randomised controlled trial } \\
\text { 2-arm parallel group design } \\
\text { Trial duration: } 13 \text { weeks } \\
\text { Multicentre trial with } 9 \text { centres } \\
\text { No power calculation reported }\end{array}$} \\
\hline Participants & \multicolumn{2}{|c|}{$\begin{array}{l}107 \text { patients were randomised } \\
104 \text { patients with knee osteoarthritis were reported at baseline } \\
\text { Number of females: } 76 \text { of } 104(73 \%) \\
\text { Average age: } 63 \text { years }\end{array}$} \\
\hline Interventions & \multicolumn{2}{|c|}{$\begin{array}{l}\text { Experimental intervention } \\
\text { Oral oxycodone (Oxycontin), 10mg twice daily } \\
\text { Control intervention } \\
\text { Placebo, twice daily } \\
\text { Treatment duration: } 13 \text { weeks } \\
\text { Analgesics other than study drugs allowed, but it was unclear whether intake was similar } \\
\text { between groups }\end{array}$} \\
\hline Outcomes & \multicolumn{2}{|c|}{$\begin{array}{l}\text { Extracted pain outcome: global pain after } 13 \text { weeks } \\
\text { No function outcome reported } \\
\text { Primary outcome: coping efficacy and arthritis helplessness }\end{array}$} \\
\hline \multicolumn{3}{|l|}{ Notes } \\
\hline \multicolumn{3}{|l|}{ Risk of bias } \\
\hline Item & Authors' judgement & Description \\
\hline Adequate sequence generation? & Unclear & No information provided. \\
\hline Allocation concealment? & Yes & \\
\hline Described as double-blind? & Yes & \\
\hline
\end{tabular}


Zautra 2005 (Continued)

\begin{tabular}{|c|c|c|}
\hline Blinding of patients? & Yes & \\
\hline Blinding of physicians? & Yes & \\
\hline Blinding of outcome assessors? & Yes & \\
\hline $\begin{array}{l}\text { Interventions reported as indistinguish- } \\
\text { able? }\end{array}$ & Yes & \\
\hline Double-dummy technique used? & No & \\
\hline $\begin{array}{l}\text { Intention-to-treat analysis performed? } \\
\text { Pain }\end{array}$ & No & $\begin{array}{l}1 \text { of } 56 \text { patients }(1.8 \%) \text { excluded in experimental group, } 2 \text { of } 51 \\
\text { patients }(3.9 \%) \text { excluded in control group. }\end{array}$ \\
\hline $\begin{array}{l}\text { Intention-to-treat analysis performed? } \\
\text { Function }\end{array}$ & Unclear & Not applicable, no function outcome reported. \\
\hline No funding by commercial organisation? & No & Sponsor: Purdue Pharma \\
\hline
\end{tabular}


Characteristics of excluded studies [ordered by study ID]

\begin{tabular}{|c|c|}
\hline Adams 2006 & Only active control interventions. \\
\hline Andrei 1984 & Percentage of patients with knee or hip osteoarthritis $17 \%(5 / 30)$. \\
\hline Boureau 1990 & Only active control interventions. \\
\hline Brooks 1982 & Percentage of patients with osteoarthritis $50 \%$, no information about joints involved. \\
\hline Burch 2004 & No randomised controlled trial. \\
\hline Caldwell 1999 & Percentage of patients with knee or hip osteoarthritis likely to be below $50 \%$. \\
\hline Choquette 2008 & No randomised controlled trial. \\
\hline Doak 1992 & Crossover trial providing pooled results only. \\
\hline Fancourt 1984 & $\begin{array}{l}\text { Mixed population of rheumatoid arthritis and osteoarthritis, no information about number of patients with } \\
\text { osteoarthritis. }\end{array}$ \\
\hline Gazi 2005 & Only active control interventions. \\
\hline Hale 2007 & Only active control interventions. \\
\hline Le Loet 2005 & Not randomised controlled trial. \\
\hline McIlwain 2005 & Not randomised controlled trial. \\
\hline Mitchell 1984 & $\begin{array}{l}\text { Mixed population of rheumatoid arthritis and osteoarthritis, no information about number of patients with } \\
\text { osteoarthritis. }\end{array}$ \\
\hline Neubauer 1983 & Percentage of patients with osteoarthritis $15 \%(5 / 33)$. \\
\hline Rosenthal 2007 & Not randomised controlled trial. \\
\hline Roth 2000 & Percentage of patients with knee or hip osteoarthritis likely to be below $50 \%$. \\
\hline Salzman 1983 & Only active control interventions. \\
\hline Tassain 2003 & Percentage of patients with osteoarthritis $7 \%(2 / 28)$. \\
\hline Torres 2001 & Not randomised controlled trial. \\
\hline Vignon 1999 & Comparison of combination of dextropropoxyphene, acetaminophen, and caffeine with placebo. \\
\hline
\end{tabular}




\section{(Continued)}

Vlok 1987

Wallace 1994

Wang 1965
Crossover trial providing pooled results only.

Crossover trial providing pooled results only.

Percentage of patients with osteoarthritis 6\% (2/34). 
Characteristics of studies awaiting assessment [ordered by study ID]

\section{Kroner 1991}

\begin{tabular}{ll}
\hline Methods & $\begin{array}{l}\text { Randomised controlled trial } \\
\text { 2-arm parallel group design } \\
\text { Trial duration: } 3 \text { weeks } \\
\text { Multicentre trial }\end{array}$ \\
\hline Participants & $\begin{array}{l}\text { 131 patients with hip osteoarthritis were reported at baseline } \\
\text { Number of females: } 70 \text { of } 131(53 \%)\end{array}$ \\
\hline Interventions & $\begin{array}{l}\text { Experimental intervention } \\
\text { Codeine } 30 \mathrm{mg} \text { plus paracetamol 500mg } \\
\text { Control intervention } \\
\text { Paracetamol } 500 \mathrm{mg} \\
\text { Treatment duration: } 3 \text { weeks }\end{array}$ \\
\hline Outcomes & $\begin{array}{l}\text { Assessed efficacy outcomes: pain intensity, pain relief, patient's evaluation of the effect of treatment } \\
\text { Assessed safety outcomes: number of patients withdrawn due to adverse events, serious adverse events }\end{array}$ \\
\hline Notes & \begin{tabular}{l} 
Insufficient data provided in published abstract, no full-text article available. Awaiting author response. \\
\hline
\end{tabular}
\end{tabular}


DATA AND ANALYSES

Comparison 1. Opioids versus placebo

\begin{tabular}{|c|c|c|c|c|}
\hline Outcome or subgroup title & $\begin{array}{l}\text { No. of } \\
\text { studies }\end{array}$ & $\begin{array}{l}\text { No. of } \\
\text { participants }\end{array}$ & Statistical method & Effect size \\
\hline 1 Pain & 10 & 2268 & Std. Mean Difference (Random, 95\% CI) & $-0.36[-0.47,-0.26]$ \\
\hline 1.1 Codeine & 3 & 179 & Std. Mean Difference (Random, 95\% CI) & $-0.51[-1.01,-0.01]$ \\
\hline 1.2 Fentanyl & 1 & 399 & Std. Mean Difference (Random, 95\% CI) & $-0.22[-0.42,-0.03]$ \\
\hline 1.3 Morphine & 1 & 295 & Std. Mean Difference (Random, 95\% CI) & $-0.32[-0.59,-0.06]$ \\
\hline 1.4 Oxycodone & 4 & 750 & Std. Mean Difference (Random, 95\% CI) & $-0.42[-0.65,-0.20]$ \\
\hline 1.5 Oxymorphone & 2 & 645 & Std. Mean Difference (Random, 95\% CI) & $-0.39[-0.58,-0.21]$ \\
\hline 2 Function & 7 & 1794 & Std. Mean Difference (Random, 95\% CI) & $-0.33[-0.45,-0.21]$ \\
\hline 2.1 Codeine & 2 & 169 & Std. Mean Difference (Random, 95\% CI) & $-0.42[-0.74,-0.10]$ \\
\hline 2.2 Fentanyl & 1 & 399 & Std. Mean Difference (Random, 95\% CI) & $-0.28[-0.48,-0.09]$ \\
\hline 2.3 Morphine & 1 & 295 & Std. Mean Difference (Random, 95\% CI) & $-0.29[-0.56,-0.03]$ \\
\hline 2.4 Oxycodone & 2 & 286 & Std. Mean Difference (Random, 95\% CI) & $-0.44[-1.12,0.24]$ \\
\hline 2.5 Oxymorphone & 2 & 645 & Std. Mean Difference (Random, 95\% CI) & $-0.32[-0.50,-0.13]$ \\
\hline $\begin{array}{l}3 \text { Number of patients experiencing } \\
\text { any adverse event }\end{array}$ & 4 & 1080 & Risk Ratio (IV, Random, 95\% CI) & $1.55[1.41,1.70]$ \\
\hline 3.1 Codeine & 1 & 66 & Risk Ratio (IV, Random, 95\% CI) & $1.28[0.94,1.75]$ \\
\hline 3.2 Fentanyl & 1 & 416 & Risk Ratio (IV, Random, 95\% CI) & $1.55[1.33,1.81]$ \\
\hline 3.3 Oxycodone & 2 & 294 & Risk Ratio (IV, Random, 95\% CI) & $1.62[1.36,1.92]$ \\
\hline 3.4 Oxymorphone & 1 & 304 & Risk Ratio (IV, Random, 95\% CI) & $1.59[1.28,1.97]$ \\
\hline $\begin{array}{l}4 \text { Number of patients who } \\
\text { withdrew because of adverse } \\
\text { events }\end{array}$ & 10 & 2403 & Risk Ratio (IV, Random, 95\% CI) & $4.05[3.06,5.38]$ \\
\hline 4.1 Codeine & 3 & 277 & Risk Ratio (IV, Random, 95\% CI) & $3.67[2.16,6.24]$ \\
\hline 4.2 Fentanyl & 1 & 399 & Risk Ratio (IV, Random, 95\% CI) & $2.63[1.64,4.23]$ \\
\hline 4.3 Morphine & 1 & 295 & Risk Ratio (IV, Random, 95\% CI) & $3.49[1.45,8.39]$ \\
\hline 4.4 Oxycodone & 4 & 758 & Risk Ratio (IV, Random, 95\% CI) & $7.75[3.76,15.97]$ \\
\hline 4.5 Oxymorphone & 2 & 674 & Risk Ratio (IV, Random, 95\% CI) & $5.32[2.93,9.68]$ \\
\hline $\begin{array}{l}5 \text { Number of patients experiencing } \\
\text { any serious adverse event }\end{array}$ & 3 & 681 & Risk Ratio (IV, Random, 95\% CI) & $3.35[0.83,13.56]$ \\
\hline 5.1 Codeine & 1 & 158 & Risk Ratio (IV, Random, 95\% CI) & Not estimable \\
\hline 5.2 Fentanyl & 1 & 416 & Risk Ratio (IV, Random, 95\% CI) & $2.78[0.57,13.60]$ \\
\hline 5.3 Oxycodone & 1 & 107 & Risk Ratio (IV, Random, 95\% CI) & $6.39[0.34,120.71]$ \\
\hline 6 Withdrawal symptoms & 1 & 499 & Std. Mean Difference (IV, Fixed, 95\% CI) & $0.60[0.42,0.79]$ \\
\hline
\end{tabular}




\section{Analysis I.I. Comparison I Opioids versus placebo, Outcome I Pain.}

Review: Oral or transdermal opioids for osteoarthritis of the knee or hip

Comparison: I Opioids versus placebo

Outcome: I Pain

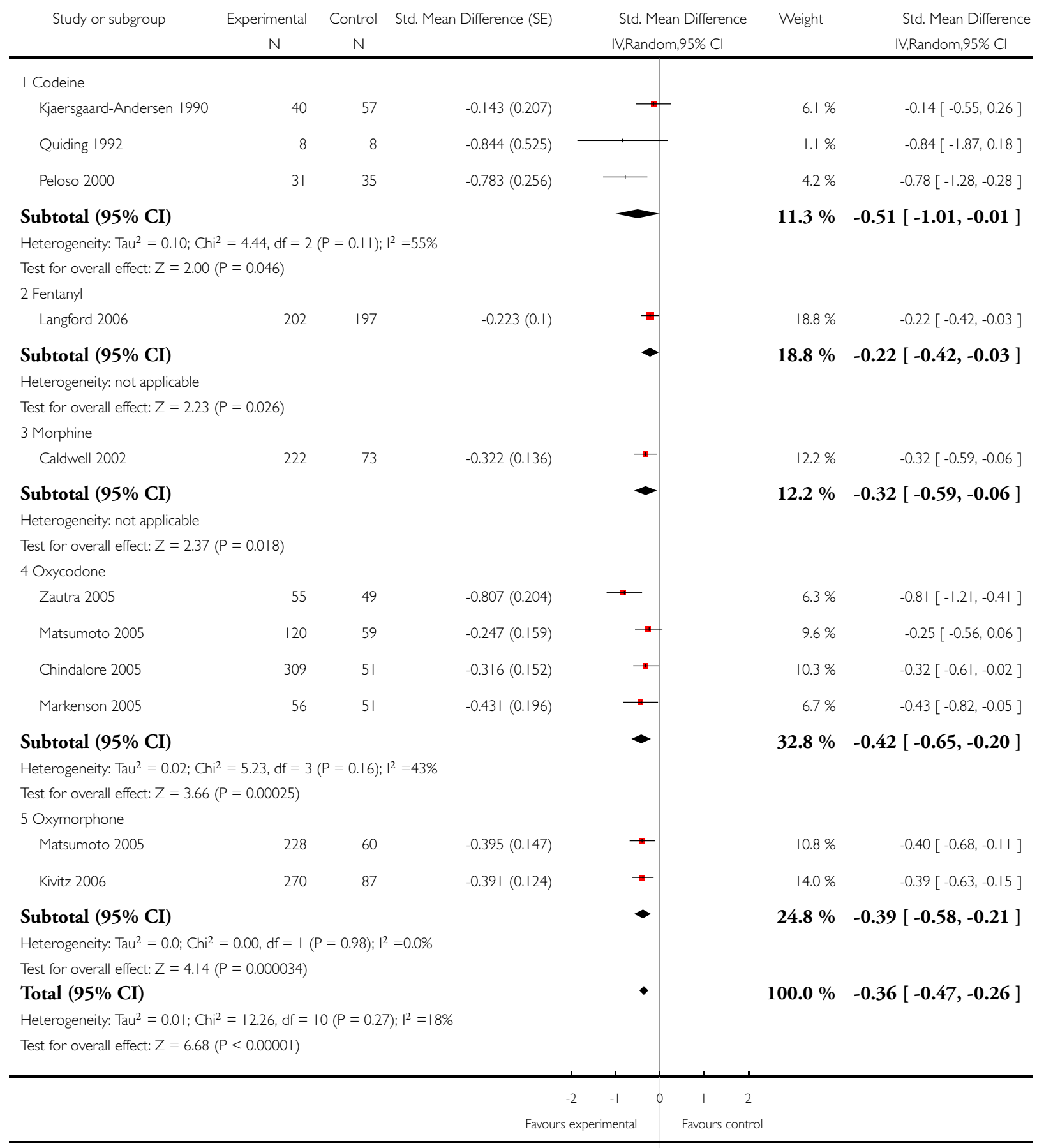

Oral or transdermal opioids for osteoarthritis of the knee or hip (Review) 


\section{Analysis I.2. Comparison I Opioids versus placebo, Outcome 2 Function.}

Review: Oral or transdermal opioids for osteoarthritis of the knee or hip

Comparison: I Opioids versus placebo

Outcome: 2 Function

\begin{tabular}{|c|c|c|c|c|c|c|c|}
\hline Study or subgroup & $\begin{array}{c}\text { Experimental } \\
\mathrm{N}\end{array}$ & $\begin{array}{c}\text { Control } \\
\mathrm{N}\end{array}$ & Std. Mean Difference (SE) & $\begin{array}{r}\text { Std. M } \\
\text { IV,Rand }\end{array}$ & $\begin{array}{l}\text { lean Difference } \\
\text { dom,95\% Cl }\end{array}$ & Weight & $\begin{array}{l}\text { Std. Mean Difference } \\
\text { IV,Random,95\% Cl }\end{array}$ \\
\hline I Codeine & & & & & & & \\
\hline Kjaersgaard-Andersen 1990 & 43 & 60 & $-0.288(0.201)$ & $\square$ & + & $8.0 \%$ & $-0.29[-0.68,0.11]$ \\
\hline Peloso 2000 & 31 & 35 & $-0.621(0.253)$ & $\rightleftarrows$ & & $5.3 \%$ & $-0.62[-1.12,-0.13]$ \\
\hline Subtotal (95\% CI) & & & & & & $13.3 \%$ & $-0.42[-0.74,-0.10]$ \\
\hline Heterogeneity: $\operatorname{Tau}^{2}=0.00 ; \mathrm{Ch}$ & $=1.06, \mathrm{df}=1$ & $P=0.30)$ & $1^{2}=6 \%$ & & & & \\
\hline Test for overall effect: $Z=2.58$ & $P=0.010)$ & & & & & & \\
\hline 2 Fentanyl & & & & & & & \\
\hline Langford 2006 & 202 & 197 & $-0.283(0.101)$ & $\longrightarrow$ & & $21.8 \%$ & $-0.28[-0.48,-0.09]$ \\
\hline Subtotal (95\% CI) & & & & & & $21.8 \%$ & $-0.28[-0.48,-0.09]$ \\
\hline Heterogeneity: not applicable & & & & & & & \\
\hline Test for overall effect: $Z=2.80$ & $P=0.0051)$ & & & & & & \\
\hline 3 Morphine & & & & & & & \\
\hline Caldwell 2002 & 222 & 73 & $-0.29 \mid(0.135)$ & & & $15.0 \%$ & $-0.29[-0.56,-0.03]$ \\
\hline Subtotal (95\% CI) & & & & & & $15.0 \%$ & $-0.29[-0.56,-0.03]$ \\
\hline Heterogeneity: not applicable & & & & & & & \\
\hline Test for overall effect: $Z=2.16$ & $P=0.03 \mid)$ & & & & & & \\
\hline 4 Oxycodone & & & & & & & \\
\hline Matsumoto 2005 & 120 & 59 & $-0.107(0.159)$ & & - & $11.7 \%$ & $-0.11[-0.42,0.20]$ \\
\hline Markenson 2005 & 56 & 51 & $-0.798(0.201)$ & $\longleftarrow$ & & $8.0 \%$ & $-0.80[-1.19,-0.40]$ \\
\hline Subtotal (95\% CI) & & & & & & $19.7 \%$ & $-0.44[-1.12,0.24]$ \\
\hline Heterogeneity: $\operatorname{Tau}^{2}=0.21 ; \mathrm{Ch}$ & $=7.27, \mathrm{df}=1$ & $P=0.01)$ & $\left.\right|^{2}=86 \%$ & & & & \\
\hline Test for overall effect: $Z=1.28$ & $P=0.20)$ & & & & & & \\
\hline 5 Oxymorphone & & & & & & & \\
\hline Matsumoto 2005 & 228 & 60 & $-0.273(0.146)$ & & & $13.3 \%$ & $-0.27[-0.56,0.01]$ \\
\hline Kivitz 2006 & 270 & 87 & $-0.353(0.124)$ & $\square$ & & $16.8 \%$ & $-0.35[-0.60,-0.11]$ \\
\hline Subtotal (95\% CI) & & & & & & $30.2 \%$ & $-0.32[-0.50,-0.13]$ \\
\hline Heterogeneity: $\mathrm{Tau}^{2}=0.0 ; \mathrm{Chi}^{2}$ & $=0.17, \mathrm{df}=1$ & $=0.68) ; 1^{2}$ & $2=0.0 \%$ & & & & \\
\hline Test for overall effect: $Z=3.38$ & $P=0.00072)$ & & & & & & \\
\hline Total $(95 \% \mathrm{CI})$ & & & & $<$ & & $100.0 \%$ & $-0.33[-0.45,-0.21]$ \\
\hline Heterogeneity: $\operatorname{Tau}^{2}=0.01 ; \mathrm{Ch}$ & $=9.23, \mathrm{df}=7$ & $P=0.24)$ & $P^{2}=24 \%$ & & & & \\
\hline Test for overall effect: $Z=5.41$ & $P<0.0000$ I) & & & & & & \\
\hline & & & & -0.5 & 0.5 & & \\
\hline & & & Favour & s experimental & Favours contrc & & \\
\hline
\end{tabular}




\section{Analysis I.3. Comparison I Opioids versus placebo, Outcome 3 Number of patients experiencing any}

adverse event.

Review: Oral or transdermal opioids for osteoarthritis of the knee or hip

Comparison: I Opioids versus placebo

Outcome: 3 Number of patients experiencing any adverse event

Study or subgroup $\quad$ Experimental $\quad$ Control $\quad$ Risk Ratio $\quad$ Weight

$n / \mathrm{N} \quad \mathrm{n} / \mathrm{N}$

IV,Random,95\% Cl

| Codeine
Peloso $2000 \quad$ 25/31 22/35

Subtotal (95\% CI)

31

35

$\mathrm{V}$, Random,95\% Cl

Total events: 25 (Experimental), 22 (Control)

Heterogeneity: not applicable

Test for overall effect: $Z=1.59(P=0.11)$

2 Fentanyl

$\begin{array}{lll}\text { Langford } 2006 & \text { 169/216 }\end{array}$

$216 \quad 200$

$38.8 \%$

$1.55[1.33,1.81]$

Subtotal (95\% CI)

$38.8 \%$

$1.55[1.33,1.81]$

Total events: 169 (Experimental), 101 (Control)

Heterogeneity: not applicable

Test for overall effect: $Z=5.57(P<0.0000 \mathrm{I})$

3 Oxycodone

$\begin{array}{lrr}\text { Matsumoto } 2005 & 110 / 125 & 35 / 62 \\ \text { Markenson 2005 } & 52 / 56 & 28 / 51\end{array}$

Subtotal (95\% CI)

181

113

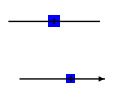

$17.7 \%$

$1.56[1.24,1.96]$

$13.7 \%$

$1.69[1.31,2.19]$

Total events: 162 (Experimental), 63 (Control)

Heterogeneity: $\mathrm{Tau}^{2}=0.0 ; \mathrm{Chi}^{2}=0.2 \mathrm{I}, \mathrm{df}=\mathrm{I}(\mathrm{P}=0.64) ; \mathrm{I}^{2}=0.0 \%$

Test for overall effect: $Z=5.49(P<0.0000 I)$

4 Oxymorphone

Matsumoto 2005

$223 / 242$

$36 / 62$

Subtotal (95\% CI)

242

62

$20.0 \%$

$1.59[1.28,1.97]$

Total events: 223 (Experimental), 36 (Control)

Heterogeneity: not applicable

Test for overall effect: $Z=4.22(P=0.000025)$

Total (95\% CI)

670

410

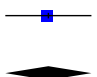

$20.0 \%$

$1.59[1.28,1.97]$

Total events: 579 (Experimental), 222 (Control)

Heterogeneity: $\operatorname{Tau}^{2}=0.0 ; \mathrm{Chi}^{2}=1.94, \mathrm{df}=4(\mathrm{P}=0.75) ; \mathrm{I}^{2}=0.0 \%$

Test for overall effect: $Z=8.93(P<0.0000 I)$ 
Analysis I.4. Comparison I Opioids versus placebo, Outcome 4 Number of patients who withdrew because of adverse events.

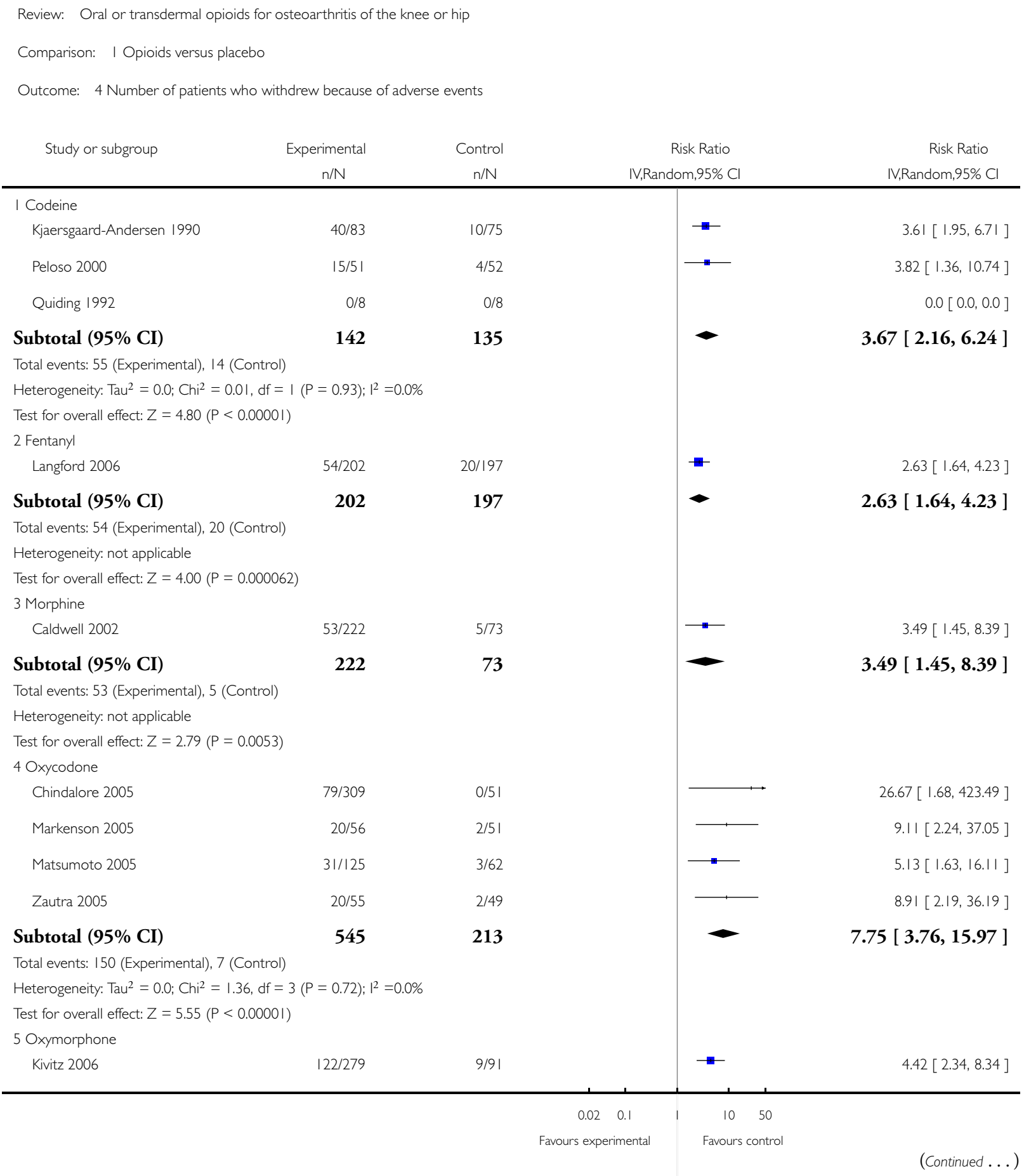




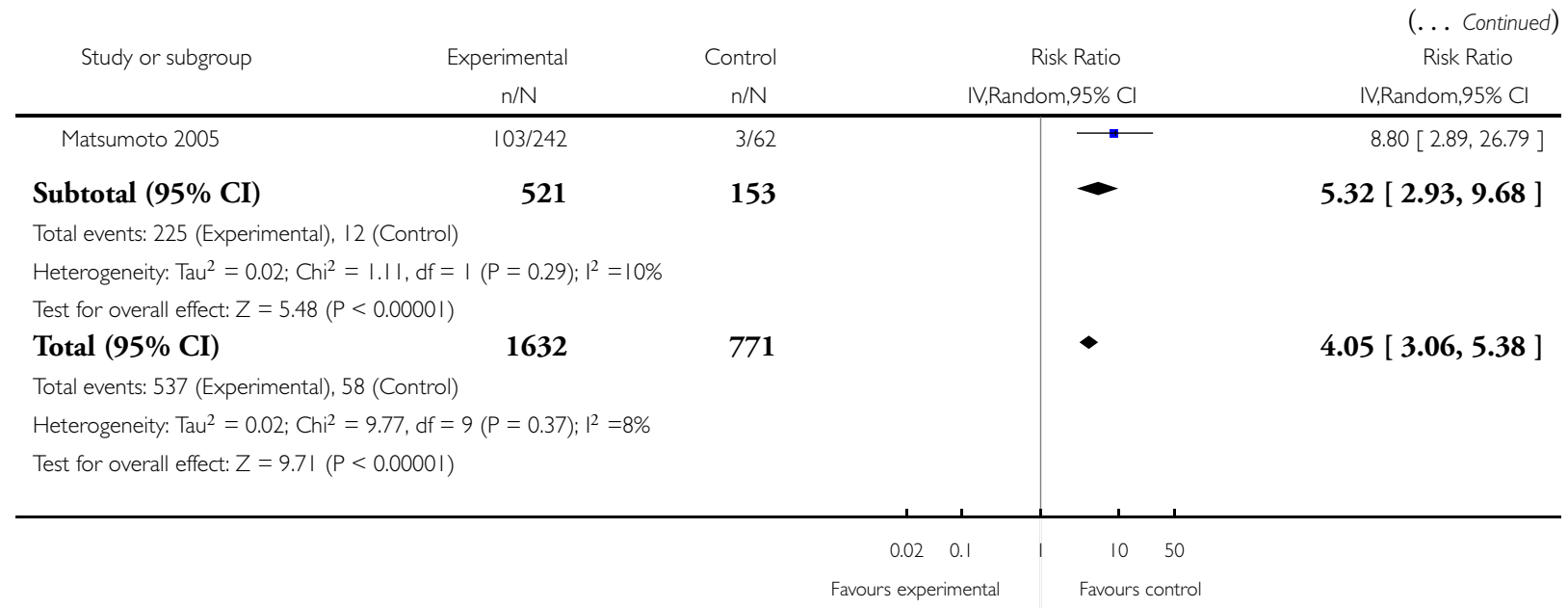

\section{Analysis I.5. Comparison I Opioids versus placebo, Outcome 5 Number of patients experiencing any} serious adverse event.

Review: Oral or transdermal opioids for osteoarthritis of the knee or hip

Comparison: I Opioids versus placebo

Outcome: 5 Number of patients experiencing any serious adverse event

\begin{tabular}{|c|c|c|c|c|c|}
\hline Study or subgroup & $\begin{array}{c}\text { Experimental } \\
n / N\end{array}$ & $\begin{array}{c}\text { Control } \\
\mathrm{n} / \mathrm{N}\end{array}$ & & $\begin{array}{c}\text { Risk Ratio } \\
\text { IV,Random,95\% Cl }\end{array}$ & $\begin{array}{c}\text { Risk Ratio } \\
\text { IV,Random,95\% Cl }\end{array}$ \\
\hline \multicolumn{6}{|l|}{ I Codeine } \\
\hline Kjaersgaard-Andersen 1990 & 0/83 & 0/75 & & & $0.0[0.0,0.0]$ \\
\hline Subtotal $(95 \% \mathrm{CI})$ & 83 & 75 & & & $0.0[0.0,0.0]$ \\
\hline \multicolumn{6}{|c|}{ Total events: 0 (Experimental), 0 (Control) } \\
\hline \multicolumn{6}{|c|}{ Heterogeneity: not applicable } \\
\hline \multicolumn{6}{|c|}{ Test for overall effect: $Z=0.0(P<0.0000 \mathrm{I})$} \\
\hline \multicolumn{6}{|l|}{2 Fentanyl } \\
\hline Langford 2006 & $6 / 216$ & $2 / 200$ & & $\square$ & $2.78[0.57,13.60]$ \\
\hline Subtotal $(95 \% \mathrm{CI})$ & 216 & 200 & & - & $2.78[0.57,13.60]$ \\
\hline \multicolumn{6}{|c|}{ Total events: 6 (Experimental), 2 (Control) } \\
\hline \multicolumn{6}{|c|}{ Heterogeneity: not applicable } \\
\hline \multicolumn{6}{|c|}{ Test for overall effect: $Z=1.26(P=0.21)$} \\
\hline \multicolumn{6}{|l|}{3 Oxycodone } \\
\hline Markenson 2005 & $3 / 56$ & $0 / 51$ & & 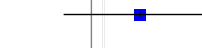 & $6.39[0.34,120.71]$ \\
\hline \multirow[t]{3}{*}{ Subtotal $(95 \% \mathrm{CI})$} & 56 & 51 & & - & $6.39[0.34,120.71]$ \\
\hline & & & 0.005 & 0.1 & 200 \\
\hline & & & Favours expe & Favours ce & ontrol \\
\hline
\end{tabular}




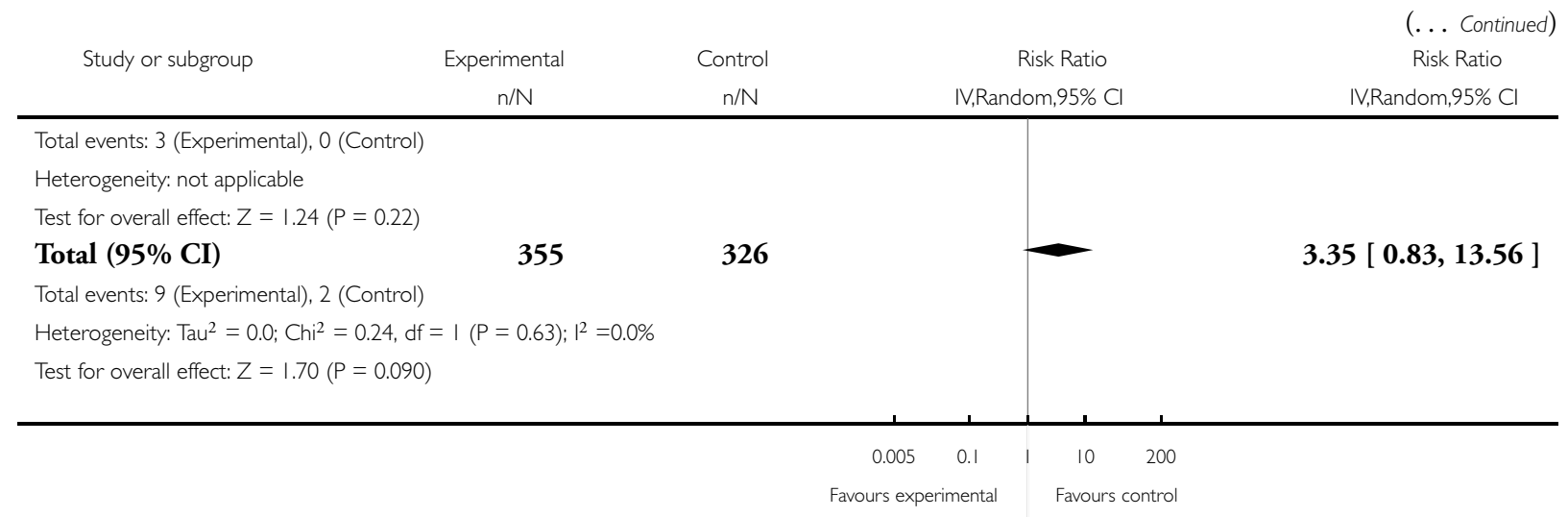

Analysis I.6. Comparison I Opioids versus placebo, Outcome 6 Withdrawal symptoms.

Review: Oral or transdermal opioids for osteoarthritis of the knee or hip

Comparison: I Opioids versus placebo

Outcome: 6 Withdrawal symptoms

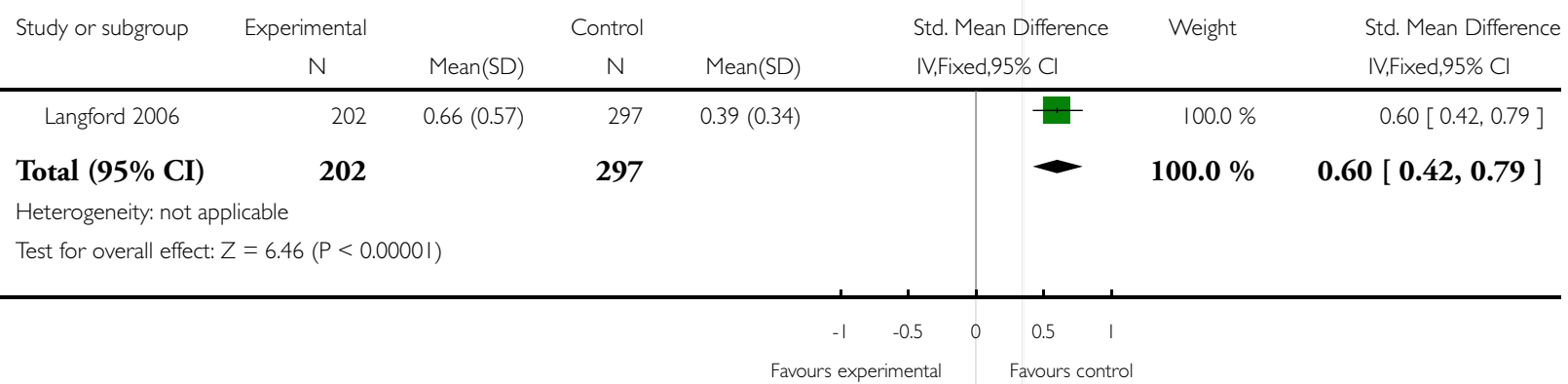




\section{A P P E N D I C E S}

Appendix I. MEDLINE, EMBASE and CINAHL search strategy

\begin{tabular}{|c|c|c|}
\hline OVID MEDLINE & OVID EMBASE & CINAHL through EBSCOhost \\
\hline $\begin{array}{l}\text { Search terms for design } \\
\text { 1. randomized controlled trial.pt. } \\
\text { 2. controlled clinical trial.pt. } \\
\text { 3. randomized controlled trial.sh. } \\
\text { 4. random allocation.sh. } \\
\text { 5. double blind method.sh. } \\
\text { 6. single blind method.sh. } \\
\text { 7. clinical trial.pt. } \\
\text { 8. exp clinical trial/ } \\
\text { 9. (clin } \$ \text { adj } 25 \text { trial } \$ \text { ).ti,ab. } \\
\text { 10. ((singl } \$ \text { or doubl\$ or trebl\$ or tripl\$) } \\
\text { adj25 (blind } \$ \text { or mask } \$) \text { ).ti,ab. } \\
\text { 11. placebos.sh. } \\
\text { 12. placebo } \$ . t i, a b . \\
\text { 13. random\$.ti,ab. } \\
\text { 14. research design.sh. } \\
\text { 15. comparative study.sh. } \\
\text { 16. exp evaluation studies/ } \\
\text { 17. follow up studies.sh. } \\
\text { 18. prospective studies.sh. } \\
\text { 19. (control } \$ \text { or prospectiv } \$ \text { or volun- } \\
\text { teer } \$ \text { ).ti,ab. }\end{array}$ & $\begin{array}{l}\text { Search terms for design } \\
\text { 1. randomized controlled trial.sh. } \\
\text { 2. randomization.sh. } \\
\text { 3. double blind procedure.sh. } \\
\text { 4. single blind procedure.sh. } \\
\text { 5. exp clinical trials/ } \\
\text { 6. (clin } \$ \text { adj25 trial\$).ti,ab. } \\
\text { 7. ((singl\$ or doubl\$ or trebl\$ or tripl\$) } \\
\text { adj25 (blind } \$ \text { or mask\$)).ti,ab. } \\
\text { 8. placebo.sh. } \\
\text { 9. placebo } \$ . t i, a b . \\
\text { 10. random\$.ti,ab. } \\
\text { 11. methodology.sh. } \\
\text { 12. comparative study.sh. } \\
\text { 13. exp evaluation studies/ } \\
\text { 14. follow up.sh. } \\
\text { 15. prospective study.sh. } \\
\text { 16. (control\$ or prospectiv\$ or volun- } \\
\text { teer\$).ti,ab. }\end{array}$ & 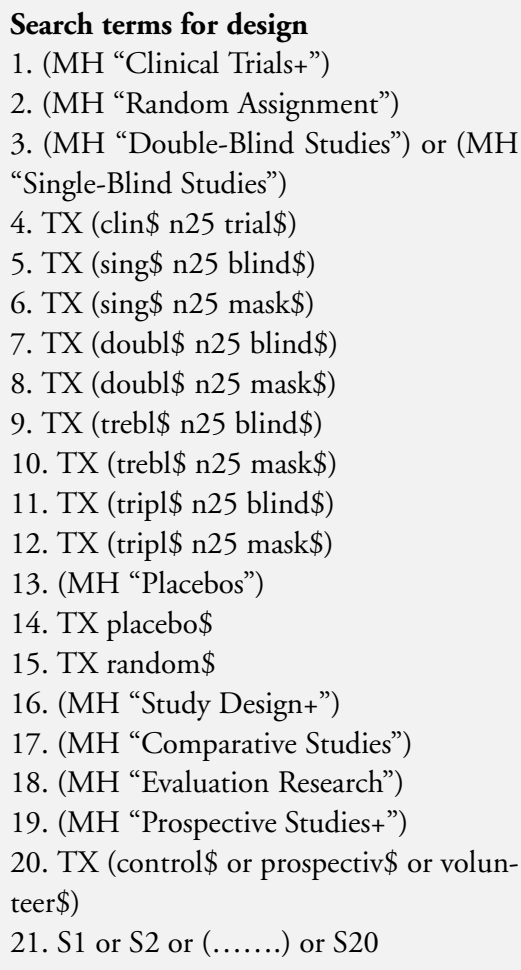 \\
\hline $\begin{array}{l}\text { Search terms for Osteoarthritis } \\
\text { 20. exp osteoarthritis/ } \\
\text { 21. osteoarthriti } \$ . t i, a b, s h . \\
\text { 22. osteoarthro\$.ti,ab,sh. } \\
\text { 23. gonarthriti } \$ . t i, a b, s h . \\
\text { 24. gonarthro\$.ti,ab,sh. } \\
\text { 25. coxarthriti\$.ti,ab,sh. } \\
\text { 26. coxarthro\$.ti,ab,sh. } \\
\text { 27. arthros\$.ti,ab. } \\
\text { 28. arthrot\$.ti,ab. } \\
\text { 29. ((knee\$ or hip\$ or joint\$) adj3 (pain\$ } \\
\text { or ach\$ or discomfort\$)).ti,ab. } \\
\text { 30. ((knee\$ or hip\$ or joint\$) adj3 } \\
\text { stiff\$).ti,ab. }\end{array}$ & 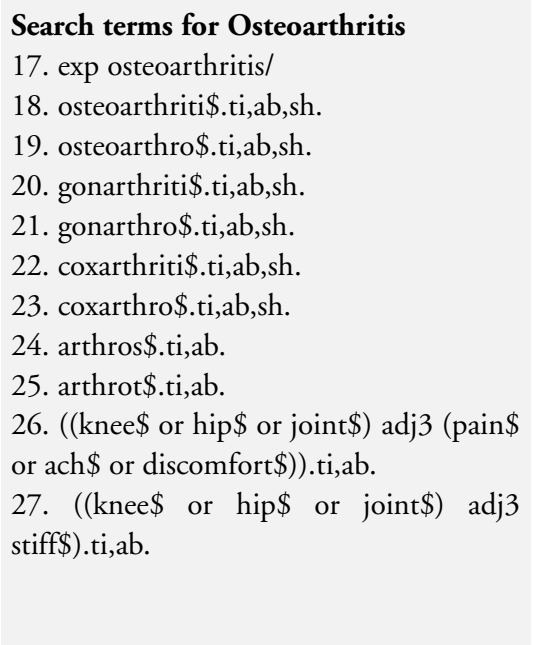 & 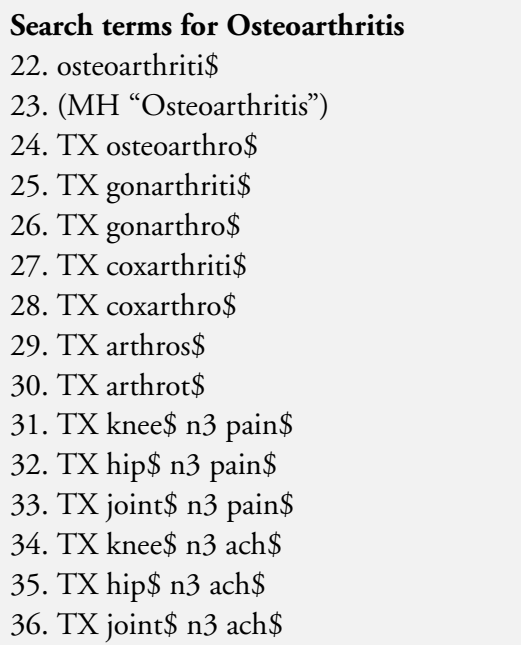 \\
\hline
\end{tabular}




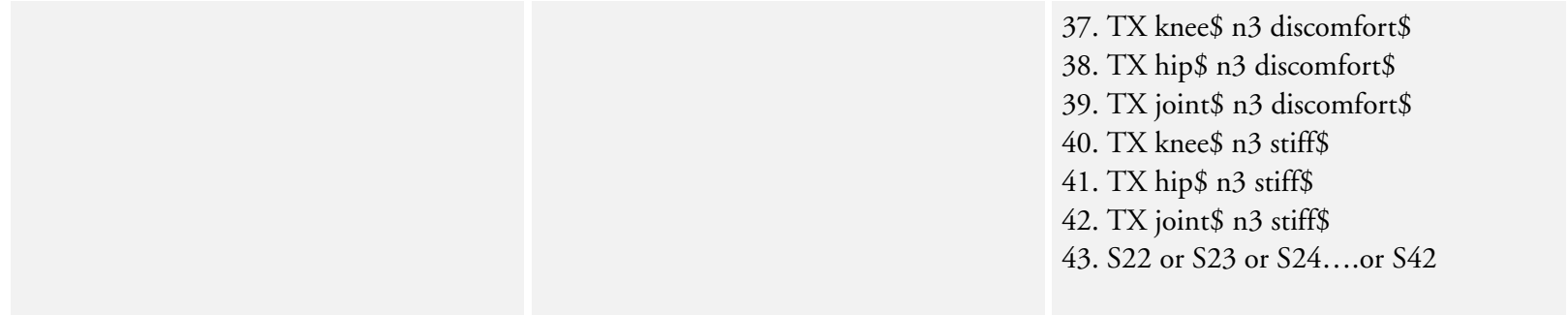

\section{Search terms for Opioids}

31. exp Analgesics, Opioid/

32. exp Narcotics/

33. acetyldihydrocodeine.tw.

34. alfentanil.tw.

35. allylprodine.tw.

36. alphamethylfentanyl.tw.

37. alphaprodine.tw.

38. benzylmorphine.tw.

39. betaprodine.tw.

40. bezitriamide.tw.

41. buprenorphine.tw.

42. butorphanol.tw.

43. bremazocine.tw.

44. carfentan\$.tw.

45. codeine.tw.

46. contin.tw.

47. dextromoramide.tw.

48. dextropropoxyphene.tw.

49. dezocine.tw.

50. diacetylmorphine.tw.

51. diamorphine.tw.

52. dihydrocodeine.tw.

53. dihydromorphine.tw.

54. dihydromorphone.tw.

55. diphenoxylate.tw.

56. dipipanone.tw.

57. enadoline.tw.

58. ethylketazocine.tw.

59. ethylmorphine.tw.

60. etonitazene.tw.

61. etorphine.tw.

62. fentanyl.tw.

63. heroin.tw.

64. hydrocodone.tw.

65. hydromorphin\$.tw.

66. hydromorphone.tw.

\section{Search terms for Opioids}

28. exp Analgesics, Opioid/

29. exp Narcotic Analgesic Agent/

30. acetyldihydrocodeine.tw.

31. alfentanil.tw.

32. allylprodine.tw.

33. alphamethylfentanyl.tw.

34. alphaprodine.tw.

35. benzylmorphine.tw.

36. betaprodine.tw.

37. bezitriamide.tw.

38. buprenorphine.tw.

39. butorphanol.tw.

40. bremazocine.tw.

41. carfentan\$.tw.

42. codeine.tw.

43. contin.tw.

44. dextromoramide.tw.

45. dextropropoxyphene.tw.

46. dezocine.tw.

47. diacetylmorphine.tw.

48. diamorphine.tw.

49. dihydrocodeine.tw.

50. dihydromorphine.tw.

51. dihydromorphone.tw.

52. diphenoxylate.tw.

53. dipipanone.tw.

54. enadoline.tw.

55. ethylketazocine.tw.

56. ethylmorphine.tw.

57. etonitazene.tw.

58. etorphine.tw.

59. fentanyl.tw.

60. heroin.tw.

61. hydrocodone.tw.

62. hydromorphin\$.tw.

63. hydromorphone.tw.

\section{Search terms for Opioids}

44. MH "Analgesics, Opioid"

45. MH "Narcotics"

46. TX acetyldihydrocodeine

47. TX alfentanil

48. TX allylprodine

49. TX alphamethylfentanyl

50. TX alphaprodine

51. TX benzylmorphine

52. TX betaprodine

53. TX bezitriamide

54. TX buprenorphine

55. TX butorphanol

56. TX bremazocine

57. TX carfentan\$

58. TX codeine

58. TX contin

60. TX dextromoramide

61. TX dextropropoxyphene

62. TX dezocine

63. TX diacetylmorphine

64. TX diamorphine

65. TX dihydrocodeine

66. TX dihydromorphine

67. TX dihydromorphone

68. TX diphenoxylate

69. TX dipipanone

70. TX enadoline

71. TX ethylketazocine

72. TX ethylmorphine

73. TX etonitazene

74. TX etorphine

75. TX fentanyl

76. TX heroin

77. TX hydrocodone

78. TX hydromorphin\$

79. TX hydromorphone 


\section{7. ketazocine.tw.}

68. ketobemidone.tw.

69. lefetamine.tw.

70. levomethadon.tw.

71. levomethadyl.tw.

72. levomethorphan\$.tw.

73. levorphanol.tw.

74. loperamide.tw.

75. meperidine.tw.

76. meptazinol.tw.

77. methadone.tw.

78. methadyl.tw.

79. methylmorphine.tw.

80. morphin\$.tw.

81. nalbuphine.tw.

82. narcotic\$.tw.

83. nicocodeine.tw.

84. nicomorphine.tw.

85. normorphine.tw.

86. noscapin\$.tw.

87. ohmefentanyl.tw.

88. opiate\$.tw.

89. opioid\$.tw.

90. opium.tw.

91. oripavine.tw.

92. oxycodone.tw.

93. oxycontin.tw.

94. oxymorphone.tw.

95. papaveretum.tw.

96. papaverin.tw.

97. pentazocine.tw.

98. percocet.tw.

99. peronine.tw.

100. pethidine.tw.

101. phenazocine.tw.

102. phencyclidine.tw.

103. pholcodine.tw.

104. piritramid\$.tw.

105. prodine.tw.

106. promedol.tw.

107. propoxyphene.tw.

108. remifentanil.tw.

109. sufentanil.tw.

110. tapentadol.tw.

111. thebaine.tw.

112. tilidine.tw.
64. ketazocine.tw.

65. ketobemidone.tw.

66. lefetamine.tw.

67. levomethadon.tw.

68. levomethadyl.tw.

69. levomethorphan\$.tw.

70. levorphanol.tw.

71. loperamide.tw.

72. meperidine.tw.

73. meptazinol.tw.

74. methadone.tw.

75. methadyl.tw.

76. methylmorphine.tw.

77. morphin\$.tw.

78. nalbuphine.tw.

79. narcotic\$.tw.

80. nicocodeine.tw.

81. nicomorphine.tw.

82. normorphine.tw.

83. noscapin \$.tw.

84. ohmefentanyl.tw.

85. opiate\$.tw.

86. opioid\$.tw.

87. opium.tw.

88. oripavine.tw.

89. oxycodone.tw.

90. oxycontin.tw.

91. oxymorphone.tw.

92. papaveretum.tw.

93. papaverin.tw.

94. pentazocine.tw.

95. percocet.tw.

96. peronine.tw.

97. pethidine.tw.

98. phenazocine.tw.

99. phencyclidine.tw.

100. pholcodine.tw.

101. piritramid\$.tw.

102. prodine.tw.

103. promedol.tw.

104. propoxyphene.tw.

105. remifentanil.tw.

106. sufentanil.tw.

107. tapentadol.tw.

108. thebaine.tw.

109. tilidine.tw.
80. TX ketazocine

81. TX ketobemidone

82. TX lefetamine

83. TX levomethadon

84. TX levomethadyl

85. TX levomethorphan\$

86. TX levorphanol

87. TX loperamide

88. TX meperidine

89. TX meptazinol

90. TX methadone

91. TX methadyl

92. TX methylmorphine

93. TX morphin\$

94. TX nalbuphine

95. TX narcotic\$

96. TX nicocodeine

97. TX nicomorphine

98. TX normorphine

99. TX noscapin\$

100. TX ohmefentanyl

101. TX opiate\$

102. TX opioid\$

103. TX opium

104. TX oripavine

105. TX oxycodone

106. TX oxycontin

107. TX oxymorphone

108. TX papaveretum

109. TX papaverin

110. TX pentazocine

111. TX percocet

112. TX peronine

113. TX pethidine

114. TX phenazocine

115. TX phencyclidine

116. TX pholcodine

117. TX piritramid\$

118. TX prodine

119. TX promedol

120. TX propoxyphene

121. TX remifentanil

122. TX sufentanil

123. TX tapentadol

124. TX thebaine

125. TX tilidine

126. $S 44$ or $S 45$ or $S 125$ 


\section{Combining terms}

113. or/31-112

114. or/1-19

115. or $/ 20-30$

116. and/113-115

117. animal/

118. animal/ and human/

119. 117 not 118

120. 116 not 119

121. remove duplicates from 120

\section{Combining terms}

110. or/28-109

111. or/1-16

112. or/17-27

113. and/110-112

114. animal/

115. animal/ and human/

116. 114 not 115

117. 113 not 116

118. remove duplicates from 117
Combining terms

127. S21 and S43 and S126 


\section{Appendix 2. CENTRAL search strategy}

\section{CENTRAL}

Search terms for Osteoarthritis

\#1. MeSH descriptor Osteoarthritis explode all trees

\#2. (osteoarthritis* OR osteoarthro* OR gonarthriti* OR gonarthro*

OR coxarthriti* OR coxarthro* OR arthros* OR arthrot* OR

((knee* OR hip* OR joint*) near/3 (pain* OR ach* OR discomfort*))

OR ((knee* OR hip* OR joint* ${ }^{*}$ near/3 stiff*)) in Clinical Trials

Search terms for Opioids

\#3. MeSH descriptor Analgesics, Opioid explode all trees

\#4. MeSH descriptor Narcotics explode all trees

\#5. (acetyldihydrocodeine OR alfentanil OR allylprodine OR alphamethylfentanyl OR alphaprodine OR benzylmorphine OR betaprodine OR bezitriamide OR buprenorphine OR butorphanol OR bremazocine OR carfentan* OR codeine OR contin OR dextromoramide OR dextropropoxyphene OR dezocine OR diacetylmorphine OR diamorphine OR dihydrocodeine OR dihydromorphine OR dihydromorphone OR diphenoxylate OR dipipanone OR enadoline OR ethylketazocine OR ethylmorphine OR etonitazene OR etorphine OR fentanyl OR heroin OR hydrocodone OR hydromorphin* OR hydromorphone OR ketazocine OR ketobemidone OR lefetamine OR levomethadon OR levomethadyl OR levomethorphan* OR levorphanol OR loperamide OR meperidine OR meptazinol OR methadone OR methadyl OR methylmorphine OR morphin* OR nalbuphine OR narcotic* OR nicocodeine OR nicomorphine OR normorphine OR noscapin* OR ohmefentanyl OR opiate* OR opioid* OR opium OR oripavine OR oxycodone OR oxycontin OR oxymorphone OR papaveretum OR papaverin OR pentazocine OR percocet OR peronine OR pethidine OR phenazocine OR phencyclidine OR pholcodine OR piritramid* OR prodine OR promedol OR propoxyphene OR remifentanil OR sufentanil OR tapentadol OR thebaine OR tilidine) in Clinical Trials Combining terms

\#6. (\#1 OR \#2)

\#7. (\#3 OR \#4 OR \#5)

\#8. (\#6 AND \#7) in Clinical Trials

\section{WHAT'S NEW}

Last assessed as up-to-date: 12 May 2008.

13 May 2008 Amended Change in authorship

1 May 2008 Amended CMSG ID C141-R 


\section{H I S T O R Y}

Protocol first published: Issue 2, 2001

Review first published: Issue 4, 2009

\section{CONTRIBUTIONS OFAUTHORS}

Protocol completion: Nüesch, Rutjes, Husni, Jüni

Acquisition of data: Nüesch, Rutjes

Analysis and interpretation of data: Nüesch, Rutjes, Husni, Welch, Jüni

Manuscript preparation: Nüesch, Rutjes, Husni, Welch, Jüni

Statistical analysis: Nüesch, Rutjes, Jüni

Mrs Nüesch and Dr Rutjes contributed equally to this review.

\section{DECLARATIONS OF INTEREST}

None

\section{SOURCES OF SUPPORT}

\section{Internal sources}

- Institute of Social and Preventive Medicine, University or Bern, Switzerland. Intramural grants

\section{External sources}

- Swiss National Science Foundation, Switzerland.

National Research Program 53 on musculoskeletal health (grant numbers 4053-40-104762/3 and 3200-066378)

\section{DIFFERENCES BETWEEN PROTOCOLANDREVIEW}

The cut off to distinguish between short-term and long-term trials was changed from 26 weeks to one month. 